\title{
FACTORS IMPACTING ON CAREER CHOICES OF TECHNIKON STUDENTS FROM PREVIOUSLY DISADVANTAGED HIGH SCHOOLS
}

SIHLE NHLANHLA MBANJWA

Submitted in partial fulfillment of the requirements for the degree of Masters in Educational Psychology, in the School of Education at the University of KwaZulu-Natal 


\section{DECLARATION}

I, Sihle Nhlanhla Mbanjwa, hereby declare that this dissertation entitled "Factors Impacting on Career Choices of Technikon Students from Previously Disadvantaged High Schools", is the result of my own investigation and research and that it has not been submitted in part or in full for any other degree or to any other University.

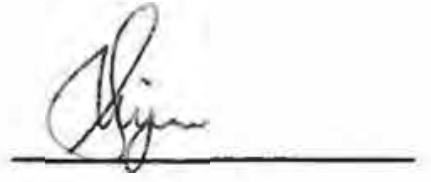

Sihle Nhlanhla Mbanjwa
10 OCTOBER 2005

Date 


\section{DEDICATION}

This dissertation is dedicated to my family: my mother, Thelma Nontuthuzelo Mbanjwa, my sister Sthabisile Philile Mbanjwa, my brother Musawenkosi Mfundo Mbanjwa, and in loving memory of my late father Christopher Bheka Mbanjwa, my late brother Mbuso, my grandparents: the late Esther Khanyisile and Zila Mbanjwa. To uMaZulu (Violet) Ngubo and all my family from my mothers side. Nakuwo onke amaMbanjwa: oGalaza, oMzekwa, oMbuzikazi abasaphila nabangasekho. This is also dedicated to my children "may you all be inspired to study". 


\section{ACKNOWLEDGMENTS}

The author wishes to thank the following people who contributed toward the success of this study:

First and foremost, all praises and thanks to (The most High) God without Whom none of this would have been possible, thank you my Lord.

My family: Super-Mom: Mrs. Nontuthuzelo Thelma Mbanjwa (thanx for being the best mother in the whole world, "I could never have asked for a better mother"), Siblings: my big sister Thabie (for your assistance with the questionnaires and all the support), my young brother Musa (for being a true brother and having the wisdom that God has blessed you with). "I love you guys with my everything."

To my supervisor, Prof $O$. Bojuwoye, for his patience, and guidance.

To Clate Chester, Fathima Haffajee, Nonto Mhlongo, Goodness Khumalo and all the staff (especially Sboniso from the residence) and students (Zola and Ndumi) of DIT (Riverside and Indumiso Campuses) who supported and made this study a success.

To my lecturers, Dr E.A. Chohan, Mrs. E. Clark, and Dr Zaaiboonnisha Naidoo (for your guidance, professionalism and patience, very few are called into the profession and you are some of them, thanks a lot').

A very special thank you to Mr. Henry Muribwathoho, 'thanks for the encouragement, sensitivity and your humane manner of approach, you are the best'.

To Colin Reddy, Anisha Ingrid and Juliet, you guys are real and I'll never forget you'.

To Chand, from the Department of Statistics, 'thank you man'.

To all those who participated in the study 'thank you all for your co-operation and tolerance of my trespassing your lives'.

To, many family and friends who remain unnamed, and whose lives have crisscrossed mine during this period of intellectual growth and maturation, my humble thanks to you all!

Last but not least to my beautiful future wife "Mimi" Bulelwa Ngombane for her undying love, support and friendship, 'I owe you my life'. 


\begin{abstract}
This study reports on the factors that influenced the career choices of 80 first year students at a technikon (University of Technology) in the Kwa-Zulu Natal province of South Africa. The sample consisted 40 males and 40 females who matriculated at previously disadvantaged high schools. A questionnaire was administered to the sample and interviews were conducted with the Psychologist and Career Resources Officer (Librarian) at the technikon.. The main question that guided this investigation was: What are the factors that influenced the career choices of first year technikon students from previously disadvantaged high schools? Career development theories were used as a lens to understand the various factors that influenced their career choices. The review of literature also focused the study on some of the basics that school guidance teachers ought to know about counseling and guidance programmes, in order for them to adequately assist learners in developing their career insights. Results of the study revealed that various factors influenced the career choices of the participants under study, the most dominant being finance, parent/guardians education level, mothers, subject choice, matric points/ results, poor English and media. It was further revealed by the sample in this research that factors such as insufficient information, poor or lack of decision-making skills, problem-solving skills, admission at various institutions, pressure from friends, poor academic performance, and uncertainty about sponsor for studies /or lack of financial support, attributed to be some of the major obstacles or barriers that these students are faced with when making a career choice. The data also revealed that there is, seemingly, a greater shift in terms of gender being the influencial factor in choosing a career, implying a greater awareness that more opportunities exist in all facets of the labour market for females, an indication of a slight shift from traditional career choices in the South African labour market. Results are discussed in relation to previous findings, from international and South African literature. The study concludes with recommendations regarding further exploration and examination of the career decision-making of leamers and highlights the implications for career counseling at school and tertiary levels.
\end{abstract}




\section{TABLE OF CONTENTS}

TITLE PAGE

DEDICATION

ACKNOWLEDGEMENTS iii

DECLARATION iv

TABLE OF CONTENTS v v

LIST OF ACRONYMS xi

LIST OF FIGURES AND BOXES xii

LIST OF TABLES xiii

LIST OF APPENDICES $\quad$ xvi

ABSTRACT $\quad$ xvii

CHAPTER ONE: INTRODUCTION 1

$1.1 \quad$ Background and Context 2

1.2 Statement of the Study Problem 10

$\begin{array}{lll}1.3 & \text { The Purpose of the Study } & 10\end{array}$

$\begin{array}{lll}1.4 & \text { Critical Questions } & 10\end{array}$

$\begin{array}{lll}1.5 & \text { The Rationale for the Study } & 10\end{array}$

1.6 Significance of the Study 14

1.7 Outline of Chapters 16 
2.1 Orientation to chapter two

2.2 Clarification of terminology in this study

2.2.1 Career, Job, Occupation, Vocation and Work

2.2.2 Career Choice

2.2.3 Career Development

2.2.4 Career Education

2.2.5 Career Counselling

2.2.6 Career Guidance

2.2.7 Career Life-Planning

2.2.8 Educational and Career Indecision

2.3.1.2 Holland's Theory/ Process of Matching

2.3.1.3 Super's Theory: Person-Occupation Fit 
2.3.3 Occupational Choice as a Decision-Making Task

2.3.4 The Systems Theory Framework (STF)

2.3.4.1 The Individual System

2.3.4.2 The Contextual System

2.3.4.3 The Social System

2.3.4.4 The Environmental-Societal System

2.3.4.7 Recursiveness

CHAPTER THREE: REVIEW OF LITERATURE ON CAREER

3.0 Orientation to chapter three

3.1 Career Education and Guidance Factors

3.1.1 Career Educational Factors in South Africa

3.1.2 Career Guidance Factors in South Africa 
3.2.2 Different Areas (Factors) Addressed by Guidance

3.2.3 Factors Addressed by Counselling

3.2.4 Factors Regarding Sources of Information for Guidance

3.2.5 Factors Pertaining Decision-Making at School

3.3 Closing Comments

CHAPTER FOUR: RESEARCH METHODOLOGY

4.0 Orientation to Chapter Four

4.1 Research Design

4.2 Research Approach

4.3 Pilot Study

4.4 The Sample

4.4.1 Setting and Research Sample

4.4.2 Missing Sample

4.5 Procedure

66

4.6 Instruments

66

4.6.1 Questionnaire 66

4.6.1.1 Components of the Questionnaire 
4.7 Face Validity of Instrument

4.8 Statistical Analysis

4.9 Conclusion

CHAPTER FIVE: DATA PRESENTATION AND ANALYSIS FOR DATA FINDINGS

5.0 Orientation to Chapter Five

5.1 Analysis of Findings

5.2 Quantitative Data Presentation

5.2.1 Description of Sample

5.3 Qualitative Data Presentation

5.3.1 Analysis of open-ended (sections in questionnaire)

6.0 Orientation to Chapter Six

6.1 Summary of Findings

6.2 Discussion of Results 
6.2.4 Influence of guidance by current institution

6.2.5 Summary of the answers to the study's critical questions

6.2.5.1 Social, educational and personal factors

6.2.5.2 Was the guidance programme effective?

6.4 RECOMMENDATION 


\section{LIST OF ACROMYMS}

CAO - Central Applications Office

CRC - Career Resoure Centre

DEC - Department of Education and Culture

DIT - Durban Institute of Technology

KZN $\quad-$ Kwa-Zulu Natal

NCC - National Certificate in Commerce

NGO - Non-Governmental Organisation

PMB - Pietcrmaritzburg

SCDC - Student Counselling and Development Centre

STF - Systems Theory Framework

UWC - University of Westem Cape 


\section{LIST OF FIGURES (AND BOXES)}

Figure 1 The individual System: Intra Personal Influences

Figure 2 The Social System

Figure 3 The Environmental-Societal System

\section{LIST OF BOXES}

Box I A Summary: Lindhard's essential elements of a careers education programme 48

Box 2 Lindhard's programme objectives for teachers

Box 3 Lindhard's definition, influencers and principles of decision-making 


\section{LIST OF TABLES}

Table 1.1 Summary of surveys on UWC's 1st year students career satisfaction

Table 1.2 Summary results of studies of career problems in black high schools between 1970 and 1997

Table 5.1 Profile of respondents according to age

Table 5.2 Respondents age group by gender

Table 5.3 Frequency distribution of all careers listed by total sample

Table 5.4 Profile of sample according to gender

Table 5.5 Profile of sample according to population groups

Table 5.6 Respondents mother tongue by gender

Table 5.7 Profile of sample according to mother tongue

Table 5.8 Respondents' living arrangements

Table 5.9 Influence of who respondents live with on career choices

Table 5.10 Approximate Income Level of family

Table 5.11 Influence of respondents' family incomes on career choices

Table 5.12 Family members responsible for payment for respondents' education

Table 5.13 Influence of who paid for respondents' education on career choices

Table 5.14 Respondents fathers education levels

Table 5.15 Respondents mothers education levels 
Table 5.17 Influence of parent/guardians' educational attainment on career choices 80

Table 5.18 Influence of parent/guardians on respondents' career choices

Table 5.19 Respondents views on who influence their career choices the most

Table 5.20 Sources of most influence on career choices by gendet

Table 5.21 Influence of high school subjects on career choices

Table 5.22 Effect of matric points on the course of study chosen at the technikon

Table 5.23 Availahility of career guidance programme in previous high school

Table 5.24 Availability of career guidance in previous high school of respondents by gender

Table 5.25 Influence of previous high school career guidance programme choices 83

Table 5.26 School's career guidance programme influence by gender

Table 5.27 Rate of performance level of career programmes in the previously disadvantaged high schools

Table 5.28 Respondents' rating of previous high school guidance programme by gender

Table 5.29 Subjects' responses with regard to career counseling received from current institution

Table 5.30 Influence of career counseling of current institution on career choices

Table 5.31 Certainty of respondents about their chosen careers

Table 5.32 Gender influence on career choices 
Table 5.33 Other factors indicated by respondents to have influenced theirr career choices $\quad 86$

Table 5.34 The single most influential factor on respondents' choice of career

Table 5.35 Problems respondents associated with their career choices

Table 5.36 Respondents' rate of the importance of personal information on career choices

Table 5.37 Respondents' rate of the importance of information about careers on their career choices

Table 5.38 Respondents' rate of the importance of information about employers on their career

Table 5.39 Respondents' indication of the importance of information on admission criteria

Table 5.40 Respondents' indication of the importance of information on job opportunities

Table 5.41 Importance of information about financial sustainability on career

Table 5.42 Respondents indication of careers they originally wanted to follow

Table 5.43 Respondents indication on chance factors in their career choice 


\section{LIST OF APPENDICES}

APPENDIX 1 CONSENT FORM

APPENDIX 2 QUESTIONNAIRE

APPENDIX 3 INTERVIEW QUESTIONS

123 


\section{H A P T E R 1}

\section{INTRODUCTION}

The previously disadvantaged sector of the South African population constitutes the majority of its population. When we refer to the term "previously disadvantaged" in the South African context, we often talk of it in relation to the conditions under which the black majority and other non-white races were prejudiced under the apartheid regime. The term was coined when South Africa gave birth to democracy in 1994, under a new dispensation of a non-racial, nonsexist society.

Owing to the diversity of cultures, the process of transformation involves many challenges relating to language, religion, race, and gender issues (Booysen, 1999). These challenges are felt in the workplace as new regulation and policies are implemented to address past imbalances and provide opportunities for previously disadvantaged groups. When the new government assumed power in 1994, new policies and legislations were implemented to address the imbalances created by the apartheid govemment.

However, the assumption that new policy and legislation implementation can balance past imbalances, does not take into account the inadequate social, economic and educational resources of the black majority. The high unemployment rate, unstable and unsafe environment are also not conducive to personal development. This research project will therefore help us to identify some of the main factors militating against youth unemployment and inadequate career choices. The success and effectiveness of career guidance programmes and implementation of government educational policies in schools and tertiary institutions can be measured directly by the amount of success it has in eradicating problems of career choice and unemployment.

As South $A$ frica develops into a new political framework, the challenges of career development become increasingly important (Stead \& Watson, 1998). Attempts towards a formulation of an indigenous approach towards career psychology in post apartheid South Africa as advocated by Stead and Watson (1998), will benefit from a study of career choices and stimulate further research in this area. 
This chapter serves as an entry point into identifying and investigating the factors that influenced the career choices of first year students from previously disadvantaged high schools, at a Technikon in Pietermaritzburg, KwaZulu-Natal: a province in the Republic of South Africa. It is divided into the following sub-section:

\subsection{Background and Context}

1.2 Statement of the Study Problem

1.3 The Purpose of the Study

1.4 Critical Questions

1.5 The Rationale for the Study

1.6 Significance of the study

1.7 Oudine of Chapters

\subsection{Background and Context}

The high level of unemployment in our country is a great cause of concem for the future of all our people. Due to this high level of unemployment, the children of our country are facing the challenges of making the 'right' career choices. The challenges are not only to make responsible career choices in terms of what is available in the job market, but also to widen the career scope for the leamers in the previously disadvantaged schools, particularly the schools in townships and rural settings. These challenges (of making responsible and realistic career choices) can be overcome, if we can lay a good foundation for our children. A good foundation requires that our schools, tertiary, and corporate institutions all take responsibility in education and in defining its purpose and goals. As a society we ought to be asking ourselves serious questions about the quality and purpose of our education. For example, are we producing enough people for the areas that are relevant for the available job market? It would be pointless to continue producing people in the areas in which there is no employment as there are already many qualified people who are without employment in those areas.

It is the researcher's point of view that the family and school directly or indirectly plays a fundamental role in influencing and facilitating the development of the individuals toward 
responsible and realistic career choices which are relevant for the present day South Africa. However, the influence of school and family can have positive or negative results in the career development of the individual depending on how well those in charge play their designated roles. Unfortunately, whether or not the school and family influences have positive or negative results, can only be determined by the direcrion the individuals take after matriculation. At present there seem to be problems in the way that these institutions, in South Africa, contribute to the career development of the children, especially in the previously disadvantaged sector of. our population. According to Singh (1991, p.1), sometimes teachers and parents are guilty of educarional purposelessness in that they disregard the learner's educational needs in a onesided concentration upon the learner's intellectual abilities.

Seven years after the first non-racial school leaving examination in South Africa, the Grade 12 pass rate increased from $47 \%$ in 1997 to $68.9 \%$ for 2002 . Media reports indicated that nationwide, 75048 learners could seek admission to universities in 2003 (Pretorius, 2003, p.16). Whilst some successful, young adults are usually confident about their field of work or study, for the majority, this exciting yet stressful period, after the announcement of the results, is punctuated by questions such as: "What am I going to do? Will I be able to find a job? Will I study? Will I be successful in my career parh? Who will pay for my studies?"

Baijnath (2003, p.2), in her study, highlighted the following points, which are very important and understandably significant contributors toward difficulties in choosing careers for young people:

1. Our school system is not designed to introduce learners to the realities of the world of work

2. Our universities are academic institutions and do not see themselves solely as job factories

3. The human being is capable of operating in a number of different fields successfully

4. No personality preference or aptitude tests are sophisticated enough to produce perfect pointers to specific jobs

5. "Correct" career decisions are dependent on a host of variables such as vocational maturity, accurate information about the field of study, the world of work and selfunderstanding, and, rely on processes rather than one-step operations 
Given the pressures on young people to make early occupational choices, many become anxious about choosing the "right" field of study and career. When one considers the five points listed above, it is understandable, that many successful young Grade 12 learners (matriculants) find it difficult to make quick, seemingly final and accurate career decisions (Gibson, 2000). It is probably worse for those students who come from previously disadvantaged backgrounds in particular, as their situation is influenced by poor environmental conditions as well. Personal and psychological factors are not the only determinants of career choice. Environmental conditions (social, cultural, political or economic) also contribute to career decision-making. It is therefore, very important to establish, comprehensively, all the factors that impact on career choices of students from previously disadvantaged high schools.

According to Baijnath (2003, p.2), the problem of choosing a career and planning intelligently for it, is, probably the most "serious" situation the successful Grade 12 learner is faced with. Baijnath (2003) points out that making a rational career decision is based on three processes as indicated below:

- The first process entails obtaining knowledge about oneself, one's aptitudes, abilities, interests, work values and personality.

- The second process entails obtaining knowledge about the world of work, the prerequisites laid down for the incumbents of the career, the training involved in the careers, as well as the benefits.

- The third process entails an integration of the knowledge about oneself with the knowledge ahout the world of work to choose the career that suits one best.

A wise, realistic choice of career is only possible after careful self-analysis (interests, personalities, and academic strengths) and a thorough knowledge of occupations (Baijnath, 2003, p.2). Planning to take up a career is not only based on careful self-analysis and knowledge of the world of work. Other factors such as parental socio-economic backgrounds and environmental factors with regards to government political policy decisions, technological changes, as well as where one is located and the type of school one attends all play significant roles in ones decision to choose a career and to prepare for it. The preparation programmes in the schools for assisting learners to make career choices and to prepare for these careers are particularly very important. Lindhard (1987, p.179) identified essential elements of a careers education programme which schools need to implement to help learners choose careers and 
to provide them with the skills, attitudes, and knowledge useful for survival and progress in their chosen jobs. According to Lindhard a careers education progtamme teaches a student the following:

- Self-awareness: knowledge about himself, his interests, abilities, aptitudes, etc.

- Educational awareness: knowledge of the education and training available to him

- Career and job awareness: knowledge of the jobs and carcers available, and the entrance requirements

- Decision-making skills: how to make a choicc of career and job

- Employability awareness: knowledge of what is expected in the world of work

Unfortunately, according to Nicholas, Pretorius and Naidoo (cited in Stead \& Watson, 1999, p.1) "De Jong, Ganie, Naidoo, and Prinsloo (1994) pointed out that school guidance and counseling programme in black schools in South Africa, is characterized by marginalisation, discrimination, under-resourcing and underdevelopment". This has been the experience of many students from the previously disadvantaged high school. In many of these schools, the guidance period is either used to cover those arcas that the teachers consider more important curriculum areas for exam purposes, or as free periods where students have to seat quiety and catch up on their homework tasks. As a result the students become very frustrated and anxious when they finish their matriculation, not knowing what the results would be and what they are going to do, however, some may have blur ideas as to what they want to do. For example, some may want to go to university (probably because it seen to be a "status" to study at university) but they are not sure what it is they ivant to study and they are sometimes faced with financial contswaints.

When the results come out, and they have passed, they discover that they cannot gain entry to the university, since they do not meet the entry requirements. They discover this upon attempting to make self-application to the universities where they also can settle for any course on offer - selecting their careers "solely" on the basis of what was offered at that institution (and nothing else. When those students who desperately wanted to study at university fail to secure a place for themselves at universities, they get disappointed and often go on to try at the technikons, where mostly they are fortunate to get a place. The entry requirements and costs at technikons are usually less than those required by universities for most of the courses. 
Sometimes they are discouraged by their parents about the courses or careers that they choose since they (parents) have their own career preferences for them and also because it is them that will pay for the studies. Traditionally, some careers have been perceived to be better than others. For example: to pursue a course leading to a profession like teaching or nursing, was highly regarded because such professions provide stable incomes. The students pursued their tertiary education and in the end obtained degrees and diplomas, for the sake of pleasing their parents than for themselves (students). Some are satisfied in their careers whilst some feel that they were pressured into pursuing those careers. Others will only realize their 'right' career after obtaining their degrees or diplomas - after spending years at the university studying toward a different career. My siblings and I, friends and peers shared similar frustations with regards to career choice difficulties, viewing the situation in our schools (previously disadvantaged) to have been one that had very little or no career education at all.

In the previously disadvantaged schools' environment students are encouraged to apply to tertiary institutions during the marriculation year. Addresses for the tertiary institutions are provided, however, some cannot afford the application fees. Some would even take chances and send the applications - without enclosing the stipulated application fees- in the hope that they may be lucky and get a reply. The other things that appear to contribute to the problems around making career decisions are the cultural practices in our schools that encouraged conformity. As indicated by Bojuwoye (2002, p.287), many students come from authoritarian homes and school systems where they relied on being told what to do. Therefore the demand to seek information independently may be perceived as a threat to one's self esteem as the consequence of asking for help, or making a demand for information, may lead to embarrassment, to one appearing 'stupid' or not to have grown up (Bojuwoye, 2002).

The research findings from various needs surveys administered by the University of the Western Cape (UWC) to all first year students between 1991 and 1994 support the notion that there was deprivation in career guidance on the previously disadvantaged sector of our population (Stead \& Watson, 1998). "As a historically black University, UWC draws the majority of its students from the historically disadvantaged community. As such, this data provides some indication of the extent of career guidance/ counseling deprivation of black population. 
Table 1.1 shows an overview of furst year university student' satisfaction with the guidance received at school level, as well as the number of first-year students experiencing problems with making a career choice:

\section{Table 1.1}

Summary results of surveys on guidance and career satisfaction of first year students of University of Western Cape between 1991 and 1994

\begin{tabular}{|lrrrr|}
\hline Guidance \& Career Satisfaction & 1991 & 1992 & 1993 & 1994 \\
\hline Satisfaction with guidance & & & & \\
$\quad$ Satisfied & 15,4 & 17,3 & 22,2 & 23,4 \\
Dissatisfied & 63,7 & 65,7 & 55,3 & 59,5 \\
& & & & \\
Problems with career choice & 60,7 & 60,5 & 54,9 & 57,9 \\
Yes & 36,4 & 39,2 & 43,8 & 40,0 \\
No &
\end{tabular}

(SOURCE: Stead \& Watson, 1998, p.7)

In all four years the majority of first year-students indicated that they were dissatisfied with the level and extent of guidance received at their previous high schools. The impact of, this inadequate guidance, is demonstrated by the number of first year students who are experiencing problems with making a career choice. 'The majority of respondents indicated that they were experiencing major problems in this regard. The data in a table below (Table 1.2) provides some indication of the perceived career guidance needs of black students, a need that is further substantiated by the various needs assessments undertaken among black students. A summary of some of these needs assessments is presented as follows:

Table 1.2 Sumnary results of studies of career problems in black high schools between 1970 and 1997.

\begin{tabular}{|c|c|c|}
\hline Year & Author & Findings \\
\hline 1970 & Herman & $\begin{array}{l}94 \% \text { of matriculants in the study experienced } \\
\text { problems with career choice. }\end{array}$ \\
\hline 1983 & Chuenyane & $\begin{array}{l}90 \text { of high school pupils had serious career } \\
\text { planning problems }\end{array}$ \\
\hline 1988 & $\begin{array}{l}\text { Van Schoor } \\
\text { \& Whittaker }\end{array}$ & $\begin{array}{l}\text { the majority of students in the survey } \\
\text { experienced problems of a vocational nature }\end{array}$ \\
\hline 1995 & Nicholas & $\begin{array}{l}\text { the need for assistance with career concerns } \\
\text { is much higher in black South African sample } \\
\text { than for North American sample. }\end{array}$ \\
\hline 1997 & Nicholas & $\begin{array}{l}\text { the highest need for help or information was on } \\
\text { job search strategies. }\end{array}$ \\
\hline
\end{tabular}


Despite these consistent indications of where the greatest need exists, in terms of carcer guidance, a review of research on career counseling shows some surprising trends:

1. In general, published research was found to be lacking. In their review of research conducted in South Africa between 1980 and 1990, De Bruin and Nel (1996) could find only 22 published articles (i.e. $14 \%$ of all resources reviewed). As indicated by Nicholas (1997), this lack of published research impoverished the knowledge base that informs the changing counseling practices.

2. There is a noriceable bias in favour of white samples as more than $50 \%$ of the research undertaken focused on white samples.

3. In their review of career rescarch in South Africa from 1980 to 1997 , Stcad and Watson (1998) point out the following, that:

- Prior to 1990), career theories developed in the United States of America were accepted without question by South African Researchers. Since 1990, however, researchers have started to question the appropriateness of these theories.

- Research on career education has largely been conducted at tertiary institutions despite indications that it may be even more important at primary and secondary school levels.

- Although some work has been done on examining the psychometric properties of intemational career instruments, very little original instrumentation has been developed in South Africa.

Many researchers have responded to the call for relevancy by increasing the diversity of their samples. Stead and Watson, however, cautioned that the inclusion of more black samples in research does not in itself deal with the issue of culture" (Stead \& Watson, 1998, p.7-9).

Kekana (2003, p.2) concludes that lack of career guidance and counseling for the black youth in South $A$ frica has resulted in a number of problems that include:

- poor academic performance; 
- wrong career choices;

- high failure and drop-out rates; and,

- moving from one course to the other at tertiary institutions

Students who seek counselling at Career Counselling and Development Centres in educational and other institutions are at different levels of vocational indecision and educational indecision. Several studies done in South Africa (Smith, 1993; Van Vuuren, 1991; Watson \& Allan, 1989; Stead \& Watson, 1990) have examined the career development of high school pupils, taking into account role salience, career decision-making skills and career development across cultures. To date none of the South African studics has empirically investigated the relationship between vocational indecision and educational indecision.

The present study will therefore examine this problem, focusing specifically on the experiences of students at DIT (Durban Institute of Technology). Many of these students come to the institution with no idea of why they want to enter a particular educational programme, or occupation, or why they want to change from one educational programme to another (Beerlall, 1997). Unwise carcer decisions and pursuance of wrong or inappropriate educational courses can have far-reaching negative implications for both the education and career satisfaction of the young adolescents. To make a responsible career choice, the secondary school leamer needs a career choice identity, based on self-knowledge and career knowledge (Stead \& Watson, 1998, p.291). Without adequate 'stimulating environment', nurturance, resource availability, support, and service provision at primary level, any other form of intervention will be to normalize an otherwise crisis situation. Pryor (1985) pointed out that learners who have experienced the following situations pose particular challenges for career educators:

- Limited exposure to the world of work

- Little access to career education services

- No knowledge of large tertiary institutions

- A narrow range of social contacts

Consideration of these four categories of learners in the light of the context described above has brought realization that large numbers of South African youth and adults would fit into one or more of these categories, thus emphasizing the extent of the need for career education in this country. 
The problem of this study can be put in form of a question: "What are the factors that contribute to career choice difficulties of first year technikon students from previously disadvantaged high schools?"

\subsection{The Purpose of the Study}

It is the general purpose of this study to identify the factors impacting on career choices of first year technikon (DIT) students from previously disadvantaged high schools. Specifically the study is designed to find out social, educationah, and personal factors impacting on career choices. The study is also designed, or aimed, at finding out whether in the opinions of the respondents of this study, the high schools they attended had guidance programmes which were effective enough to assist in their career choices. The study will also look at the current institution (DIT) of the respondents with a view to finding out if the institution played any role in aiding their career choices. Critical questions two and thrce tend to introduce two different areas of research and could be studied in their own right, however, they have been included to explore the guidance and counselling areas in relation to the present study. The following critical questions, therefore, serve to focus the study:

\subsection{Critical Questions}

The critical questions that guide this study are:

- What are the social, educational and personal factors that influence the career choices of technikon students from previously disadvantaged high schools?

- Do the respondents consider they had effective guidance programme in their previous high schools?

- What role does the student counselling and development center in their current institutions play, in aiding the first year students from previously disadvantaged high schools, with regard to career choice difficulties.

\subsection{The Rationale for the Study}

Career development and its associated problems have been studied for some time now in the United Kingdom and in the United States. Countries such as South Africa have relied quite 
hcavily on the research findings based on those particular counwies. Research in South Africa, however, is beginning to examine issues related to career development, but more still has to be done regarding factors impacting on career choices of students from previously disadvantaged high schools. The tremendous change since 1994 in South A frica, which heralded a new order, with a democratically elected government has been particularly dramatic for South African career education. With democratic and human rights values sipping down from the nation's governance to educational institutions has resulted in the increased opportunities for higher education and in the workplace. This has also resulted in more students from previously disadvantaged high schools studying for, and working in jobs previously closed to them. Intervention at a political leveh, by a govemment committed to a policy of equality and affirmative action, has opened up opportunities rapidly and ensuring that education institutions reflect the appropriate demographic composition of the country.

There is paucity of research, documenting factors impacting on carcer choices of students from previously disadvantaged high schools. There is also very little evidence which indicates that these schools have effective cateer education programmes. As a result, there is no indication as to what extent change has filtered down, and how it has affected perceptions of cateer opportunities and choices. There is need for research in the area of career development and education, so that we can better understand the trends in our own country, and then be in a better position to intervene where necessary and make effective recommendations.

In South Africa career education and development is a sector where the ravages of apartheid temain most evident. In the National Educational Policy Act of 1967, legislation of a National Guidance Service for whites was viewed as an auxiliary service and was characteristically didacric, overtly moralistic and aimed at guarding the identity of whites. The National Education Policy Investigation (1992) found that guidance and counseling services in South Africa had been neglected and did not exist for the majority of the pcople. According to De Jong, Ganie, Naidoo and Prinsloo (1994), school guidance and educational programmes in black schools are described as being characterized by marginalisation, discrimination, underresourcing, and underdevelopment (Stead \& Watson 1991, p.1). This was further supported by the various needs survey findings, such as those administered by the University of the Western Cape to all first year students between 1991 and 1994. As indicated in the background earlier, 
this data provides some indication of the extent of carcer guidance deprivation on the previously disadvantaged sector of our population.

This study will help contribute toward better understanding of career development trends in the previously disadvantaged sector of our councry's population in the post apartheid cra. It will also serve as an evaluation on how far the legislations and policies have gone in transforming the condirions of the previously disadvantaged schools as far as career guidance programmes are concerned. It will provide us with evidence of what the most significant factors are that are impacting on career choices of students from previously disadvantaged high schools. We will also be able to evaluate whether any progress has been made, in the career development area, ten years after the democratic government took over.

When the new government assumed power in 1994, new policies and legislations were implemented to address the imbalances created by the apartheid government. The assumption that new policy and legislation implementation can balance past imbalances, does not take into account the inadequate social, economic and educational resources of the black majority. The high unemployment rate, unstable and unsafe environment are also not conducive to personal development. This research project will also help us to identify some of the main factors militating against youth unemployment and inadequate career choices. The success and effectiveness of carcer guidance programmes and implementation of government educational policies in schools and tertiary institurions can be measured directly by the amount of success it has in eradicating problems of career choice and unemployment. These programmes, according to Lindhard (1987, p.179), should provide students with the knowledge, skills, atritudes, and values useful for survival and progress in their chosen jobs. These programmes should teach students self-awareness, educational awareness, career and job awareness, decision-making skills, and employability awareness. If, after ten years of a democratic govemment in South Africa, the problems of career choice still shows similar trends as before ten years ago, it would only mean no progress has been made in the area.

This would probably also explain why many black students in South Africa experience problems such as making wrong career choices, the high failure rate, dropout rates, and moving from one course to another in tertiary institutions. It would probably also explain why we have such a high rate of unemployed graduates. That situation could mean a very 
important aspect of the student development is being ignored, and that an urgent attention needs to be given to this area by the schools as well as the policy makers in the ministry of education. As Singh (1991, p.1) clearly points out, that sometimes teachers and parents are guilty of educational purposelessness in that they disregard the learner's needs in a onc-sided concentration upon the learner's intellectual abilities.

The schools should provide structured guidance and counseling and curriculumn programmes that are effective. They should begin at primary level and be continued up to the tertiary level. Guidance seen as a continuous process starting from the date of entry by pupils to secondary education appears to offer the following advantages, as highlighted by Vaughan (1970, p.58):

- The development of the individual can be observed, and perhaps related to some theory

- When educational and vocational guidance are seen as part of the same process, there is more hope that the subjects studied in secondary school will have some bearing on the work taken up after the pupil leaves

- Although objective psychometric tests only give a static picture of the individual at a moment in time, a programme of continuous guidance makes it possible to use batteries of tests at different times, so allowing staff to trace the pattem of change

- The child may develop a more responsible attitude to his own furure where this is made an important study in its own right throughout school

- In a lengthy guidance scheme, a greater overall amount of carecr information can be passed on to the pupil.

- Many important aspects of guidance can be covered before the earliest pupils begin to leave.

Teachers and learners should mutually accept the responsibility for the learning and education situation in which they find themselves. In order to help leamers to accept such responsibility, teachers ought to break down the existing barriers to leaming. There is an outcry in South Africa over the quality of education offered in black schools. Educators and parents are 
concerned about the quality of education in these schools in comparisen with that of historically white schools. Given the high cost of post matriculation studies in South Africa, it is imperative that students choose careers that are consistent with their interests and apritudes. In this way students are more likely to succeed academically and to experience course and job satisfaction.

This study will therefore provide impertant baseline data. Baseline data is necessary to provide a framework and a context for discussion, policy planning, implementation and evaluation. This study will further provide valuable information for future research. This information is necessary for policy planning and evaluation, but is also impertant for effective carcer counselling and guidance programmes at primary, secondary and tectiary levels.

\subsection{Significance of the Study}

Career research has focused more on persønal and psycholøgical factors as determinants $\bullet$ carcer choice. Few studies investigated environmental conditions (social, cultural, pelitical or economic) as determinants of career decision-making. It is important to establish, comprehensively, the factors that impact on career choices of students from previously disadvantaged high schøols. This study therefore aims at providing useful information indicating what factors significantly influence learners from previously disadvantaged schools in their career choices.

The results of this study will have important implications for students who are still at scheol and yet to make career choices, as well as implications for parents, educators, the community, education departments, career counsellors at schools, student counselling centers at tertiary institutions, empløyment market sector, and researchers.

The results of this study will als $\bullet$ provide information that will create awareness to high school learners and educators in the previously disadvantaged institutions. With information they will be empowered, and hopefully, begin to critically evaluate their own situations regarding their career development initiatives. A clear and realistic understanding of one's learning is instrumental in empowering the individual in many areas of his or her life, including secial, familial, academic and vocational situations. W'ithout an understanding and acceptance of one's abilities, individuals are not able to select appropriate geals and advocate for themselves. In 
addirion, ignorance by teachers and students towards their own career development can lead to making wrong career choices. The maturation of a high school student's vocational preferences is in part related to the maturation of one's abilities and interests. Each shift in vocational preference is a step in the process of testing reality. The student's later choices are a compromise between his individual traits and social factors, as well as between his conception of himself and reality. This process goes on with or without counsel. With adequate counseling, however, the final compromise tends to be more realistic and stable (McKinney, 1958, p.358).

This study will benefit higher institutions (students, prospective students and the Student Counseling and Development Centres), previously disadvantaged high schools, and the community at large. The findings can be used for a realization of liaison between the technikons and schools (outreach programmes), facilitation and development of career programmes to be compulsory in the school and technikon curricular, recommendations for all first entry students to have career counseling (compulsory) before enrolling for the academic year, recommendations that technikons re-examine their admission criteria or review their admission policies, recommendations that the technikon provide the finances for an effective orientation programme for all first-entry students (considering having an open day for parents of prospective students so that technikon management give parents the opportunity of getting first hand career information for their children as well as establishing a friendly relationship with the institution. In that way students, parents and the community will develop a better image of the techrikon. It is also very important for the Kwazulu-Natal, Department of Education and Culture (KZN, DEC) to improve linkages between secondary and post secondary education institutions.

It is further expected that the proposed research will provide crucial data indicaring the perceived career guidance needs for black students, and thus further substantiate the various needs assessments and research studies undertaken among black students. The research project will extend and integrate theory and findings from several areas of research relating to career guidance and education. Career development theories will be explored in the context of South Africa. Career choice theoretical models will be explored with a view to expanding the notion that; without adequate 'stimulating environment', nurrurance, resource availability, support, 
and service provision at primary level; any other form of intervention will be to normalize an otherwise crisis situation. In a study conducted by Kekana (2003, p.2), he pointed out that lack of career guidance and counseling for black youth in South Africa has resulted in a number of problems, which include: making wrong career choices, high failure and drop-out rates, and moving from one course to the other at tertiary institutions. It is hoped that findings from this study will contribute toward dealing with such problems.

The study will also help in the Policy Decision Making, to help education policy makers take a stronger view on the position played by previously disadvantaged schools on carcer development of leamers. It will also help empower both the parents and students who are still faced with the challenges of career decision-making.

\subsection{Outline of Chapters}

The chapters in this study will be as follows:

\section{Chapter One:}

An introductory chapter which contains motivation for the study with relevant background information as well as its purpose and importance.

\section{Chapter Two.}

It provides the literature review undertaken with the specific reference to career development theories.

\section{Chapter Three.}

It provides the literature Review and looks at the historical background and the development of career education and guidance programmes in South Africa and elsewhere. This is done in line with needs of this study.

\section{Chapter Four.}

This chapter explores the research methodology utilized for this study: The chapter focuses on research techniques and data collection instruments and the procedures and methods used for the collection of data, design and sampling in this study.

\section{Chapter Five.}

This chapter presents the results of this study, as well as data analysis.

\section{Chapter Six:}

This chapter presents the summary of findings of the study and the discussion of the findings and conclusion. The chapter also provides recommendations and prospects for further research. 


\section{H A P T E R 2}

\section{THEORETICAL FRAMEWORK}

\subsection{ORIENTATION TO CHAPTER TWO}

This chapter has two aims, firstly, to clarify the terminology used in the study, and secondly, it undertakes to discuss the theories underlying career choice to enable the readers to understand and appreciate the different factors influencing the career decision-making of people. A discussion of relevant theories, in section two below, will provide a lens towards understanding the career choices of individuals and towards providing the answers to the purpose and the critical questions in this study. The purpose of this study is to identify the factors impacting on career choices of first year technikon students from previously disadvantaged high schools. The critical questions are:

- What are the social, educational and persenal factors that influence the career choices of technikon students from previously disadvantaged high schools?

- Do the respondents consider they had effective guidance programmes in their previous high schools?

- W'hat role does the student counseling and development center in their current institutions play, in aiding the first year students, with regard to career choice difficulties.

\section{SECTION 1: Clarification of 'Terminology}

SECTION 2: Theories of Carecr Choice relevant to this study

SECTION 3: Closing Comments for the Chapter

\subsection{SECTION 1: CLARIFICATION OF TERMINOLOGY IN THIS STUDY}

\subsubsection{Career, Job, Occupation, Vocation and Work}

The terms career, vocation, work and occupation are often used interchangeably in the literature. However, the terms do not mean exactly the same thing. The discussions ahout 
these terms below are meant to clarify their true meanings and their uses in the context of this research.

From the time of Parsons (1909), the terms iareer, wiation, work and octupation have been used synonymously (Mcdaniels \& Gysbers, 1992). Traditional definitions restricted career to a professional work life that included advancement and several researchers have proposed broadening this conceptual definition. For example in the definition proposed by Super (1976, p.20), career implied: "The sequence of major positions occupied by a person throughout his or her pre-occupational, occupational and post-occupational life; includes work related roles such as those of student, employee and pensioner together with complimentary vocational, familial and civil roles."

Tiedman (in Gordon, 1981, p.435) defines career as "the imposition of direction into the vocational behaviour of a person which is subject to his comprehension and will".

Collin and Watts (1996, p.393), proposed a more flexible approach to defining career. They defined career as "a lifelong process in which patterns and relationships between work and other areas in life are constructed within the leamer in an ongoing way."

A more concise definition, that of Arthur, Hall and Lawrence $(1989$, p.9), described career as "the evolving sequence of a persons work experience over time," emphasizing the centrality of the themes of work and ime. 'They were emphatic that, "every one who works bas a career," indicating that the term career can be a neutral descriptive term applied to all occupations.

According to Zunker (1998, p.7), the terms vacation, occupation and job, are used interchangeably to indicate activities and positions of employment. Caner refers to the activities and positions involved in vocations, occupations, and jobs as well as to related activities associated with an individual's lifetime of work (Zunker, 1998, p.7).

As far as Figler and Bolles $(1999$, p.11 - 12) are concem, "the word job refers to a particular place where a person is employed. The word occupation refers to a job title, such as enginect. Thus an engineer may, over a number of years, hold down four different jobs, at four different engineering firms. Of course, people change jobs, but it is common also to change occupations. This is most commonly described, however, not as occupation change but as a career 
change. The word career is used in the world out there in several senses - all related to the general subject of occupations or jobs in the world of work:

The following are some of the senses in which the word career refers to:

1. It is used, first of all, in contrast to leaming or leisure. "Thus when clothing ads speak of "a career outfit" they are referring to clothes which are worn primarily at work, rather that during leaming activities or leisure activities.

2. It is used, secondly, to sum up person's whole life in the world of work Thus when people say of semeone at the end of their life, "He (or she) had a brilliant career," they are not referring to a particular occupation, but to all the occupations this person ever held.

3. Thirdly, in its most common sense, it is used as a synonym for the word occupation or job - particularly where that occupation or job offers opportunity for promotion and advancement, toward the top.

Richardson (1993, 1996) suggested that career is a limited and irrelevant concept. She proposed that theoreticians and practitioners focus on low people create their own definitions of work in their lives and suggested the use of the terms: work, jobs, occupations and carters in the discussion of work and career. According to Brown and Brooks (1996, p.213), "this lack of conceptual clarity maintains ambiguity and continues to prevent the development of a common ground of thinking in this area." As the terms career, vocation, wort and ocuspation are variously understood, they will be used interchangeably in this study.

Super's definition of career is all - encompassing and acceptable to the researcher. However, for the purpose of this study the definitions given by Crites and the one given by Collin and Watts will be more appropriate as the focus in this research is on factors impacting on career choices of technikon students.

\subsubsection{Career Choice}

According to Bolles and Figler (1999, p. 12) "occupation or career choice is typically first made when a person finishes high school. One can choose today from among at least 12,741 
different occupations/careers/job-tittles, which have some 8,000 alternative job-tittles, for a total of over $20,000 . "$

Career choice involves processing developmental tasks and resolving psychosocial crisis. All theories, systems, and strategies underscore the inclusive and complex nature of the career choice process. Because individuals experience periods of indecision and indiscriminateness, career choice is not considered wholly conninuous (Super, 1990). Career choices are tentative from the standpoint that practically every choice involves some doubt about the credibility of the chosen career and the possibility that it can be successfully carricd out over a lifetime. The individual's uncertainty is compounded by the carcer possibilities that have disappeared because of changing economic conditions and the career uncertainties and unknowns forecast by vast imminent technological changes. Moreover, career choice is a process in which one not only chooses but also eliminates and consequently stifles some interests and talents. Parts of us are left to go to seed when a career choice is made, because eventually we must give up a chance to develop talents and interests as we limit ourselves on a narrow pathway leading to a career. Career choice is also clouded by the search all of us experience for self-identity and meaning in a world society that is drawing closer together. (Zunker, 1998, p.92-93)

\subsubsection{Carecr Development}

According to Zunker (1998, p.7), Career development as defined by the American Counselling association "is the total constellation of psychological, sociological, educational, physical, economic, and chance factors that combine to influence the nature and significance of work in the total life span of any given individual" (Engels, 1994, p.2). He went further to add that "specifically, the term reflects individually developed needs and goals associated with stages of life and with tasks that affect career choices and subsequent fulfillment of purpose"( Zunker, 1998, p.7).

\subsubsection{Career Education}

Career education according to Zunker (1998), is a concept that emerged in the early 1970s in reaction to the charge that the current education systems were not adequately preparing the youth for work, in the United States. "This new educational philosophy - career education - 
was considered integral to the educational process, from kindergarten through adulthood. The career education programmes that evolved during the 1970s have centered on such topics as career awareness, career exploration, value clarification, decision-making skills, carcer orientation and career preparation. Understandably, careet education programmes have focused more attention on the carecr guidance movement." (Zunker, 1998, p.17)

\subsubsection{Career Counselling}

"Career counselling includes all counseling activities associated with career choices over a life span. In the career counseling process, all aspects of individual needs (including family, work, and leisure) are recognized as integral parts of career decision-making and planning" (Zunker, 1998, p.7).

\subsubsection{Career Guidance}

"Career guidance encompasses all components of services and activities in educational institutions, agencies, and other organizations that offer counseling and career related educational programmes" (Zunker, 1998, p.7).

\subsubsection{Career Life-Planning (Zunker, 1998, p. 91-94 \&106 - 7)}

Several career-counseling programs are designed to promote career life planning as a lifelong process. Each program considers career life planning as a developmental process that must encompass needs generated from work, family, home, and leisure. Each program focuses on strategies that assist individuals in meeting these needs and adjusting to changes that are both internally and externally caused. Some of these carecr life-planning programs are useful for this study because they link with comprehensive school guidance programs. Such useful programs present career life planning as a promotion of personal competence, introducing skills that are helpful in meeting future events. Some programs introduce methods of identifying dimensions of lifestyle associated with work, family, home, and leisure. More specifically, this program focuses on such factors as place of residence, marital status, levels of education and income, family status, leadership needs, social opportunicies, and major goals in life. Lifestyle dimensions are compared with potential career choices in an attempt to determine lifestyle 
congruence with certain careers. Clarification of lifestyle dimensions can be accomplished through group or individual counseling.

In the process of carrer life planning, the individual uses a variety of skills. One of the primary purposes of career life planning is to develop skills through which individuals learn to control their futures. For example, we learn to identify our skills and plan how we can continue to upgrade them through life-leaming programs. We leam how to develop options and alternatives and effectively decide which to follow. We learn to identify our personal needs and the needs of our closest associates and how to integrate those needs into our life plans. W'e learn to make plans that we can change and revise as we ourselves change or as circumstances necessitate change. Thus, our planning must be flexible and include realistic options from which effective decisions can be made to promote a fuller and more satisfying life. As we pass through various stages of life and as situational changes occur, we set goals, choose from options and alternatives and make decisions. For many, the process of change is difficult and threatening, particularly for those who haphazardly chart their course only to find frustration and dissatisfaction. Through career life - planning, we learn to center our attention on carefully laid plans and on those variables over which we have some control. There are many variables to be considered in career life-planning programs. One is how we judge success. This is a crucial decision consciously or subconsciously faced by everyone. For a career counselor, for example, the concerns are centered on the success criteria with which they evaluate their lives and others evaluate them. These success criteria are based, to a great extent, on the kind or quality of work we do. What motivates us to work is a key question. According to McClelland (1961), people have a driving need for achievement and subsequent power over others. Other work motivators are the security and symbols of success that come from earning money, identification with prestigious organizations or peer affiliates, and status associated with certain occupations and professions (O'Toole, 1981). Central to our concems, however, are the intrinsic satisfactions from which individuals judge their success in life and work. We should recognize that these judgments may change as individuals' needs change over their life spans. We should set a goal of providing flexible career life planning that can help individuals identify their changing needs and set realistic goals to meet them. 
Super (1990), among others, has suggested an integrative approach to carcer counseling that focuses on the development of life roles over the life span with emphasis on inter-role congruence. Hansen's (1996) integrative life planning model incorporates career development, life transitions, gender role socialization, and social change. These integrative approaches recognize a broad spectrum of domains that must be considered in career life planning. The comprehensive career life plan considers all career life roles including relationships, as major comprehensive view of development. Through career life-planning programs, we not only provide sources of education and training, but we assist individuals in determining their needs for programs and in understanding the reasons for a life-leaming concept. As we project into the future, our major effort should be to identify those variables in our lives over which we can exert some control. Our lives can be charted more effectively through the maze of changes that we experience, both individually and situationally, by planning programs that place these variables in perspective

Career life planning focuses on a significant number of factors that influence career choice. Setting priorities and goals for career life planning, developing ultimate life designs, and setting long-range and short-term goals are major choice objectives. In career life planning, values, interests, abilities, achievement, and work-life experiences are viable factors to discuss, evaluate, and clarify when making career life-planning determinations. Decision-making models also provide a framework from which career-choice counseling objectives are derived (Gelatt, 1989). Clearly defined steps in decision-making strategies provide sequences designed to assist individuals in making a career choice.

One problem-solving approach for career choice was suggested by, Tiedeman and O'Hara (Tiedeman \& O’Hara, 1963). Career choice involves processing developmental tasks and resolving psychosocial crisis. All theories, systems, and strategies underscore the inclusive and complex nature of the career choice process. Because individuals experience periods of indecision and indiscriminateness, career choice is not considered wholly continuous (Super, 1990). Super (1990) also considered indecisiveness as a period in the developmental process when interests have not been fully crystallized. Uncertainty about future career goals may lead some individuals to make indiscriminate choices of twe or more occupational objectives. As individuals become more aware of the developing character of the career process itself, they 
are more willing to make changes or to alter or redefine a decision (Miller-Tiedeman \& Tiedeman, 1990; Healy, 1982). The process of deciding is complex and unique for each individual, depending on cognitive factors and the social structure of the individual's milieu. In essence, individuals evaluate their choices internally by considering their values, interests, achievement, and experiences and externally by seeking acceptance and approval within the working environment.

In career life-planning programs, career choices are tentative from the standpoint that practically every choice involves some doubt about the credibility of the chosen career and the possibility that it can be successfully carried out over a lifetime. The individual's uncertainty is compounded by the career possibilities that have disappeared because of changing economic conditions and the career uncertainties and unknowns forecast by vast imminent technological changes. Moreover, career choice is a process in which one not only chooses but also eliminates and consequently stifles some interests and talents. Parts of us are left to go to seed when a career choice is made, because eventually we must give up a chance to develop talents and interests as we limit ourselves on a narrow pathway leading to a career. Career choice is also clouded by the search all of us experience for self-identity and meaning in a world society that is drawing closer together. Fortunately, career life-planning progtams provide for a regular reevaluation of where we have been and where we are going. Opportunities are available to reconsider choices of the past and to realign them with new values, interests, and changing workplaces. Those talents and interests that have remained latent can be nurtured and developed in career life-planning programs.

\subsubsection{Educational and Career Indecision}

Because of the lack of adequate resources in the previously disadvantaged high schools, many leamers are uncertain about their future. The factors that militate their uncertainty or undecidedness range from financial support to factors such as lack of knowledge about carecrs and training requirements amongst others. Many words associated with the verb "decide" have been used interchangeably in the literature and insufficient attention has been given to adjectives such as "decided", "undecided", "decisive" and "indecisive". The tesult is linguistic havoc in the literature pertaining to students who have or have not made a decision about their career or major (Salomone, 1982). Salomone (1982, p.498) maintains that "undecided and 
indecisive" are adjectives that should be used to describe different types of people. It is possible for an individual to be both decided and decisive, as it is possible to be undecided but of a decisive nature. It is believed that vocational decision-indecision comprises two subconcepts with attendant behaviours. I his is contended in the following continua:

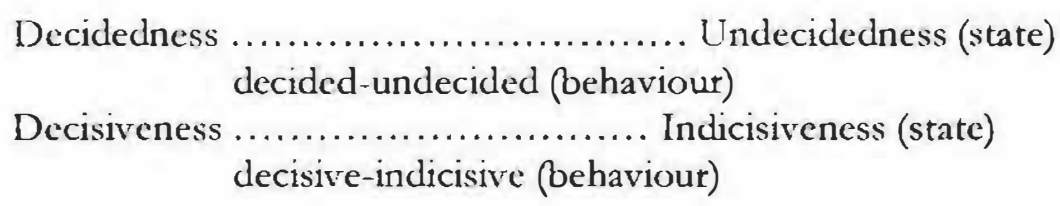

In the first continuum the counselor has to explore a rational-cognitive issue with a development aspect. The second continuum in contrast to the first, foregrounds an emotionalpsychological issue, with a development aspect. An indecisive person can be described as one who would fail to make important decisions not because he/she lacks sufficient information but because his/her personal qualities do not allow him/her to teach a "decisional state of mind and take a course of action" (Salomone, 1982, p.497). Indecisive people are not capable of making critical decisions because psychologically they are incapable of such behaviours. This can therefore be one factor, in which learners who have not been psychologically prepared (such as those from the previously disadvantaged high schools) duc to inadequate facilities or lack of career guidance, that can impact on the career choices of learners.

Some authors have referred to indecision as a chronic condition (Fuqua \& Hartman, 1983a; Fuqua \& Hartman, 1983b) and relate career indecision to serious psychological problems such as situational anxiety, characteristic anxiety and self-perceptual problems. Tyler (in Salomone, 1982, p.497) described the indecisive student as "fraught with personal problems that are demonstrated by neurotic and maladjustive behaviour". She refers to individuals who seem to have difficulty in making all sorts of life decisions. Crites (1969, p.303) defines vocational indecision as "the inability of the individual to select, or commit himself to, a particular course of action, which will eventuate in his preparing for and entering a specific occupation". Another distinction is made between indecision and indecisiveness. According to Van Vuuren (1991, p.23), "indecision is applicable only to career choice, whereas indecisiveness is a more general term related to an underlying personality wait where the ability to take decisions and the responsibility for decision-taking behaviour, is part of the individual's interaction style". 
In the present study that explores the factors impacting on carcer choices of first year technikon students from previously disadvantaged high schools, in the light of the discussion above, career indecision and educational indecision, is viewed as a rational-cognitive issue. The term indecision is used as it applies only to career choice. This is so because of the lack of adequate outlets that could be facilitating decision-making and the general career development of leamers. This indecision can be attributed to as a factor impacting on career decision or choice of the learners. Other studies (Gordon, Bergeron \& Romano, 1994) indicate that there are significant numbers of vocationally undecided and educationally undecided students where educationally undecided refers to those students who have not decided on a major or academic course. Those students have not decided due to a number of factors and according to Beerlall (1997) some of the main militating factors are parents' education, matric points, interests and hobbies, and, lack of information about the courses.

In a study by Beerlal (1997, p.137), where she investigated career decision-making: the relarionship between vocational indecision and educational indecision, her findings indicated that there is a significant relationship between vocational indecision and educational indecision. She reported that: "students who reported being decided on their majors reported the same level of decision about their vocation. However, students also reported being decided on their majors as being undecided on their vocation. The reverse was also true for students who were decided about their vocation, but were undecided about their majors. These differences were found in relation to the variables of gender, population, and language groups. There were significant differences relating to gender and culture conceming educational and vocational indecision. 'Therefore, indecision and, or, undecidedness is a major factor on its own, and can precipitated by various other factors in the lives and environment of the leamers from previously disadvantaged high schools.

Ieerlal (1997, p.137) also added that she hoped conclusions of her study about the influence of major factors on the complex process of career decision-making both educationally and rocationally were enlightening. According to Beerlal (1997, p.121) "factors such as parent's education levels, matric points, finance, admission criteria, interests and hobbies, research into the occupation, school subjects and experience at school, information about job opportunities, 
information about yourself and information about careers were identified as important influencers in the career decision making process.

\subsection{SECTION 2: THEORIES OF OCCUPATIONAL (CAREER) CHOICE}

This section undertakes to discuss the theories underlying eareer choice in order to establish an understanding and appreciation of the different factors influencing the career decision-making of people.

The structural theories match personality and abilities with occupation and environment. The development theories explain career development in chronological stages. Other theories, such as the expectancy theory, assume that people develop expectancies regarding the likelihood that they could successfully enter an occupation, if they put forth sufficient effort. As no single theory is comprehensive enough to account for the complexities of human behaviour, the Systems 'Theory Framework (STF) will be used as a vehicle to conceptualise the occupational choices of students from previously disadvantaged high schools for the following reasons:

- The Systems Theory is "eclectic" in nature

- It is broadly based and is able to take into account the diversity and complexity of the influences on career development.

\subsubsection{Occupational Choice as a Matching Process:}

\subsubsection{Trait and Factor Theory}

Most theories of occupational choice contend that a person, consciously or unconsciously, chooses an occupation that "matches" his/her unique set of needs, motives, values and talents. One of the earliest approaches to occupational choice, so-called rait and factor theory, is perhaps most explicit in this regard. According to this viewpoint, "confronted with the necessity of ihoosing an occupation, an individual conscionsly proceeds to make an analysis of his/ her vocational assets and liabilities, aciumulated information about occupations, and amires at a decision" (Crites, 1969, p.17). Consistent with this view, a person would be expected to identify his/her abilities, needs, values, select appropriate career goals, and then choose an occupation thought to be most compatible with these goals. The theory assumed that choice was available for everyone. 
Career choice was viewed as a single, static, point-in-time event, for which there was single right answer.

The assumption invites criticism. For example, it has been questioned whether people actually use reasoning in all career choices and whether all people actually have a reasoned choice in relation to career. It can also be questioned whether occupational choice is a single event, whether single types of people are found in each type of job, or whether there is a single right goal for each career decision maker. Issacson and Brow (in Baijnath, 2003) claimed that the trait-and-factor theory does not account for the broad range of individual differences in every occupational group. In addition it has been acknowledged that people make several career choices in a liferime (Patton \& McMahon, 1999; Greenhouse, 1996).

Criticism has also been leveled at trait-and-factor theory for failing to "adequately consider and define the universe of variables that impinge on the occupational choice making process and define causal relations among traits and variables (such as socio-economic status)," (Brown, 1990, p.346). Zunker (1994) was critical of the failure to account for growth and change in traits such as interests, values, aptitudes, achievements, and personality chatacteristics. Brown (1996b, p.347), claimed that, "in its current state, trait-and-factor theory cannot stand alone as an explanatory system for occupational choice making and has even less validity as an explanatory system for the career development process". Thus it would be fair to say that wait and factor theory is not a theory of career development but rather a collection of theories based on influences that contribute to career development.

\subsubsection{Holland's Theory/Process of Matching}

The work of Holland $(1966,1985 a, 1987$ a) also views occuparional choice as a process of matching occupations and people. One of Holland's major assumptions is that "people searith for environments that will let them exerise their skills and abilities, express their attitudes and values, and take on agreable problems and roles" (Spokane, 1996, p.38). His theory has been described as "primarily descriptive" and has been criticised for not adequately addressing the needs of women and of racial, ethnic and other groupings. Holland proposed six personality types as they relate to occupational interests, preferences and inter-relationships. According to Holland, for an individual to experience success, sarisfaction, and stability, it is essential that there is a match between the work chosen and his or her personality. 


\subsubsection{Super's Theory: Person-Occupation Fit}

Super's extensive work $(1957,1963,1990)$ is also based on the notion of match between individuals and occupations. The key concept in his model is the person's self-concept. Our self-concept, in other words, consists of attributes we think we possess: our abilities, personality traits, needs, interests and values. Super believes that an occupational choice enables a person to play a role appropriate to the self-concept. A person "implements" his/her self-concept in developing an occupational choice; that is, he/she selects an occupation that is compatible with significant parts of the self-concept. In effect, people develop a self-concept, develop images or beliefs about a series of occupations, and take steps to enter the occupation that is most compatible with their self-concept (Greenhaus, 1996).

\subsubsection{Occupational Choice as a Developmental Process}

Self-concept unfolds gradually and identity formation is a process that evolves over time. Although evidence indicates that people match or implement their self-concept in choosing an occupation, one's selection of an occupation does not take place at a single point in time. The choice of an occupation can be considered a developmental process that evolves over time and the decision to pursue a particular occupation is really a series of decisions that span a significant portion of one's life. The developmental approach takes into account that career choice is not just a single static decision, but, rather a dynamic development process, involving a series of decisions made over time. In common with other theories are the assumptions that "career choice is a derelopmental process beginning in cbildhood; ociupational aspirations reflect people's efforts to implement their self-ioncepss; and sati.jaction with career choice depends on bon well the choice fits the selfconcept," (Super, 1992, p.59).

\subsubsection{Super's Theory of Career Development}

According to Super's theory (Super, Savickas \& Super, 1996) people move through five stages relevant to carcer development: growth, exploration, establisbment, maintenance, and decline or disengagement which correspond with the life stages of childhood, adolescence, adulthood, middle adulthood and old age and their approximate ages. 'The order of these stages is not fixed, and the ages at which these transirions are made are also flexible. This theory has two primary dimensions, that is, time and space. Individuals develop over time through psychosocial maturation and cultural adaptation. The pattern of career development is therefore 
determined by individual characteristics in relation to social opportunities and constraints. People select occupations that best express their identities and satisfaction.

\subsubsection{Gottfredson's Developmental Model}

Gottfredson (1981) presented a developmental model of four stages beginning in early childhood and ending in late adolescence. The first three stages involve the climination of undesirable options. This process is known as circumscription, which involves a narrowing down of occupational alternatives. The final stage is characterized by compromise, which is modification of aspirations to adapt to reality constraints.

During these stages, individuals become more self-aware and narrow in their occupational options by eliminating those that are no longer acceptable. This theory views not only an individual's self-concept, but also, the barners as predictors of occupational choice. Selfconcept compromises many elements, including those that are vocationally relevant, such as "gender, social class background, intelligence, and vocational interests, competencies and values" (Gottfredson, 1981, p.548). Self-concept is defined as one's view of one's self, including physical appearance, abilities, personality, values and place in society. Self-conceptions determine the occupations that people choose. Individuals prefer occuparions that fit with their self-concept. People also compromise due to anticipated barricrs. The range of acceptable occupations is termed the social space, which reflects where people want to fit in the society (Greenhaus, 1996; Patton \& MacMahon, 1999).

\subsubsection{Occupational Choice as a Decision-Making Task}

We have seen how occupational choice can be viewed essentially as a developmental process in which experiences and increasing maturity enables a person to develop, modify and clarify the self-concept, gain further insights into the world of work, and attain a match between a chosen occupation and one's self perceived interests, abilities, needs and values. Given a set of alternative occupations, how does one choose which occupation to pursue?

According to expectancy theory, it is assumed that people approach an occupational choice situation with a fairly well established set of desired outcomes or rewards. Next, expectancy theory assumes people examine a number of occupations and determine the likelihood that 
each occupation will provide them with each job outcome. An individual's instrumentality perceptions, is assumed to be mentally rated on a scale. (Greenhause, 1996)

Expectancy theory assumes that individuals will mentally multiply the value of each outcome by the instrumentality for that outcome to obtain a total attraction score. A person is predicted to be most attracted to the occupation with the highest score. However, finding an occupation attractive is not the same as choosing to enter an occupation. There may be many attractive options (for example, professional athlete, brain surgeon, rock star) that we ultimately reject for one reason or the other. According to the expectancy theory, people develop expectancies regarding the likelihood that they could successfully enter a particular occupation if they put forth sufficient effort. Expectancy theory assumes that people mentally multiply the attractiveness of an occupation by their expectancy to enter the occupation. They then choose the occupation with the highest expected attractiveness. In other words, we are most likely to pursue an occupation that we not only find attractive but also have a decent chance of entering.

Do people really choose occupations in such a rational, calculative manner? Do people compare occupations on a long list of potential job outcomes, multiply the value of each outcome by its perceived instrumentality, and choose occupations that maximize the likelihood that they will obtain desirable outcomes and avoid undesirable outcomes? A growing body of research indicates that our occupational preferences and decisions do seem to be guided by our desire to seek maximum rewards from work (Greenhaus, 1996).

\subsubsection{The Systems Theory Framework (STF)}

In acknowledgement of the fact that no single theory is comprehensive enough to account for the complexities of human behaviour, an eclectic or a systems approach is often used to conceptualise the occuparional choices of individuals in this study.

The Systems Theory Framework (STF) identifies two broad components of career choice or development theory: content and process. The content influences in the framework are the individual system and the contextual system. Under content, the framework identifies variables applicable to the individual and to the context, thereby outlining key influences on career development. Linder process, the framework identifies the existence of interactive processes 
within the individual and within the context. This recursive interaction contributes to the micro-process of decision-making and the macro-process of change over ime. Finally the process component of the framework identifies the relevance and importance of chance. The framework is presented according to these elements to demonstrate the components of a system theory perspective on career development, their inter-relationship and their contributions to wholeness (Patton \& McMahon, 1999).

\subsubsection{The Individual System}

The individual is the centre of the career choice and development process. Several developments encouraged the active involvement of the self. These included the practical work of Holland (1973) in developing the "self-directed search" which encouraged individual involvement in the career decision-making process. The theoretical work of Bandura (1986) in developing the concept of self-efficacy emphasized an individual's ability to act on his or her environment rather than merely responding to environmental experiences. This perspective has been mirrored in the work of Vondracek, Lemer and Schulenberg (1986), who emphasized the uniqueness of the individual and his or her context and the resultant uniqueness of the interaction between each individual and that context.

Miller-Tiedeman and Tiedeman (1990) extended the view of individuals as constructors of their own lives, asserting that "life-career" or what Hall (1996) called the "protean career" needs only to make sense to the individual. In his Archway model, Super (1990) identified the person as the central component, or keystone."Super used the term self in his model. The STF prefers to use the term individual to suggest the uniqueness of a person and his or her situation. Thus the centre of the SIF is a circle representing the individual. The circle contains a range of intra-personal features influencing carecr development that are possessed by all individuals but are different for each individual. 


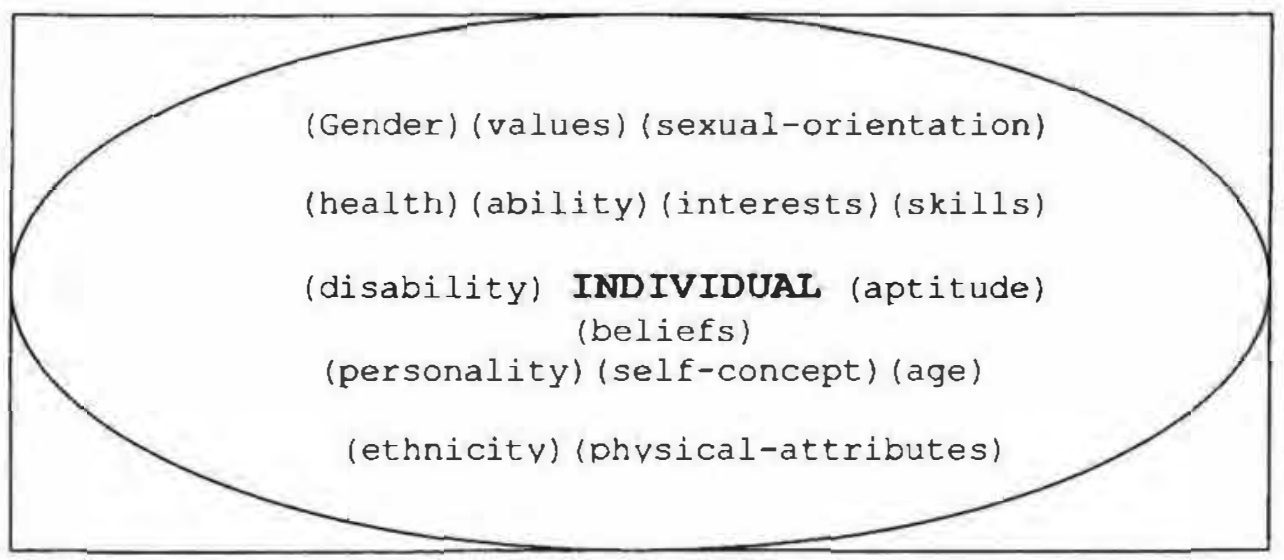

Figure 1: The individual System: Intra Personal Influences Source: (Patton \& McMahon, 1999, p.157)

The individual system (see Figure 1, abore) is composed of several intra-personal content influences or factors, including gender, age, self-concept, health, ability, disability, physical atributes, beliefs, personality, interests, values, aptitudes, skills, world-of-work knowledge, sexual orientation and ethnicity. Many of the influences represented in the individual system are represented in existing career theories. In this study, the following inka-personal content influences or factors were explored: age, gender, interests, aptrudes and self-knowledge among others.

\subsubsection{The Contextual System}

An individual as a system does not live in isolation, but rather as part of a much larger system. Thus the individual as a part of a larger system coexist with a broad contextual system that is itself composed of smaller subsystems. The broader system is broken into two subsystems, the social contextual system (the other people systems with which the individual interacts) and the environmental/societal contextual systems - the environmental and society.

\subsubsection{The Social System}

Influences representing the content of the social system (see Figure 2, on next page) include pecrs, family, media, community groups, the work place and education institutions. Each of these social structures is also the source of values, beliefs and attitudes that may be conveyed to the individual in a variety of ways. The influence of these groups can be long lasting and can vary over rime. 


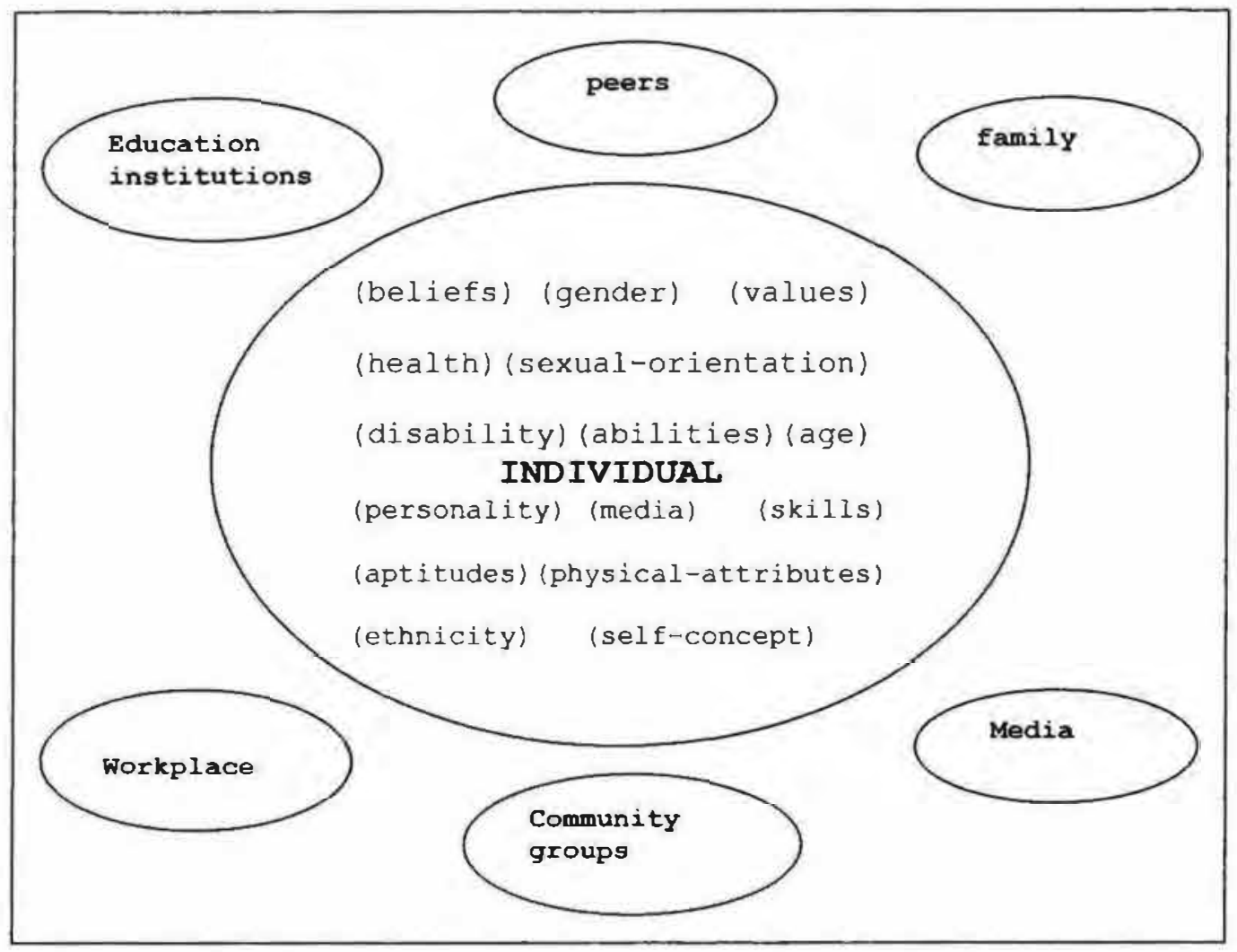

Figure 2: The Social System

Source: (Patton \& McMahon, 1999, p.159)

The composition of the social systems will change throughout life as the individual moves int• and out of groups - for example changing schools or jobs or moving to a new town thus, it is essential in considering the social systems of an individual, to explore the exact nature of the systems within, which he/she exists (Patton \& McMahon, 1999).

\subsubsection{The Environmental-Societal System}

The individual lives within a broader system, that of seciety or the environment. Environmental/societal systems (see Figun 3, on next page) influences include: political decisions, historical trends, globalization, søcioeconomic status, the employment market, and geographic location. These influences may seem less directly related to the individual, yet their influences can be profound. Many of these influences have been highlighted in the work of a number of career theorists (for example, Lent, Brown, \& Hackett, 1994; Mitchell \& Krumboltz, 1990; Roe \& Lunneborg, 1990). 


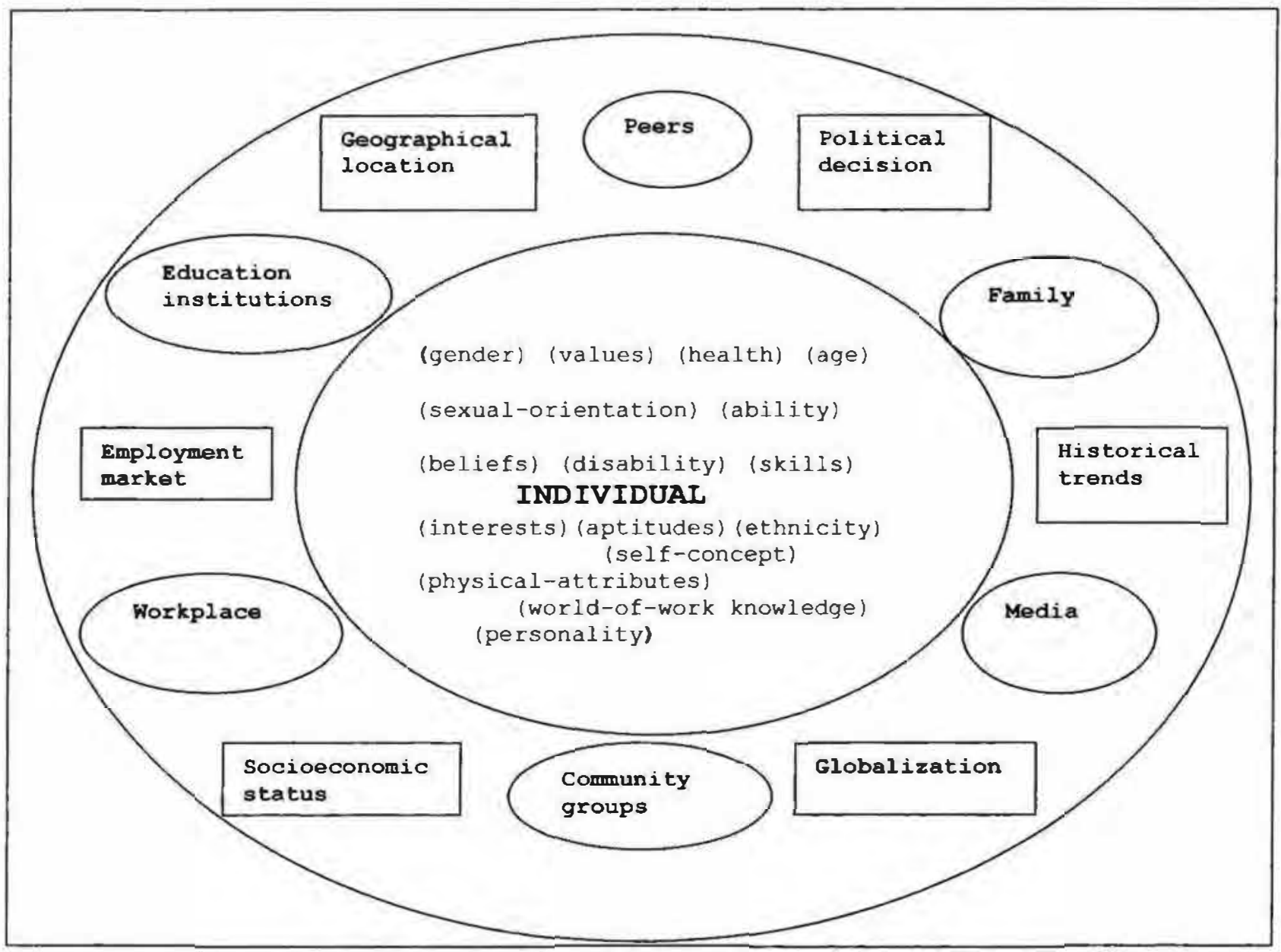

Firgure 3: The Environmental-Societal System

Source: (Patton \& McMahon, 1999, p.160)

\subsubsection{Chance}

Chance is defined as "an unplanned event that measurably alters one's behaviour" (Miller, 1983, p.17) and can be referred to as luck, fortune, accident, or happenstance. Mitchell and Krumboltz (1990) included genetic endowments as an occurrence of chance. Chance can affect any part or combination of parts of the system. For example, an accident or illness may produce a disability, a chance meeting may open up new unemployment prospects, and a "man-made" or natural disaster may reduce or increase job opportunities.

\subsubsection{Change over time}

Career development is a lifelong phenomenon (Super, 1990); Vondracek, Lemer \& Schulenberg, 1986) that involves ongoing decision-making. Thus, change over time refers to decision-making processes and accounts of change over time. The path of career development 
is one of constant evolution and may incorporate forvard and backward movements. This evolution is referred to in the extant theory as "emengent carver dectivion making" by Super (Freeman, 1993), "successive approximations" by Holland (Freeman, 1993), and "mini-decisions" (Patton \& McMahon, 1999).

\subsubsection{Recursiveness}

The emphasis on the systems theory is on the recursiveness, or ongoing relationships, between elements or subsystems of the system and the changes that occur over rime as a result of these continual interactions (Patton \& McMahon, 1999).

\subsection{SECTION 3: CLOSING COMMENTS FOR THE CHAPTER}

Given the diverse and complex range of influences and theoretical perspectives on career development, it is probable that no single theory can be comprehensive enough to adequately account for the career development of all individuals in all epochs. Corcy (1991, p.426) claimed that, "eclecticism should be thought of as away to harmoniously blend theoretical concepts and methods into a congruent frumework." Systems theory is well established in other fields such as family therapy but is relatively new to career development theory. The application of the systems theory to career development allows the disparate concepts addressed in the literature to be drawn together into one theoretical framework. As the important contributions of all career theories can be recognized, this study uses a systems theory framework to explore the factors that influenced carcer choices of learners from previously disadvantaged high schools. 


\section{H A P T E R 3}

\section{REVIEW OF LITERATURE ON CAREER DEVELOPMENT}

\subsection{ORIENTATION TO CHAPTER THREE}

This chapter is a continuarion from the previous chapter, which reviews literature. This chapter aims to further clarify issues around factors influencing career choices/development, which will provide a lens towards understanding the career choices of individuals and towards providing the answers to the purpose and the crirical questions in this study.

The purpose of this study is to identify the factors impacting on career choices of first year technikon students from previously disadvantaged high schools. 'The critical questions are:

- What are the social, educarional and personal factors that influence the career choices of technikon students from previously disadvantaged high schools?

- Do the respondents consider they had effective guidance programmes in their previous high schools?

- What role does the student counseling and development center in their current instintions play, in aiding the first year students, with regard to career choice difficulties.

To be in line with the title of this research it was thought necessary by the researcher to consider the following four points, that:

- Firstly, no single theory or model can be used to explain all factors impacting on career development of each individual.

- Secondly, it is important to explore as many as are availahle all theories or models designed to explain career development and the factors associated with it.

- Thirdly, a study of this nature demands a comprehensive data from all aspects, which may be impacting on career choice or development.

- Fourthly, with going all out to obtain as much information as possible also goes with the use of as many data gathering strategies as possible, resulting in triangulation of data. 
Career development as a process has been researched and described by many auchors (Super, 1957; Tiedman, 1963; and Krumboltz, 1976). Many vocational psychologists believe that vocational choice is an expression of the total personality. The cboice of a vocation is not a single event that takes place at a certain time but rather a result of a developmental process (Zytowsky, 1968). Although career development is a complex process to describe, Tiedman $(1963$, p.4) refers to career development as, "an orientation towards work that evolves within the psychological process of forming an ego-identity". It is self-development related to choice, entry and progress in educational and vocational pursuits.

From a theoretical perspective, the framework provided is largely exploratory and absolute relevance to South $A$ frica is not implied. However, features of theories and models have been alluded to, where applicability has been discerned in terms of career choice/development in the local context.

SECTION 1: Career Education and Guidance Factors in South African Context

SECTION 2: Factors That Guidance Educators Need To Be $A$ ware Of

SECTION 3: Closing Comments

\subsection{SECTION 1: CAREER EDUCATION AND GUIDANCE FACTORS IN SOUTH AFRICA}

Having examined career development theories and decision-making models it is necessary to review further, research literature related to the present study. The literature review in this section aims to make clear issues around factors influencing career choices by focusing on career education and career guidance developmental factors in the previously disadvantaged schools in South $A$ frica.

\subsubsection{Career Educational Factors in South Africa}

Watson and Stead (1999) contend that there is lack of theorerical models that have been developed to clucidate Souch Africa's various population groups. This is also true with regards to factors impacting on career choices of learners from previously disadvantaged schools. According to Stead and W'atson (1999, p.163) career education in South Africa has traditionally been located in career guidance acrivities which have been offered in a limited number of 
contexts: in some secondary schools, in career services of some tertiary education institutions, and in certain non-governmental organizarions (NGOs). Career education has not been accessible to the majority of people in need of it (Stead \& Watson, 1999, p.163). This lack of accessibility can also be considered as a factor impacting on career choices of learners from previously disadvantaged high schools.

Career education practice in South Africa still reflects the marked inequalities which, characterized apartheid education structures. It has been furthet curtailed or discontinued as the present monetary constraints in both formal education and former NGO structures impact on staffing and resource provision. In the school sector, so-called 'non-examination' subjects have been the first to be cut back and career education, as part of School Guidance, has all but disappeared in most schools. Many NGO agencies, which provided career services in the past, have also been forced to close for financial reasons. Yet, there are few compensatory governmental structures to assume these tasks, other than the overstreched and financially constrained Department of Labour. (Stead \& Watson, 1999, p.163).

The present career education situation must be juxtaposed with the growing number of research projects which underline the call of both learners and educators in secondary and tertiary settings, as well as representatives of labour, commerce and industry, for morc coherent and carefully planned career education progtams (Stead \& Watson, 1999, p.163). Akhurst and Mkhize (1999) believed that it is of vital importance for career education to be contextualised differently in South Africa, since it has a potential to make a positive contribution to the development of people, and thus to the economic development of the country'. They also indicate clearly their aim to convince us that it is necessary for career education to assume a far more central role in educational settings and other places where leaming takes place. They also point out that if a developmental perspective is to be followed, career education should begin in schools and then proceed into the workplace, tertiary institutions, other adult education contexts, and into the broader community. (Stead \& Watson, 1999, p.163)

Many studies have established the status of career education for blacks - strategy use, and theory base - in South Africa, (e.g. Dovey, 1980; Mtolo, 1996; Chuenyane, 1983; Ntshangase, 1995 and Pryor, 1985) and they have attested that in many black schools there is little or lack 
of access to career education services. Akhurst and Mkhize (Stead \& Watson, 1999, p.168) indicate that, "the question that needs to be asked is how South $A$ frican adolescents are positioned to meet the challenges of the twentieth century (simultaneously with rectifying those imbalances created during the apartheid era). Various studies in South Africa have emphasized the need of young people for career education. Chuenyane's (1983) study indicated that about $90 \%$ of the black secondary school population had 'serious career planning problems' (p. 278). This has also been underlined by a number of studies in the last decade (e.g. Mtolo, 1996; Ntshangase, 1995; Skuy, Hoar, Oakley-Smith \& Westaway, 1985), where learners have pleaded for career education in secondary schools. Unfortunately, as Akhurst and Mkhize (Stead \& Watson, p. 161) attest, factors pertaining to financial constraints in education have severely hindered the provision of career education in South Africa. Indeed, the majority of South Africans do not have easy access to career education and this is particularly, but not only, the case in rural arcas and townships (the previously disadvantaged community settings).

Pryor (1985) states that learners who have experienced the following factors pose particular challenges for career educators:

- Iimited exposure to the world of work

- Iirtle access to career education services

- No knowledge of large tertiary institutions

- A narrow range of social contacts

Consideration of these four categories of leamers in the light of the context described above has brought realization that large numbers of South African youth and adults would fit into one or more of these categories, thus emphasizing the extent of the need for career education in this country and clearly pointing at some of the factors impacting on career choices of students from previously disadvantaged high schools.

Gladding (1992), pointed out that children must be made aware that there are choices to be made as regards career and that such choices must be made at an appropriate time in the future of their educational career. 'Thus, it is beneficial to children, especially those who live in areas with limited employment opportunities, to have a broad systematic program of career counseling' (Gladding, 1992, p.430). 
In the 1990's, there had been five evolving career development theories that emerged. "These theories show promise for future development, and should their constructs become morc carefully defined through research and assigned levels of importance, they will become more meaningful to the career counseling profession (Brown, Brooks \& Associates, 1996)" and other contexts of career counseling (including the schools) (Zunker, 1998, p.70).

The five evolving theories include:

- A cognitive information processing approach to career problem solving;

- Career development from a social cognitive perspective;

- $\Lambda$ values-based, holistic model of career and life-role choices and satisfaction;

- A contexrual explanation of career; and

- A summary of self-efficacy model

All these theories, even though they come from different perspectives, they support the notion that "it is through career education that all students and many adults can become aware and knowledgeable of career decision making processes and the means to access and interpret careet and occupational information to their benefit (Stead \& Nqweni, 1999)" (Stead \& Watson, 1999, p.161). Career education is a very broad field that has as its primary aim the facilitation of the career development of individuals. According to Ilerr (1995), cited in Stead and Watson (1999 p. 161), it is through provision of stimulation and other exploratory modes, that career education can also provide the context in which the occupational structures can be demystified and ways can be leamed by which to classify its' possibilities in personal terms of reference.

Career education therefore also plays a prominent role in providing career information by means of carcer libraries and computer assisted career guidance. Factors such as lack of career information, which impact on career choices of learners from previously disadvantaged schools, can therefore be addressed. South Africans live in a technological age where vast amounts of career and occupational information are available and where such information is regularly updated. The South $A$ frican context requires technologically assisred information to meet the needs of South $A$ fricans who are overwhelmed by social and occupational change. Kok (1995) mentions that the lack of information and appropriate technology often prevents 
sustainable community development. Even if people know what they need, a lack of knowledge of available resources and how to utilize them effectively easily creates passivity or disinterestedness (Stead \& W'atson, p. 161).

\subsubsection{Career Guidance Factors in South Africa}

"De Jong, Ganie, Naidoo, and Prinsloo (1994) described school guidance and counselling in black schools in South Africa as being characterized by marginalisation, discrimination, underresourcing and underdevelopment" (Nicholas, Pretorius \& Naidoo, 1999). The National Education Policy Investigation (1992) found that guidance and counselling services in South A frica had been neglected and did not exist for the majority of the people. The majority of the population in South Africa is from the previously disadvantaged sector of the total population, therefore, factors such as under-resourcing, underdevelopment, and non-existence of guidance and counselling services have an impact on the career choices of students from previously disadvantaged high schools.

In the National Educational Policy Act of 1967, legislation of a National Guidance Service for whites, guidance was viewed as an auxiliary service and was characteristically didactic, overtly moralistic and aimed at guarding the identity of whites. In white schools, however, there was a significant dichotomy in the implementation of this legislation, with English-medium schools adopting a liberal humanistic approach and Afrikaans-medium schools a fundamental pedagogic approach (De Jong et al., 1994). The impact of the particular educational sociopolitical context of career guidance needs is clearly demonstrated by empirical data. For example, the University of the Western Cape (UWWC) regularly administers a needs survey to all first year students. As a historically black University, UWC draws the majority of its students from the historically disadvantaged community. As such, this data provides some indication of the extent of career guidance/ counseling deprivation of black population. In a Table 1.1 (see chapter 1), an overview of first year university students' satisfaction with the guidance received at school level, as well as the number of first-year students experiencing problems in making career choices is indicated.

According to Table 1.1, in all four years the majority of first year-students indicated that they were dissatisfied with the level and extent of guidance received at school. The impact of, this 
inadequate guidance, is demonstrated by the number of first year students who are experiencing problems with making a career choice. 'The majority of respondents indicated that they were experiencing major problems in this regard.

This data provides some indication of the perceived career guidance needs of black students, a need that is further substantiated by the various needs assessments undertaken among black students. A summary (see Table 1.2: chapter 1) of some of these needs assessments, indicated clearly that there is absence or inadequate career guidance programmes in the previously disadvantaged sector of the South African population, in particular.

Despite these consistent indications of where the greatest need exists, in terms of career guidance, a review of research on career counseling shows some surprising trends:

In general, published reseatch was found to be lacking. In their review of research conducted in South Africa between 1980 and 1990, De Brin and Nel (1996) could find only 22 published articles (i.e. $14 \%$ of all resources reviewed). As indicated by Nicholas (1997), this lack of published research impoverished the knowledge base that informs changing counseling practices.

There is a noticeable bias in favour of white samples more than $50 \%$ of the research undertaken focused on white samples.

In their review of career research in South Africa from 1980 to 1997, Stead and Watson (1998) point out the following:

- prior to 1990 , career theories developed in the LSA were accepted without question, by South African Researchers. Since 1990, however, researchers have started to question the appropriateness of these theories.

- Research on carecr education has largely been conducted at tertiary institurions despite indications that it may be even more important at school level. 
- Although some work has been done on examining the psychometric properties of intemational carcer instnuments, very little original instrumentation has been developed in South Africa.

Many researchers have responded to the call for relevancy by increasing the diversity of their samples. Stead and Watson, however, cautioned that the inclusion of more black samples in research does not in itself deal with the issue of culture. (Stead \& Watson, 1998, p.7-9).

On the other hand, Kekana $(2003$, p.2) pointed out that factors such as the lack of career guidance and counseling for the black (previously disadvantaged) youth in South Africa has resulted in a number of problems (negative impacts) that include:

- making wrong career choices,

- high failure and drop-out rates, and

- moving from one course to the other at teriary institutions

Students who seek counselling at Career Counselling and Development Centres in educational and other institutions ate at different levels of vocational indecision and educational indecision. Several studies done in South Africa (Smith, 1993; Van Vuuren, 1991; Watson \& Allan, 1989; Stead \& Watson, 1990) have examined the career development of high school pupils, taking into account role salience, career decision-making skills and career development across cultures. To date, very few of the South African studies have empirically investigated the relationship between vocational indecision and educational indecision.

It ought to be reiterated that guidance and counseling is important for $\Lambda$ frican pupils as an integral component of quality education. To the extent that guidance and counseling included in the school curriculum of some of the African schools, pupils are being denied an opportunity of becoming better men and women in their future life. The school counselor is interested in the development of the whole person. For this reason, the focus of guidance goes beyond addressing educational problems that pupils experience and includes personal, social and vocational issues. Such an approach contributes to pupils' personality development and their potential to experience a more meaningful, fulfilling and prosperous life. 
It will take a while before guidance and counseling is made available and accessible in all African scheols. But, we need not wait until this happens. Teachers who have had access to psychology, educational psychology and other behavioural science courses can play the role of counselor in addition to their teaching responsibilities. This may serve as short-term solution while the problem is addressed more thoroughly" (Mwamwenda, 1996: 473 - 474).

\subsubsection{School Guidance and Careers Educational Factors in Perspective}

The environment in which previously disadvantaged learners (black learners in particular) grow has an influence on the development of their interests. In South Africa it is well known that, their peers and parents often influence students that enter tertiary education in their career choices. Poor academic achievement, high failure rates, inadequate facilities, lack of or poor career guidance, excursions and career exhibitions, lack of textbeoks and under-qualified teachers are some of the factors that contribute negatively to the life of the learners. The school, teachers and career counselors have an important task, which is, to motivate learners (Kekana, 2003,p.70).

Palmatier (1998, p.484) indicates that it is all about removing the barriers that limit schools in their primary mission of teaching students who want to learn. He also pointed out his wish for teachers to take heart, to work together, to obtain the material support and moral support that they need and deserve, and to enjoy the challenge and privilege of relating to younger human beings who embody the future.

Schools have a commission to guard a sacred trust - their country's children and youth. But no institution can merely house people. For good or ill, some change in those people is inevitable. The normal course of events in school is not therapizing youngsters but creating the conditions in which they can develop favorably and leam basic and creative topics and skills. Whatever schools do will have an effect, one way or another. Results can be useful, so-so, or damaging. According to Vaughan $(1970$, p.57) career guidance during the last year or somerimes even the last term of school life, may be described as crisis counseling, a term also used to describe any last minute attempt at guidance. 
Vaughan (1970, p.105-106), pointed out that in reading the literature on counseling one gets three aims:

1. firstly, to create a self-reliant person, who, understanding his swengths and weaknesses, is able to make decisions without the help of a counselor;

2. secondly, to help individuals to adjust satisfactorily to the society and probable personal futures; and,

3. thirdly, to ease the work of teachers in schools.

According to Vaughan (1970, p.105) Williamson (1965) for example, suggests three aims:

a) to help the individuals order their experiences;

b) to help them define their goals;

c) to help them define their values.

He also points out that Tyler (1961) speaks of counseling as a process of helping people to make realistic choices and to improve their social relationship. She implies that this is to be done through increasing the self-awareness; as this improves, he becomes better able to make choices in a consistent manner, from which a pattem gradually develops (Vaughan, 1970, p.105).

Ruth Strang (1964) stresses the close relationship between education and guidance, as being two interwoven processes; she sees guidance as helping the individual to use his higher resources, and to direct his own goals, not just to solve problems. Thus she sees the guidance specialist as having a place both in primary and in secondary education (Vaughan, 1970, p.105106). "Miller sees guidance as having in the past sometimes become widened to include education itself, ingeswing the wider role without digesing it. In this way, Miller feels it may be in danger of losing its own identity. Williamson recognizes the need for counseling to help the individual and also to help State planning for a continually available labour supply, although stressing the right of the individual to his own choice of wotk." (Vaughan, 1970, p.107-108). 
The Human Sciences Research Council in collaboration with the Department of Labour, had developed a computerized career guidance programme as a means to effectively use human potential (Beneke, 1994, p.1), however, due to the past political setup of our country, these programmes were not exposed to learners in black schools. In South A frica, the Soweto riots in 1976 in which black youths expressed their extreme fnustration with schooling for blacks was a major contributing reason for the introduction of a career guidance service for young blacks in schools. This led to the compilation of syllabi aimed at providing the needs of black youth in relation to their personality, social, educational and career development (Kekana, $2(003$, p.6). Although secondary schools do provide learners with basic information about careers and the institutions that offer these careers, there is a need for a systematic career assessment that includes the assessment of aptitudes interests and personality. Such systematic are non-existent in black secondary schools. This is because in South Africa, career guidance and counseling has been less illustrious and more contentious.

Specialised career guidance has become more important in our complicated career world. A simple matching of men and jobs according to the Parsons model (1909) is no longer effective (Zunker, 1998, p.9). It has become a long and difficult process to make a reliable career choice where a person can be udilized to his/her full potential. Baijnath (2003, p.2), in her study, highlighted the following points, which are very important and understandably significant contributors toward difficulties in choosing careers for young people. These are the factors within the environment, impacting on career choices of individuals. They indicate that:

1. Our school svstem is not designed to introduce learners to the realities of the world of work

2. Our universities are academic institutions and do not sec themselves solely as job factories

3. The human being is capable of operating in a number of different fields successfully

4. No personality preference or aptitude tests are sophisticated enough to produce perfect pointers to specific jobs

5. "Correct" career decisions are dependent on a host of variables such as vocational maturity, accurate information about the field of study, the world of work and selfunderstanding, and, rely on processes rather than one-step operations 
Given the pressures on young people to make early occupational choices, many become anxious about choosing the "right" field of study and career. According to Gibson (2000), "when one considets the five points listed above, it is understandable, that many successful young Grade 12 leamers (matriculants) find it difficult to make quick, seemingly final and accurate career decisions" (Baijnath, 2()03, p.2).

With adequate counseling programs in the schools, this situation could be prevented. Lindhard (1987, p.179) identified essential clements of a careers education programme which schools need to implement to help leamers choose careers and to provide them with the skills, attitudes, and knowledge useful for survival and progress in their chosen jobs. According to Lindhard a careers education programme teaches a student the following:

- self-awareness

- educational awareness

- cateer and job awareness

- decision-making skills, and

- employability awareness.

Box 1: A Summary: Lindhard's essential elements of a careers education programme

\section{A CARRERS EDUCATION PROGRAMME TEACHES A STUDENT}

- self-awareness: knowledge about himself, his interests, abilities, aptitudes, etc.

- educational cowareness: knowledge of the education and training available to him

- career and job cowareness: knowledge of the jobs and careers covailable, and their entrance requirements

- decision-making skills: how to make a choice of career and job

- employability awareness: knowledge of what is expected in the world of work

\section{SOURCES OF INFORMATION FOR THE TEACHEER ARE}

Books, magazines, pamphlets and leaflets containing information, newspapers, university and college prospectuses and calendars, professional careers advisers and organizations, class and personal visits to firms, institutions, etc.

Source: Lindhard (1987, p.179) 


\section{THE CAREERS EDUCATION PROGRAMME}

In the Careers Education programme the teacher teaches the students to find his own answers to these questions:

Self awareness

What can I do

best? What do I

want most?

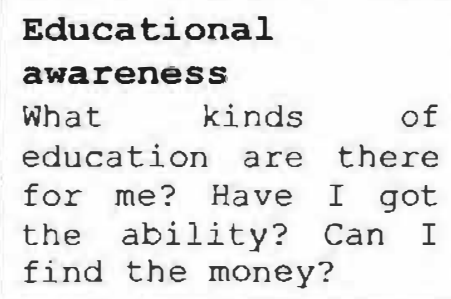

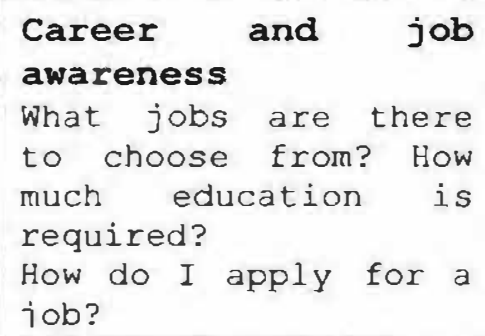

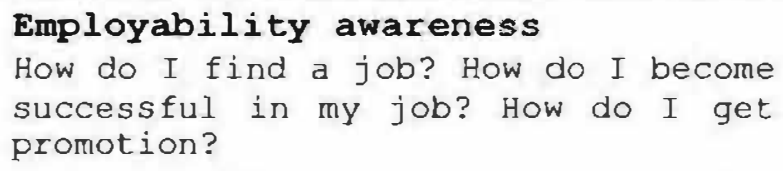

Source: Lindhard (I987, p. /82)

McKinney (1958, p.358) also pointed out that vocational counseling cannot be a purely mechanical process of determining an individual's status on various tests and dispensing advice as to what vocations are open to him. Vocational preference and competence reflect personal development. For the active growing person, the selection and development of a career extend over a long period of time. It has been said that an individual's thoughts about vocations progress through stages. The earliest is the fantasy stage. Later, with exploration, the individual decides on a tentative vocation and with increasing information becomes more realistic in his exploratory thinking. As he grows in maturity, his vocational preferences and plans become more stable, but the process is always dynamic and changing. The maturation of one's vocational preferences is in part related to the maturation of one's abilities and interests. Each shift in vocational preference is a step in the process of testing reality. The student's later 
choices are a compromise between his individual traits and social factors, as well as between his conception of himself and reality. This process goes on with or without counselling. With adequate counseling, however, the final compromise could be more realistic and stable. McKinney (1958, p.358).

Happily, in ether directions, such as choice of career, important evidence about the degrec of success, which the school is achieving, can be gained from a systematic review of the information available in the records of the school's careers advisory service. How many children leave school as soon as they are entitled by law to do so, and how many of them were, in the school's judgment, mistaken in that decision because it was taken contrary to advice and persuasion. Such data, seen against the schøol's background of geography, community attitudes and job opportunities, will throw some light upon the effectiveness of the school's curriculumn, syllabuses and teaching methods, upon the extent to which the children's interest has been aroused and upon the degree to which they have become willingly involved in their own intellectual, educational and social development. McKinney (1958, p.358).

As part of career development, pupils ought to be exposed to oppotwunities involving selfexploration and assessment, identifying occupational roles and models, developing insight into the relationship between these aspecrs of one's own values and attitudes (Woody, 1989). By junior secondary level, career development becomes more differentiated (specific) and the focus shifts to the relationship between occupational goals in relation to specific interests, values, abiliries and personality characteristics. Provision should therefore be made regarding career development and the courses which match certain work opportunities in various areas. 'Assets that students should become more aware of and begin to evaluate include talents and skills, and general intelligence, motivational level, friends, family, life experience, appearance, and health (Gladding, 1992, p.431)'. As adolescents approach the completion of their studies, they should be provided with information relating to actual jobs available and the qualifications needed to apply for such jobs.

Providing career education to adolescents is a multiphase responsibility involving not only the counselor, but also parents, community members, and others in the actual working world. It ought to be reiterated that guidance and counseling is important for African pupils as an integral component of quality education. "To the extent that guidance and counseling included 
in the school curriculum of some of the $A$ frican schools, pupils are being denied an opportunity of becoming better men and women in their future life" (Mwamwenda, 1996, p.473). "The school counselor is interested in the development of the whole person. For this reason, the focus of guidance goes beyond addressing educational problems that pupils experience and includes personal, social and vocational issues" (Mwamwenda, 1996, p.473). Such an approach contributes to pupils' personality development and their potential to experience a more meaningful, fulfilling and prosperous life. The researcher shares or agrees with the view that it will take a while before guidance and counseling is made available and accessible in all African schools. But, we need not wait until this happens. Teachers who have had access to psychology, educational psychology and other behavioural science courses can play the role of counselor in addition to their teaching responsibilities. This may serve as shortterm solution while the problem is addressed more thoroughly" (Mwamwenda, 1996, p.473 474).

\subsection{FACTORS TO BE CONSIDERED BY EDUCATORS INVOLVED WITH GUIDANCE AND COUNSELLING IN SCHOOLS}

\subsubsection{What is Guidance?}

An effective guidance teacher has to have knowledge about guidance. Knowledge about guidance, for guidance tcachers, is a factor that has an impact on the career choices of learners. It is a responsibility of all teachers to have some guidance skills no matter how medest. According to Beerlall (1997), and Bhamjee (2001), teachers' influence is counted amongst the factors influencing career choices of learners in their studies. According to Claudia Regnart "Guidance means teaching reality to the young" Lindhard (1987, p.1). Lindhard (1987, p.1) went on to point out the following, about guidance:

- it is an activity in which the teacher brings children into contact with the world as it really is, and helps them to make choices wisely in their day-to-day lives

- it teaches you to know yourself

He further elaborated that guidance helps the pupil or student to develop. He went on to state that if the student has no guidance, it is likely that his/her development will take longer. He also pointed out that guidance must be directed at increasing self - knowledge and insight of 
learners. "A student can be helped to discover this knowledge in the classroom, thus saving him/her - and sometimes the pain - of doing it the hard way. The teacher needs special knowledge in order to be a good Guidance teacher: she needs to know what should be taught in guidance lessons, she needs to know how to do it and she needs to be a deeply caring person. She must care that her young pupils grow up to be mature and responsible individuals." (Jindhard (1987, p.182). Factors such as the availability of guidance at school can afford learners with an opportunity of increased self-knowledge and insight.

\subsubsection{Different Areas (Factors) Addressed by Guidance}

Among the many factors that impact on career choices of leamers from previously disadvantaged high schools are those which are; personal, social, educational, and, vocational; in nature. These factors have an impact/influence unique to all individuals, depending on each individual's circumstances. If the school offers guidance, the chances are greater that such factors can be dealt with at the appropriate stages in the learners' development. As for those learners who lack guidance at school, the chances are greater that these factors may impact negatively in their choice of careers, if they remain unattended at the time they actually make their choice.

According to Lindhard (1987, p.4), Guidance is normally given in four different fields: personal, social, educational, and vocational

- Addressing personal factors: In the personal field, the Guidance teacher's first job is to help the student know themselves: they must know their strengths and weaknesses, their abilities, and they must recognize their values, which are the standards that a person sets for himself and by which he judges others. The traditional values and cultural of the old African societies - honesty, humaneness, a sense of community, and independence in its unselfish form - are some of the values and cultural traditions which the Guidance teacher must pass on to students. People also need to know about their personalities, how others see them, and how they affect others: are they confident or timid, forceful or weak, happy or moody, friendly or hostile all the time, sometimes or rarely? And so, of course, when a student has learnt about himself and his values, abilities, and personality he might ask: "How much of this can I change, how much do I want to change, and what cannot be changed?" The need for deeper self-knowledge becomes evident when we know that 
people who are indecisive are most often people who do not know themselves very well. A person who knows himself well will know how he will behave in situations involving other people. Mature decisions, are made by mature people with self-knowledge. One of the many definitions of maturity is that mature people will make decisions and take action using their own abilities rather than leaning on other people and using theirs. Maturity and self-knowledge lead to greater coping skills, which are skills of dealing with problems of life and living, for example, choosing a career. It has been said "that until you know who you are, you will not know what you can become". (Lindhard, 1987, p.4 - 5).

- Addressing social factors: In the soizal field the teacher has to prepare the student for the future when he will be an adult citizen. The child is already a member of the family circle and the school community, and he must be made aware of the role he can play in these two communities: how to live in peace and toletance with the people in them, and how to be a contributor to the community as a whole. Social relationships, good relations with others and social conduct are important aspects of guidance as a subject. (I.indhard, 1987, p.5).

- Addressing vocational factors: In the educational field the teacher has to give guidance on immediate problems such as study difficulties or the choice of the subjects most suitable for a student's abilities and future career. The teacher also has to give guidance in the area of further education after school. (Lindhard, 1987, p.5).

- Addressing vocational factors: Guidance in the wiational field, or careers guidance, means helping a person to choose a career, to find a job and to succeed in it. This requires a wide knowledge of the careers available, job situations, how to find a job, how to get it and how to keep it. All these things can be and should be taught at school in order to prevent too wide a gap between expectations and experience in the world of work. At times there is a great deal of unemployment and therefore not enough options for everyone. Then we have to think about working without a job, working for themselves, without an employer. (Lindhard, 1987, p.5-6).

It is common knowledge that some of the factors that impact negatively on career choices of learners can be overcome, if addressed at the appropriate time. Cuidance is obviously 
one of the measures that can be taken to address such barriers, provided it is sought or given at the correct time for it to be effective. It should also be given by an appropriately trained person in order for it to be effective.

\subsubsection{Factors Addressed by Counselling (Lindhard, 1987, p.6)}

Although the Guidance teacher will spend a great deal of time in the classroom giving guidance to large groups of students, she also has to give guidance to most of her students individually. Nearly all of them will need help and advice in choosing subjects, many will need information on further education and job opportunities, and quite a number will need help with personal problems. Counselling is personal assistance and guidance given to a student in an interview. $A$ teacher gives guidance to the child on his own and not in the classroom. The relationship now becomes a very personal one, and the teacher's responsibility for and guidance on the young person is very great.

Counselling can be described as a conversation in which one person helps another who has a problem. Often counseling is concerned with helping a person to make a choice or come to a conclusion, and the problem may very well be that a student does not know how to make a decision. The easiest way out of the siruation would be for the teacher to say, "Well, why don't you...." or, "If I were you, I would..." The rouble with this kind of solution is that such "if I were you" answers do not teach the student to make decisions in the future, and also, if the solution is not effective enough, who is to blame - himself or the teacher? This was why one of the pioneers of guidance and counseling, Leona Tyler, said, "Hard as it may be to give information without advice, it is this that one should usually attempt to do." 'The teacher's job is not to solve the student's problem by giving him advice; it is her job to teach the student to solve his own problems - those he has now and those he will meet in the future.

Of course, this suggestion can never be a final or exclusive one. There are situations where the older person must protect the younger person from doing silly things, which might harm him or her. The young one will expect an answer and should not leave empty-handed after an appeal for help. But situations in which a young person can leam to solve his own problems are more frequent than many teachers will think. A good question to ask a student who comes for help would be, "What do you think would be a good solution to your problem?" 
Counselling is an extremely important aspect of the Guidance teacher's work. (Lindhard, 1987, p().

Learners can use counseling to vent out the problematic factors (factors that influence their career choices negatively), that they may not exactly be comfortable to disclose in the open classroom environment. The counselor can then offer alternative measures in an attempt to address these factors. The counselors can also keep a database of what are the prevalent and common factors that impact on career choices of learners in their school.

\subsubsection{Factors Regarding Sources of Information for Guidance (Lindhard, 1987, p.6-7)}

A need for or lack of information has been attributed to as one of the major factors that impact negatively on career choices of leamers, however guidance classes can provide the desired information, which covers several fields such as the careers as well as planning for the education or training that is necessary for those careers. Guidance is based on giving information and, when necessary, teaching students how to use it. Students must leam how to make decisions: there are many important decisions that affect a person, and no amount of good information will help if the person does not know how to choose or how to make a decision wisely. This is why decision-making is one of the subjects in Guidance classes.

The guidance teacher needs to have a lot of information. lt is such a lot of information such that it would be unrealistic to expect the teacher to keep it all in her head. Much of it is available in books, in the regular notes from the departments of education, in the magazine (put together by Department of Education) and from various organisations that publish information on their activinies. The information covers several fields, the largest of which are the careers and educational fields. Planning for the future means planning for a career as well as planning for the education or training that is necessary for that career. Educational information includes knowledge of the educational and vocational institutions in which schoolleavers can prepare and train for their future careets. Such institutions range from universities and technikons at the tertiary level of education, to technical colleges, vocational training centers, and even institutions offering courses by correspondence. The teacher must know what courses are available at the various institutions, and what entrance qualifications required for the courses. (J.indhard, 1987, p.6-7). 


\subsubsection{Factors Pertaining Decision-Making at School (Lindhard, 1987, p.58)}

One of the major factors that influence the career choices of learners is decision-making. Before the students can make their choices they must first learn how to make decisions. This is why decision-making is one of the subjects in Guidance classes. Poor decision-making or lack of decision-making skills has a negative influence on career choices of people. When suddenly the student from a previously disadvantaged school is suddenly confronted with a task of making a decision, whereas, he/she has had to have decision made for him/her all his/her life, he/she may have difficulties in making a decision.

"Watch the tortoise! He makes progress only when he sticks his neck out" James Conant, cited in Lindhard, 1987, p.53). One of the most difficult tasks in Guidance is to teach decisionmaking in class. Most decision-making is learnt by, actually doing it, by making decisions. In the same way, driving a car is learnt by, actually driving. Nevertheless, no driver is safe unless he has read the rules of the road. The aims in teaching decision-making must be to make the students aware of what they do when they actually make decision, to raise their awareness of the importance of making good and well-considered decisions, and when they come to a really important decision, to encourage them to follow the systematic approach and understand the points in Box 3, below:

\section{Box 3: Lindhard's definition, influencers and principles of decision-making}

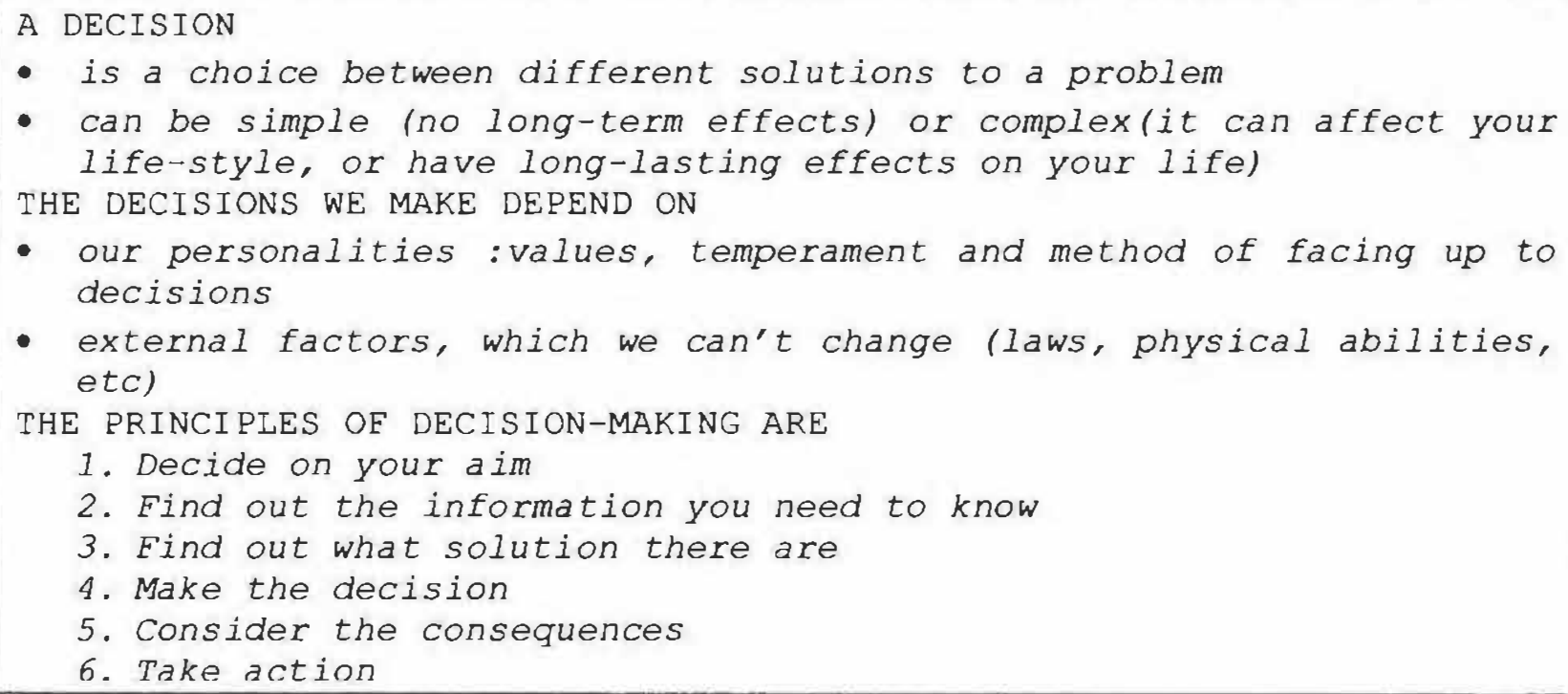

Source: Lindhard(1987, p.53) 


\subsection{CLOSING COMMENTS}

As part of educational guidance and counseling, the counselor will spend considerable rime exploring with the pupils the educational opportunities available beyond secondary school. While some will pursue university education, a greater proportion of pupils will seek admission into other tertiary institutions, such as colleges of education, agriculture, nursing, technology, business studies, computers and public administration. The counselor should ensure that such information is available and accessible to pupils. The counselor should also make sure that pupils know what courses are available in these institutions and what the prerequisites are for admission. The information should be as up to date as possible, and their addresses should be available so that pupils can write to them for information and admission. When pupils are applying for actmission, the counselor should assist in such a process if pupils need such assistance.

As pupils contemplate which institution to apply to, or what trade or profession to pursue, there may be conflicts between their choices and those of parents or peers. Pupils may also find themselves in a state of indecision about what they should choose. The counselor will have to counsel the pupils on an individual basis and come up with some definite decision bearing in mind that more than anything else, the counselor is a facilitator and therefore can only assist a pupil in arnving at his own solution to his problem. This is especially vital in view of many African pupils' perception of a counselor as an authority figure who is there to tell them what to do. This is not correct; he/she is there to find more effective ways to solve their problems.

In the selection of a career one may be faced with one or more of the following factors: (a) no choice, (b) uncertain choice, (c) unwise choice and (d) lack of match between interests and aptitudes. It is also possible for a client to experience the following influences in carecr choice:

- A need for vocational information

- There may be a conflict between the client and the significant others in the choice made.

- There may be self-conflict in the sense that the client may be interested in two or more carcers although he has to choose one. 
People who have not yet made the career decision may be categorized as either undecided or indecisive. Those who are undecided can resolve this state of mind by being provided relevant information regarding careers. People falling into this category could also be undecided because they are contemplating several options and aren't sure which one to choose. Indecisive people on the other hand, fail to commit themselves to a given career due to personal problems. Indecisive individuals fall into two major categories, namely those who have a low level of self-confidence when it comes to selecting a career, and those who experience a high level of anxiety about following their definite choice of a career" (Mwamwenda, 1996, p.469)

As part of such a programme, children should once in a while be made to undertake trips visiting different working areas such as banks, induswies, farms, business and commercial centers. They should also make it a point to ask individuals, including parents, to address them on the work they engaged in. Children should also be asked to list some of the occupations in which their parents, relatives and people they know engage. If possible, they should explain the nature of their work in detail. It would not be out of place to ask children to identify some of the work they would like to do and why. As part of such programmes, children should be told the principles governing work, and why there is need for people to work. Some of their work in class should be geared to activities involving work carcer" (Mwamwenda, 1996, p.473-474).

"Many concerns have been expressed in the literature about the wholesale application of models developed in other societies to African contexts (Naicker, 1994; Stead \& Watson, 1998). Criticism is that the theories and the assessment instruments derived from them are, to a large degree, influenced by Westem, individualistic values. Implicit in these theories and instruments is the assumption that an individual is a free and autonomous agent. For example, the term 'self-knowledge" is defined in terms of one's interests, petsonality, abilities and values (and a number of instruments exist to assess these). A conceptualization of self-knowledge in terms of an individual's unique attributes leaves out contextual factors that may have a bearing on the career development process. $A$ frican models of the person see embeddedness in ones family and community to be a definition of personhood par excellence. To be a fully functional person means promoting a harmonious relationship between oneself, one's family and one's community (Ikuenobe, 1998). The maintenance of a harmonious relationship comes with a 
number of responsibilities towards family and community, and one's career is usually seen as a vehicle for fulfilling such responsibilities.

The African belief 'umuntu nyumuntu ngatiantu / motho kemotho kabutho batiang' (it is through others that one attains being) therefore impacts on the career decision-making process. The importance of community in the career choices of African pupils is perhaps best demonstrated by their tendency to choose social and investigative-type occupations above others (Watson, Foxcroft, Hom,\& Stead, 1997). (One reason for such choices is that the social usefulness of such occuparions is easy to demonstrate. Furthermore, wisdom (in the sense of being a knowledgeable philosopher who offers others guidance in the ways of life) is highly valued in African life, as symbolized in the respect for the wisdom of elders. The value placed on wisdom probably accounts for the preponderance of sometimes investigative-type careers in the career aspirations of young Africans. Career education programmes therefore need to take into account the relationship between career and community if they are to be relevant in the African context.

A further strong criticism of many career education programmes is that the theories on which they are based were founded on middle-class conditions and possibilities. Such programmes have been undertaken by largely middle-class educators who have had little understanding of the issues and limitations on choices experienced by learners from disadvantaged backgtounds. The challenge in the last decade has been to develop more inclusive career education programmes, to reach out to minority groups, and to be more responsive to learners' contexts. In South Africa it is necessary for educators to be aware that the majority of learners were disadvantaged under the apartheid regime. There is an enormous task ahead, both in schools as in post-secondary education and in communities (Stead \& Watson, p. 171-172)".

"Among senior secondary school pupils, there is a definite increase in concern regarding vocational choice as they are about to complete theit education. There is also concem tertiary education that is relevant to prepare them for the kind of careers they wish to pursue. As choices of careers are made, there is often conflict of interests within a person. For example, $\mathrm{s} /$ he may be interested in more than one career and yet only one career can be chosen. An individual may also realize that despite his interest in a given career, s/he may not be admitted for various reasons. Such situations will call for a counselor to guide and counsel those affected 
so that they can resolve their conflicts of interest as well as finding and exploning alternatives for those who are unable to get admission to the programmes of their choice" (Mwamwenda, 199( $468-469)$.

This research also considers that, "externally, there may be conflicts between the pupil's choice and what peers may think s/he should be doing. Similarly there may be conflicts between the pupil's rocational choice and what his parents would like him to do. While the pupil has the right to choose the career he wishes, if such a choice is unrealistic in terms of his ability, personality, and job opportunities, then it is only fair that he be made to understand this. Counsellors can only guide and counsel pupils, but the final decision is theirs. In line with this conclusion, we should also bear in mind that: No single occupation is the one most suitable for an individual. Instead, individuals must make compromises among personality maits, interests, attitudes and values in making a satisfactory adjustment to work (Nugent, 1990: 143)" (Mwamwenda, 1996: 469). 


\section{H A P T E R 4}

\section{RESEARCH METHODOLOGY}

\subsection{ORIENTATION TO CHAPTER FOUR}

The previous two chapters surveyed literature both internationally and nationally in order to gain insight into the factors that influence carecr choices of individuals.

This chapter unfolds the research methodology used to identify the factors impacting on career choices of first year technikon (DIT) students from previously disadvantaged high schools. The critical questions being:

- What are the social, educational and personal factors that influence the carcer choices of technikon students from previously disadvantaged high schools?

- Do the respondents consider they had effective guidance pregramme in their previous high schools?

- What role does the student counseling and development center in their current institutions play, in aiding the first year students (from previously disadvantaged high schools), regarding career choice difficulties.

\subsection{RESEARCH DESIGN}

The aim of a research design "is to plan and structure a given research project in such a manner that the eventual validity of the research findings is maximized" (Mouton \& Marais, 1990, p.33). According to Goginsky and Collins (1996, p.381) research design is the basis from which study outcomes are obtained. Without a research design the study will lack credibility. It is further stated that, a well-designed study with results that are statistically significant is acclaimed as a contribution to the field in which it is taking place while those from a poorly designed one is considered inconclusive, even if it may be statistically significant. Sometimes the logic of a study, including the way research questions are framed, is clearly quantitative or clearly qualitative and that logic flows through naturally into the design, sampling, data collection and data analysis (Punch, 2000, p.51). A research that requires numeric responses is called a quantitative research Johnson \& LaMontagne, 1993, p.74) while one requiring responses that are non-numeric is a qualitative research (Polkinghorne, 1995, p.6). 
"These simplified definitions are useful for getting started in research, but they do not give the full picture of the quantitative-qualitative distinction. The term 'quantitative research' means more than just research methods, which uses quantitative or numerical data. It refers to a whole way of thinking, or an approach, which involves a collection or cluster of methods, as well as data in numerical form. Similarly, qualitadive research is much more than just a research method that uses non-numerical data. It too is a way of thinking, or an approach, which similarly involves a collection or cluster of methods, as well as data in nonnumerical form. The full definimions of the terms 'quantitative research' and 'qualitative research' would include:

- the way of thinking about the social reality being studied, the way of approaching it and conceptualizing it;

- the design and methods used to represent that way of thinking, and to collect data;

- the data themselves-numbers for quantitative research, non-numeric (mostly words) for qualitative research." (Punch, 2000, p.4).

According to Husscy and Hussey (1997) the structures of research are termed the research design. The concept research design refers to the architecture, strategy and tactics to be used in the research (Sackett and Wennberg, 1997, p.1636). The approach that was taken in this research project, and its ravionale are detailed below.

\subsection{RESEARCH APPROACH}

In this study, a combination of two research approaches (quantitative and qualitative) was used. The approaches were considered appropriate for this study given the diversity of information required to answer the research questions. The nature of the problem under invesugation required the use of both approaches, because the various methods give totally different kinds of information that complement each other. In this study, data was collected from different contexts (for example, different campus lecture halls, student counseling and development center, career resource library) and from different data sources (for example, the subjects (1" year students), psychologist, career resource librarian).

A sumey method was employed in this study to gather data. This method is one of the most widely used types of descriptive research in the behavioural sciences (Beerlall, 1997, p.29). A survey is a structural questionnaire, designed to solicit information about a specific aspect of a 
subject's behaviour (Weiten, 1989, p.45). It allows for the gathering of data from a large sample at a particular time and is concemed with overall statistics from which abstractions and conclusions can be drawn (Behr, 1973). The survey is a method of collecting data that can be used to fulfill both qualitative and quantitative approaches. This method was considered appropriate for the present study as it allows for generalizations on the study's population from the results. These generalizations can in turn be useful for career counseling purposes and in designing effective programmes. Interviews were also conducted with the careers librarian and the senior counselling psychologist.

Cohen and Manion (1980) refer to the use of two or more methods of data collection as triangulation. This method of data collection in the social sciences attempts to map out more fully the richness and complexity of human behaviour by studying it from more than one viewpoint. These methods were considered appropriate given the diversity of information required to answer the research question. The work involved in investigating factors impacting on career choices of first year technikon students from previously disadvantaged high schools is complex, expensive and time consuming. Thus a manageable sample of one rechnikon was considered reasonable and less expensive than using the entire population.

\subsection{PILOT STUDY}

The pilot study, which included the research questionnaire and the interview questions, was conducted with the students and the supervising lecturer respectively. The questionnaire was piloted on a small sample (10 respondents) of first year technikon students from DIT-D)urban. The group was chosen because of its similarity with the 'actual' desired sample of this study as well as easy accessibility and the close co-operation that exists berween the researcher and the institution. This was done as a pre-test to evaluate whether:

- Any questions are ambiguous or confusing

- The data being gathered is appropriate for the study

- The respondents consider the questions to be too long

- The respondents consider the question to be valid and appropriate 
The issues of reliability and validity were also part of the reasons for piloting the questionnaire. When the questionnaire was constructed the researcher considered the three types of validity: face, content, and construct validity.

The following aspects emerged from the pilot of the questionnaire:

$\therefore$ The questionnaire was too long.

* There were too many open-ended questions that were repetitions of the close-ended questions.

- Question 4.6 was considered to be ambiguous and unclear.

Question 2.2 a) which required students to state the approximate family income was considered to be problematic as respondents either did not know or did not want to divulge this information. The preferred terms to use were low, average, and high-income brackets. Further discussion with the pilot group led to the categorization of low income as earning salary of between less than between R1 000 and R3 000 ; middle income, R4 000 and R6000; and high income as being above R7 000 .

The following emerged from the piloting of the interview questions:

There were too many questions

Some questions asked for similar information (information that had already been requested by other questions in the same questionnaire)/repetitions

The above points that emerged from the pilot study were considered, and necessary modifications were made in the final instrument.

\subsection{THE SAMPLE}

\subsubsection{Setting and Research Sample}

In a survey, it is imperative that the sample used is representative in terms of demographic variables such as education, age, gender, and socio-economic status (Berryman, 1991; Igaga, 1990; and Zimbardo, 1992). As a result of having a representative sample, the tesults will not be biased, and therefore it will be possible to generalize such findings to the larger population from which the sample was drawn. 
The study was confined to the population of technikon first year students, from previously disadvantaged high schools, whose responses about experiences in choosing careers provided statistically significant and factual information. This means that the sampling procedure for this particular study was purposive in nature or random purposeful as it is sometimes referted to. Random purposeful adds credibility to sample when potential purposeful sample is too large. The sample frame comprised of first years at DIT (Durban Institute of Technology) in Pietermaritzburg (Riverside and Indumiso), a city in the Natal Midlands. The sample in this study consisted of 100 males and 100 females between the ages of 16 and 27 years who were first year DIT students. 25 males and 25 females from each of the four faculties were selected to participate in the survey in order to be adequately representative of the DIT (PMB) first year student population.

The choice of DIT (PMB) was mainly because it has a large leamer popularion, is easily accessible and offers a wide range of courses at technikon level. The large student population makes this institution a fairly representative tertiary institution in the Midlands in respect of the socio-economic level of leamers' parents and accommodation of students from previously disadvantaged schools in the region. The geographic location of this instiution is also an advantage, at the heart of the Kwa-Zulu Natal midlands.

The first year technikon students from previously disadvantaged schools in the Pietermaritzburg and Midlands area comprised the sample frame that the study required. $\Lambda$ s a result of the above points, the decision, which is in line with the ideas of Cresswell (1994) was made, to use a sample of first years in one technikon, thus converting the selected sample to a convenience, non-probability sample (Kekana, 2003, p.55).

\subsubsection{Missing Sample}

The researcher was unsuccessful in getting all questionnaires to be completed properly and a significant number were considered devoid. Twenty percent of the respondent did not retum the questionnaires. Due to these difficulties the final sample was reduced to 80 respondents (40 male and 40 female students). 


\subsection{PROCEDURE}

Arrangements were made, via the Student Counselling and Development Centre, with the lecturers, to conduct the survey. Times, dates and parricipants for the study were finalized and communicated to the various Faculties and Departments. The survey was conducted over three days during and after lecture hours in November 2004. The duration for completion of the questionnaire was approximately thirty-five minutes. The researcher administered the questionnaire and ensured that there was minimal disruption to the academic progtamme of the institution. 'The purpose of the study was explained to students and confidentiality, voluntary participation and anonymity were emphasized.

The interviews were conducted on the third day with the Careers Librarian and the Seniour Psychologist. The Careers Librarian was interviewed in the Careers Resource Centre at the time that was arranged. The Seniour Psychologist was interviewed in the office at the Student Counselling and Development Centre. Both interviews were recorded.

\subsection{INSTRUMENTS}

I he data was collected using structured questionnaires, and the intenviews as research instruments.

\subsubsection{Questionnaire}

A questionnaire consisted of written questions rclated to the topic of the study. Some of the questions were based on facts, past and present experiences, feelings and attitudes. A questionnaire was administered to the first year students from previously disadvantaged schools. The questionnaire (attached: see appendix 2) that was administered consisted of both, the quantitative and qualitative aspects of the proposed study and was divided into four sections. This questionnaire was designed specifically for this study. The questionnaire was designed by the researcher as the means to derive the kind of data that would appropriately answer the research questions.

A survey questionnaire was administered to the following subjects or respondents:

DIT (Durban Instirute of Technology) first year students from previously disadvantaged high schools 


\subsubsection{Components of the Questionnaire:}

The questionnaire consisted of close-ended and open-ended items and included the following: (Refer to Appendix 2)

\section{- Title Page}

A short statement clarifying the nature of the study was provided.

\section{- Section 1: Biographical Details}

These questions were designed to gather demographic data concerning age, gender, population, marital status, and mother tongue, from respondents.

\section{- Section 2: Familial Factors}

This section targeted family profiles. Information regarding the age, education, carcer and income brackets of the respondent's family/guardian was included in this section. This section also contained questions asking whether parents had an influence on the subjects' career choices, the respondents were required to give yes or no type responses, by putting a cross at an appropriate box where options were between yes, and or no.

\section{- Section 3: Educational Factors}

Items regarding respondents' matric subjects, matric points, importance of information types with regards to carcer decision-making, career guidance availability at their previous high schools, and career counseling influence by current institution were included in this section. Each question in this section provided respondents with possible responses, from which respondents had to choose from: For example, question 4.5 consist of 31 jkert-ype siale constricted to assess the level of importance of the different information influences on carreer decision-making of the subjects. The response altermatives ranged from not so important (scored 3), to Very important (scored 1). It also provided for open responses where respondents may have responses that differ from those provided.

\section{- Section 4: Individual and Psychosocial Factors}

The fourth section aimed at gathering information regarding individual, social, and socioenvironmental factors from subjects. Both close-ended and open-ended questions were used to obtain information, where close-ended questions provided possible responses to students and open-ended questions catered for elaborative and additional comments from the students. 
study were accordingly informed of the freedom to participate or not to participate, they were made aware of the purpose of the study and consequences of participation. The respondents were also informed that all information will be confidential and that anonymity would be respected. All information pertaining to the participants was to remain the property of the researcher and was not to be used for any other purpose except for the execution of this study.

\subsection{FACE VALIDITY OF INSTRUMENT}

The clarity, completeness, difficulty, sequencing, and value of each question, were, analyzed by three lecturers, who ate registered psychologists, and, therefore regarded as experts in career psychology. Feedback was used to modify the questions.

\subsection{STATISTICAL ANALYSIS}

This study investigated the factors that impact on career choices of first year technikon students from previously disadvantaged schools. The responses of the total sample were integrated and analysed for each section of the questionnaire. Descriptive statistics (frequencies and percentages), which are used to describe the variables of interest, were used in this study, for each question. Frequency refers to the number of rimes various subcategories of a certain phenomenon occur, from which the percentage of the occurrence of the subcategories can be easily calculated (Sekeran, 1992, p.259). A frequency indicates the number of subjects who receive each possible score on a variable (Cozby, 1981, p.64). A percent reports the number of units as a proportion of 100 (O'Sullivan \& Rassel, 1993, p.330). Allen (1990, p.330) defines percentage as rate or proportion percent. The computer programme Statistical Package for Social Sciences (SPSS) was used to analyse the data.

This study also examined relationships among variables, and therefore, aspects of correlational research were included. Comparison - Descriptive statistics (gender) were also used in this study, to establish if any relationship exists in terms of gender, for each question. Correlational research, according to Cohen and Manion (1980), is mainly concerned with achieving a fuller understanding of phenomena and behavioural patterns through the study of relationships between variables. In this study, correlational research was used to establish if a relationship between male and female responses exists of not, or, to establish if some pattern exist in responses with regards to gender. This type of research is particularly useful in investigating 
educational and social science problems, because it allows for the measurement of a number of variables and their relationships simultaneously.

\subsection{CONCLUSION}

This chapter provides a detailed explanation of the entire process involved in conducting this research from its conception. This included the research approach, data collection, and data analysis. A detailed gathening process had to be used because this study is on an under researched area in South A frica. 


\section{H A P T E R 5}

\section{DATA PRESENTATION AND ANALYSIS FOR DATA FINDINGS}

\subsection{ORIENTATION TO CHAPTER FIVE}

The previous chapter provided a detailed explanation of the processes involved in the research methodology. These included the research approach, data collection and data analysis.

This chapter aims to present the results of the study and data analysis. This chapter will present the data in accordance with the purpose and critical questions that underpin this study. The purpose of this study is to identify the factors impacting on career choices of first year technikon students from previously disadvantaged high schools.

The critical questions that provided the framework to guide the research and to achieve the purpose of the study were:

1. What are the social, educational and personal factors that influence the career choices of technikon students from previously disadvantagcd high schools?

2. Do the respondents consider they had effective guidance programme in theit previous high schools?

3. What role does the student counseling and development center in their current institutions play, in aiding the first year students (from previously disadvantaged high schools), regarding career choice difficulties.

The chapter has the following two sections:

SECTION 1: Analysis of Findings

SECTION 2: Presentation of Quantitative Data

SECTION 3: Presentation of Qualitative Data 


\section{SECTION 1: ANALYSIS OF FINDINGS}

The Statistical Package for the Social Sciences (SPSS) computer programme was used to interpret the data. Both descriptive and comparison-descriptive statistics were employed in this study. All the frequencies calculated are reported as valid percentages. All findings are reported in the $95 \%$ level of confidence $(p<.05)$. Percentages in tables are rounded off to whole numbers in the discussion of results. 'To facilitate actual data analysis, an analysis of certain items of information obtained from the questionnaire responses was necessary. The openended section of the questionnaire was analysed qualitarively.

\subsection{SECTION 2: QUANTITATIVE DATA PRESENTATION}

The research findings from this study are presented in the form of tables and descriptive statements. The information gathered from the questionnaires (with the exception of the open-ended questions) is described in this section. The results are reported under the following headings:

5.2.1 Valid percentages for the total sample

5.2.2 Analysis of familial factors influencing career choiccs

5.2.3 Analysis of educational factors influencing career choices

\subsubsection{Description of Sample}

The following tables describe the sample.

Table 5.1 Profile of respondents according to age

\begin{tabular}{|l|r|r|r|}
\hline & & & \\
Respondents age group & Frequency & Valid Percent & Cumulative Percent \\
\hline Under 18 & 4 & 5.0 & 5.0 \\
18 years & 11 & 13.8 & 18.8 \\
19 years & 20 & 25.0 & 43.8 \\
20 years & 15 & 18.8 & 62.5 \\
Above 20 years & 30 & 37.5 & 100.0 \\
Total & 80 & 100.0 & \\
& & & \\
\hline
\end{tabular}


Table 5.2 Respondents age group by gender

1.1 : Respondent age group. 1.2 Respondent Gender Crosstabulation

\begin{tabular}{|c|c|c|c|c|c|}
\hline \multicolumn{3}{|c|}{ Respondents age group } & \multicolumn{2}{|c|}{$\begin{array}{c}1.2 \text { Respondent } \\
\text { Gender }\end{array}$} & \multirow[b]{2}{*}{ Total } \\
\hline & & & Male & Female & \\
\hline \multirow[t]{5}{*}{$\begin{array}{l}1.1 \text { : Respondent } \\
\text { age group. }\end{array}$} & Under 18 & $\begin{array}{l}\text { Count } \\
\% \text { of Total }\end{array}$ & $\begin{array}{r}1 \\
1.3 \% \\
\end{array}$ & $\begin{array}{r}3 \\
3.8 \% \\
\end{array}$ & $\begin{array}{r}4 \\
5.0 \% \\
\end{array}$ \\
\hline & 18 years & $\begin{array}{l}\text { Count } \\
\% \text { of Total }\end{array}$ & $\begin{array}{r}5 \\
6.3 \% \\
\end{array}$ & $\begin{array}{r}6 \\
7.5 \% \\
\end{array}$ & $\begin{array}{r}11 \\
13.8 \% \\
\end{array}$ \\
\hline & 19 years & $\begin{array}{l}\text { Count } \\
\% \text { of Total }\end{array}$ & $\begin{array}{r}8 \\
10.0 \% \\
\end{array}$ & $\begin{array}{r}12 \\
15.0 \% \\
\end{array}$ & $\begin{array}{r}20 \\
25.0 \% \\
\end{array}$ \\
\hline & 20 years & $\begin{array}{l}\text { Count } \\
\% \text { of Total }\end{array}$ & $\begin{array}{r}8 \\
10.0 \% \\
\end{array}$ & $\begin{array}{r}7 \\
8.8 \% \\
\end{array}$ & $\begin{array}{r}15 \\
18.8 \% \\
\end{array}$ \\
\hline & Above 20 years & $\begin{array}{l}\text { Count } \\
\% \text { of Total }\end{array}$ & $\begin{array}{r}18 \\
22.5 \% \\
\end{array}$ & $\begin{array}{r}12 \\
15.0 \% \\
\end{array}$ & $\begin{array}{r}30 \\
37.5 \% \\
\end{array}$ \\
\hline \multicolumn{2}{|l|}{ Total } & $\begin{array}{l}\text { Count } \\
\% \text { of Total }\end{array}$ & $\begin{array}{r}40 \\
50.0 \% \\
\end{array}$ & $\begin{array}{r}40 \\
50.0 \% \\
\end{array}$ & $\begin{array}{r}80 \\
100.0 \%\end{array}$ \\
\hline
\end{tabular}

Tables 5.1 and 5.2 reflect that $38 \%$ (23\% males and 15\% females) of the respondents fell in the above 20 years age group, while 25\% (15\% females and 10\% males) were 19 years old, $19 \%$ (10\% males and $9 \%$ females) were 20 years old, and $19 \%$ (11\% females and $8 \%$ males) were 18 years old or younger. 
Table 5.3 Frequency distribution of all carecrs listed by total sample

\begin{tabular}{|c|c|c|c|}
\hline Respondents chosen careers & $\begin{array}{c}\text { Frequenc } \\
y\end{array}$ & Valid Percent & $\begin{array}{c}\text { Cumulative } \\
\text { Percent }\end{array}$ \\
\hline Accounting & 21 & 26.3 & 26.3 \\
\hline Art & 1 & 1.3 & 27.5 \\
\hline Biomedical Technology & 1 & 1.3 & 28.8 \\
\hline Business Management & 1 & 1.3 & 30.0 \\
\hline civil engineering & 8 & 10.0 & 40.0 \\
\hline Civil engineering & 1 & 1.3 & 41.3 \\
\hline Computer Programming & 1 & 1.3 & 42.5 \\
\hline Eco-Tourism Management & 3 & 3.8 & 46.3 \\
\hline education & 8 & 10.0 & 56.3 \\
\hline electrical engineering & 4 & 5.0 & 61.3 \\
\hline Engineering & 1 & 1.3 & 62.5 \\
\hline Information Technology & 4 & 5.0 & 67.5 \\
\hline Management & 8 & 10.0 & 77.5 \\
\hline Marketing & 1 & 1.3 & 78.8 \\
\hline $\begin{array}{l}\text { Office Management and } \\
\text { Technology }\end{array}$ & 5 & 6.3 & 85.0 \\
\hline Production Management & 1 & 1.3 & 86.3 \\
\hline Public Management & 3 & 3.8 & 90.0 \\
\hline Public Relations & 2 & 2.5 & 92.5 \\
\hline Surveying & 1 & 1.3 & 93.8 \\
\hline Tourism & 5 & 6.3 & 100.0 \\
\hline Total & 80 & 100.0 & \\
\hline
\end{tabular}

Table 5.3 indicates that $26 \%$ of the respondents indicated that they were in the Accounting field, $21 \%$ indicated they were in the Management and related fields, $20 \%$ indicated they were in the Engineering field, $10 \%$ indicated were in the Toursm field, while another $10 \%$ indicated were in the Education field, $8 \%$ in the Technology and related field, and a further $5 \%$ that included People Relations (3\%), Art (1\%), and Marketing (1\%) fields.

Table 5.4 Profile of sample according to gender

\begin{tabular}{|l|r|r|r|}
\hline & & & \\
\hline Gender & Frequency & Valid Percent & Cumulative Percent \\
\hline Male & 40 & 50.0 & 50.0 \\
Tomale & 40 & 50.0 & 100.0 \\
\hline
\end{tabular}

From Table 5.4 it is noted that $50 \%$ of the respondents were female and $50 \%$ were male. 
Table 5.5 Profile of sample according to population groups

\begin{tabular}{|l|r|r|r|}
\hline & & & Cumulative Percent \\
\hline Population Groups & Frequency & Valid Percent & Cur.5 \\
Coloured & 70 & 87.5 & 93.8 \\
Indian & 5 & 6.3 & 98.8 \\
Other & 4 & 5.0 & 100.0 \\
Total & 1 & 1.3 & \\
\hline
\end{tabular}

Table 5.5 indicates that $88 \%$ ( $45 \%$ females and $43 \%$ males) of the sample was from the African population group, and 6\% (4\% males and 3\% females) from the Coloured population group, and $5 \%$ ( $4 \%$ males and $1 \%$ females) from the Indian population group. The higher number of African students in the sample is due to the fact that they were the targeted group since they mostly attended the previously disadvantaged high schools, especially those in townships and nural areas.

Table 5.6 Respondents mother tongue by gender

1.5 : Mother Tongue * 1.2 Respondent Gender Crosstabulation

\begin{tabular}{|c|c|c|c|c|c|}
\hline \multicolumn{3}{|c|}{ Mother Tongue } & \multicolumn{2}{|c|}{$\begin{array}{c}\text { 1.2 Respondent } \\
\text { Gender }\end{array}$} & \multirow[b]{2}{*}{ Total } \\
\hline & & & Male & Female & \\
\hline \multirow{18}{*}{$\begin{array}{l}1.5: \\
\text { Mother } \\
\text { Tongue }\end{array}$} & English & Count & 4 & 1 & 5 \\
\hline & & $\%$ of Total & $5.0 \%$ & $1.3 \%$ & $6.3 \%$ \\
\hline & Afrikaans & Count & 0 & 3 & 3 \\
\hline & & $\%$ of Total & $.0 \%$ & $3.8 \%$ & $3.8 \%$ \\
\hline & Zulu & Count & 28 & 24 & 52 \\
\hline & & $\%$ of Total & $35.0 \%$ & $30.0 \%$ & $65.0 \%$ \\
\hline & Xhosa & Count & 4 & 9 & 13 \\
\hline & & $\%$ of Total & $5.0 \%$ & $11.3 \%$ & $16.3 \%$ \\
\hline & Sotho & Count & 1 & 1 & 2 \\
\hline & & $\%$ of Total & $1.3 \%$ & $1.3 \%$ & $2.5 \%$ \\
\hline & Venda & Count & 0 & 1 & 1 \\
\hline & & $\%$ of Total & $.0 \%$ & $1.3 \%$ & $1.3 \%$ \\
\hline & Tswana & Count & 1 & 0 & 1 \\
\hline & & $\%$ of Total & $1.3 \%$ & $.0 \%$ & $1.3 \%$ \\
\hline & Shangan & Count & 1 & 0 & 1 \\
\hline & & $\%$ of Total & $1.3 \%$ & $.0 \%$ & $1.3 \%$ \\
\hline & Ndebele & Count & 1 & 1 & 2 \\
\hline & & $\%$ of Total & $1.3 \%$ & $1.3 \%$ & $2.5 \%$ \\
\hline \multirow[t]{2}{*}{ Total } & & Count & 40 & 40 & 80 \\
\hline & & $\%$ of Total & $50.0 \%$ & $50.0 \%$ & $100.0 \%$ \\
\hline
\end{tabular}


Table 5.7 Profile of sample according to mother tongue

\begin{tabular}{|l|r|r|r|}
\hline & & & Cumulative Percent \\
\hline Mother Tongue & Frequency & Valid Percent & 6.3 \\
\hline English & 5 & 6.3 & 10.0 \\
Zurikaans & 3 & 3.8 & 75.0 \\
Xulu & 52 & 65.0 & 91.3 \\
Sothosa & 13 & 16.3 & 93.8 \\
Venda & 2 & 2.5 & 95.0 \\
Tswana & 1 & 1.3 & 96.3 \\
Shangan & 1 & 1.3 & 97.5 \\
Ndebele & 1 & 1.3 & 100.0 \\
Total & 2 & 2.5 & \\
\hline
\end{tabular}

Table 5.6 and 5.7 reflected that $65 \%$ (35\% males and 30\% females) of the sample indicated that isiZulu was their mother tongue, while $16 \%$ (11\% females and $5 \%$ males) indicated that isiXhosa was their mother tongue, $6 \%$ (5\% males and 1\% females) were English, $4 \%$ (all females) were Afrikaans, $3 \%$ for both the seSotho and Ndebele, and 1\% for Venda, Tswana, and Shangaan.

\subsubsection{Familial Factors}

The tables in this section reflect the family/ home conditions that were influential factors in the respondent's choice of career.

'Table 5.8 Respondents' living arrangements

\begin{tabular}{|l|r|r|r|}
\hline $\begin{array}{l}\text { Respondents' Living } \\
\text { Arrangements }\end{array}$ & Frequency & Valid Percent & Cumulative Percent \\
\hline Both parents & 26 & 32.5 & 32.5 \\
Mother & 22 & 27.5 & 60.0 \\
Father & 7 & 8.8 & 68.8 \\
Guardian & 18 & 22.5 & 91.3 \\
Others & 7 & 8.8 & 100.0 \\
Total & 80 & 100.0 & \\
\hline
\end{tabular}

Table 5.8 reflects that about 33\% (18\% males and 15\% females) of the respondents live with both parents. Thirty-seven percent came from single-parent homes, where $28 \%(20 \%$ females and $8 \%$ males) live with mothers and $9 \%$ (6\% males and $3 \%$ females) live with fathers. $23 \%$ (14\% males and $9 \%$ females) live with guardians. 
Table 5.9 Influence of who respondents live with on career choices

\begin{tabular}{|c|r|r|r|}
\hline & & & Cumulative Percent \\
\hline Responses & Frequency & Valid Percent & C1.3 \\
\hline Yes & 33 & 41.3 & 100.0 \\
No & 47 & 58.8 & \\
Total & 80 & 100.0 & \\
\hline
\end{tabular}

Table 5.9 shows us $41 \%$ (24\% males and 18\% females) indicated that "yes" who they live with influenced their choice of career, while 59\% (33\% females and $26 \%$ males) indicated "no".

Table 5.10 Approximate Income Level of family

\begin{tabular}{|c|r|r|r|}
\hline Family Income Levels & Frequency & Valid Percent & Cumulative Percent \\
\hline Missing & 3 & 3.8 & 3.8 \\
Below R 1000 & 17 & 21.3 & 25.0 \\
R $1000-R 3000$ & 14 & 17.5 & 42.5 \\
R 3000-R 5000 & 19 & 23.8 & 66.3 \\
R 5000-7000 & 16 & 20.0 & 86.3 \\
Above 7000 & 11 & 13.8 & 100.0 \\
Total & 80 & 100.0 & \\
\hline
\end{tabular}

Table 5.10 tells us that $39 \%$ of the respondents come from the lower-income family group (21\% earn below R 1000, and 18\% eam between R 1000 and R 3000), 33\% come from the upper-income family group (20\% earn between R 5000 and R 7000 , and $13 \%$ earn above R 7000 ), and $23 \%$ come from the middle-income family group (with $23 \%$ eaming between $\mathrm{R}$ 3000 and R 500()). The classification of income groups was constructed for the purpose of this study only and it was agreed on between the respondents and the researcher during the piloring of the questionnaire.

Table 5.11 Influence of respondents' family incomes on career choices

\begin{tabular}{|c|r|r|r|}
\hline & & & \\
Responses & Frequency & Valid Percent & Cumulative Percent \\
\hline Missing & 2 & 2.5 & 2.5 \\
Yes & 43 & 53.8 & 56.3 \\
No & 35 & 43.8 & 100.0 \\
Total & 80 & 100.0 & \\
\hline
\end{tabular}


According to 'Table 5.11: 54\% indicated that "yes" the level of their families income influenced their career choices, while $44 \%$ of the respondents indicated that " $n \bullet$ " their families level of income did not influence their career choices. Two percent did not respond.

Table 5.12 Family members responsible for payment for respondents' education

\begin{tabular}{|c|r|r|r|}
\hline $\begin{array}{c}\text { Family Members Responsible for } \\
\text { Respondents' education payment }\end{array}$ & Frequency & Valid Percent & \multicolumn{2}{c|}{$\begin{array}{c}\text { Cumulative } \\
\text { Percent }\end{array}$} \\
\hline Both parents & 13 & 16.3 & 16.3 \\
Mother & 25 & 31.3 & 47.5 \\
Father & 15 & 18.8 & 66.3 \\
Guardian & 6 & 7.5 & 73.8 \\
Other & 21 & 26.3 & 100.0 \\
Total & 80 & 100.0 & \\
\hline
\end{tabular}

Table 5.12 points out that a significant $31 \%(21 \%$ females and $10 \%$ males: a significant difference in gender) of the respondents indicated their that their mothers paid for studies, while $26 \%$ (16\% males and $10 \%$ females) indicated that their studies were funded by private and corporate bursaries or the Tertiary Education fund, 19\% (11\% males and $8 \%$ females) were funded by their fathers. $16 \%$ ( $(9 \%$ males and $7 \%$ females) indicated that both parents were paying for their studies, and $8 \%$ (4\% males and $4 \%$ females) indicated that their guardians were paying for their studies.

Table 5.13 Influence of who paid for respondents' education on career choices

\begin{tabular}{|c|r|r|r|}
\hline & & & Cumulative Percent \\
\hline Responses & Frequency & Valid Percent & Curs \\
Missing & 1 & 1.3 & 43.8 \\
Nos & 34 & 42.5 & 100.0 \\
Total & 45 & 56.3 & \\
\hline
\end{tabular}

Table 5.13 shows us that $43 \%$ ( $24 \%$ males and $19 \%$ females) of the respondents indicated that "yes", who pays for their studies, influenced their career choice; and 56\% (30\% females and $26 \%$ males) of the respondents responded with a "no". 
Table 5.14 Respondents fathers education levels

\begin{tabular}{|c|r|r|r|}
\hline Fathers level of education & Frequency & Valid Percent & Cumulative Percent \\
\hline Std 10 \& above & 32 & 40.0 & 40.0 \\
Std 10 & 9 & 11.3 & 51.3 \\
Std 6 & 6 & 7.5 & 58.8 \\
Below Std 6 & 2 & 2.5 & 61.3 \\
NA & 31 & 38.8 & 100.0 \\
Total & 80 & 100.0 & \\
\hline
\end{tabular}

It is indicated by Table 5.14 that $40 \%$ (24\% males and $16 \%$ females) of the respondents indicated that their fathers had standard ten and above, 39\% (23\% females and $16 \%$ males) responded with non-applicable, while $11 \%$ ( $7 \%$ females and $4 \%$ males) indicated their fathers had standard ten, and 10\% (6\% males and $4 \%$ females) of the respondents indicated that their fathers had standard six and below.

Table 5.15 Respondents mothers education levels

\begin{tabular}{|l|r|r|r|}
\hline & & & \\
Mothers level of education & Frequency & Valid Percent & Cumulative Percent \\
\hline Std 10 \& above & 37 & 46.3 & 46.3 \\
Std 10 & 10 & 12.5 & 58.8 \\
Std 6 & 7 & 8.8 & 67.5 \\
Below Std 6 & 7 & 8.8 & 76.3 \\
NA & 19 & 23.8 & 100.0 \\
Total & 80 & 100.0 & \\
\hline
\end{tabular}

Tables 5.15 points out that $46 \%$ (25\% males and $21 \%$ females) of the respondents indicated that their mothers had standard ten and above, $24 \%$ (14\% males and $10 \%$ females) responded with non-applicable, while $18 \%$ (10\% females and $8 \%$ males $)$ of the respondents indicated that their mothers had standard six and below, and 13\% (9\% females and 4\% males) indicated that their mothers had standard ten.

Table 5.16 Respondents guardians' education levels

\begin{tabular}{|l|r|r|r|}
\hline & & & \\
Guardians level of education & Frequency & Valid Percent & Cumulative Percent \\
\hline Std 10 \& above & 10 & 12.5 & 12.5 \\
Std 6 & 2 & 2.5 & 15.0 \\
Below Std 6 & 6 & 7.5 & 22.5 \\
NA & 62 & 77.5 & 100.0 \\
Total & 80 & 100.0 & \\
\hline
\end{tabular}


Tables 5.16 point out that $78 \%$ (39\% males and 39\% females) of the respondents responded with non applicable. $13 \%$ ( $8 \%$ females and $5 \%$ males) of respondents indicated that their guardians had standard ten and above, and 10\% (6\% males and 4\% females) indicated their guardians had standard six and below.

'Table 5.17 Influence of parent/guardians' educational attainment on career choices

\begin{tabular}{|c|r|r|r|}
\hline & & & \\
Responses & Frequency & Valid Percent & Cumulative Percent \\
\hline Missing & 1 & 1.3 & 1.3 \\
Yes & 43 & 53.8 & 55.0 \\
No & 36 & 45.0 & 100.0 \\
Total & 80 & 100.0 & \\
\hline
\end{tabular}

When the respondents were asked if their parents/guardians level of education influenced their choice of career, $54 \%$ (33\% males and $21 \%$ females) of the participants responded with "yes" while $45 \%$ (27\% females and 18\% males) indicated "no".

Table 5.18 Influence of parent/guardians on respondents' career choices

\begin{tabular}{|c|rrrr|}
\hline & & & \\
Responses & Frequency & Valid Percent & Cumulative Percent \\
\hline Yes & 39 & 48.8 & 48.8 \\
No & 41 & 51.3 & 100.0 \\
Total & 80 & 100.0 & \\
\hline
\end{tabular}

When the respondents were asked if their parents or guardians had any influence in their choice of career 51\% (24\% females and $27 \%$ males) responded with a "no" and $49 \%(26 \%$ males and $23 \%$ females) responded with "yes".

Table 5.19 Respondents views on who influence their career choices the most

\begin{tabular}{|c|r|r|r|}
\hline $\begin{array}{c}\text { Respondents views on who } \\
\text { influence their career choice most }\end{array}$ & Frequency & Valid Percent & Cumulative Percent \\
\hline Missing & 9 & 11.3 & 11.3 \\
Father & 14 & 17.5 & 28.8 \\
Mother & 42 & 52.5 & 81.3 \\
Guardian & 14 & 17.5 & 98.8 \\
F \&M & 1 & 1.3 & 100.0 \\
Total & 80 & 100.0 & \\
\hline
\end{tabular}


Table 5.20 Sources of most influence on career choices by gender

2.8 : Who influenced your career choice the most. * 1.2 Respondent Gender Crosstabulation

\begin{tabular}{|c|c|c|c|c|c|}
\hline \multirow{2}{*}{\multicolumn{3}{|c|}{$\begin{array}{l}\text { Sources of most influence on career choices } \\
\text { bv aender }\end{array}$}} & \multicolumn{2}{|c|}{$\begin{array}{c}\text { 1.2 Respondent } \\
\text { Gender }\end{array}$} & \multirow[b]{2}{*}{ Total } \\
\hline & & & Male & Female & \\
\hline \multirow{5}{*}{$\begin{array}{l}2.8: \text { Who influenced } \\
\text { your career choice } \\
\text { the most. }\end{array}$} & Missing & $\begin{array}{l}\text { Count } \\
\% \text { of Total }\end{array}$ & $\begin{array}{r}7 \\
8.8 \%\end{array}$ & $\begin{array}{r}2 \\
2.5 \%\end{array}$ & $\begin{array}{r}9 \\
11.3 \%\end{array}$ \\
\hline & Father & $\begin{array}{l}\text { Count } \\
\% \text { of Total }\end{array}$ & $\begin{array}{r}7 \\
8.8 \% \\
\end{array}$ & $\begin{array}{r}7 \\
8.8 \% \\
\end{array}$ & $\begin{array}{r}14 \\
17.5 \% \\
\end{array}$ \\
\hline & Mother & $\begin{array}{l}\text { Count } \\
\% \text { of Total }\end{array}$ & $\begin{array}{r}18 \\
22.5 \% \\
\end{array}$ & $\begin{array}{r}24 \\
30.0 \% \\
\end{array}$ & $\begin{array}{r}42 \\
52.5 \%\end{array}$ \\
\hline & Guardian & $\begin{array}{l}\text { Count } \\
\% \text { of Total }\end{array}$ & $\begin{array}{r}8 \\
10.0 \% \\
\end{array}$ & $\begin{array}{r}6 \\
7.5 \% \\
\end{array}$ & $\begin{array}{r}14 \\
17.5 \% \\
\end{array}$ \\
\hline & $F \& M$ & $\begin{array}{l}\text { Count } \\
\% \text { af Total }\end{array}$ & $\begin{array}{r}0 \\
.0 \% \\
\end{array}$ & $\begin{array}{r}1 \\
1.3 \% \\
\end{array}$ & $\begin{array}{r}1 \\
1.3 \% \\
\end{array}$ \\
\hline \multicolumn{2}{|l|}{ Total } & $\begin{array}{l}\text { Count } \\
\% \text { of Total }\end{array}$ & $\begin{array}{r}40 \\
50.0 \%\end{array}$ & $\begin{array}{r}40 \\
50.0 \%\end{array}$ & $\begin{array}{r}80 \\
100.0 \%\end{array}$ \\
\hline
\end{tabular}

When the respondents were asked, who had the most influence in their choice of career, $53 \%$ (30\% females and 23\% males) indicated their mothers had the most influence, while $18 \%(9 \%$ males and 9\% females) indicated it was their fathers and another 18\% (10\% males and $8 \%$ females) indicated it was their guardians. $11 \%$ ( $9 \%$ males and $2 \%$ females) did not respond while only $1 \%$ (all females) indicated that both mother and father had the most influence.

\subsubsection{Educational Factors}

The following tables reflect the educational factors that were influential in the respondent's choice of career.

Table 5.21 Influence of high school subjects on career choices

\begin{tabular}{|l|r|r|r|}
\hline & & & \\
Responses & Frequency & Valid Percent & Cumulative Percent \\
\hline Yes & 60 & 75.0 & 75.0 \\
No & 20 & 25.0 & 100.0 \\
Total & 80 & 100.0 & \\
\hline
\end{tabular}

When the respondents were asked if the subject chosen at high school influenced their choice of career, $75 \%$ (40\% males and 35\% females) responded with "yes", while $25 \%$ (15\% females and $10 \%$ males) responded with "no". 
Table 5.22 Effect of matric points on the course of study chosen at the technikon

\begin{tabular}{|c|rrrr|}
\hline & & & \\
Responses & Frequency & Valid Percent & Cumulative Percent \\
\hline Yes & 42 & 52.5 & 52.5 \\
No & 38 & 47.5 & 100.0 \\
Total & 80 & 100.0 & \\
\hline
\end{tabular}

When the respondents were asked if the number of matric points obtained determined which course they were to follow, $53 \%$ (29\% males and $24 \%$ females) responded with "yes", and $47 \%$ (21\% females and 26\% males) indicated "no".

Table 5.23 Availability of career guidance programme in previous high school of respondents

\begin{tabular}{|c|r|r|r|}
\hline & & & \\
Responses & Frequency & Valid Percent & Cumulative Percent \\
\hline Yes & 50 & 62.5 & 62.5 \\
No & 30 & 37.5 & 100.0 \\
Total & 80 & 100.0 & \\
\hline
\end{tabular}

Table 5.24 Availability of career guidance in previous high school of respondents by gender

3.3a: Did the school where you did your grade 12 have a career guidance programme. * 1.2 Respondent Gender Crosstabulation

\begin{tabular}{|c|c|c|c|c|c|}
\hline \multicolumn{3}{|c|}{$\begin{array}{l}\text { Respondents' responses on availability of } \\
\text { career guidance on their previous high school }\end{array}$} & \multicolumn{2}{|c|}{$\begin{array}{l}1.2 \text { Respondent } \\
\text { Gender }\end{array}$} & \multirow[b]{2}{*}{ Total } \\
\hline & & & Male & Female & \\
\hline \multirow{4}{*}{$\begin{array}{l}\text { 3.3a: Did the school } \\
\text { where you did your } \\
\text { grade } 12 \text { have a career } \\
\text { guidance programme. }\end{array}$} & Yes & Count & 25 & 25 & 50 \\
\hline & & $\%$ of Total & $31.3 \%$ & $31.3 \%$ & $62.5 \%$ \\
\hline & No & Count & 15 & 15 & 30 \\
\hline & & $\%$ of Total & $18.8 \%$ & $18.8 \%$ & $37.5 \%$ \\
\hline \multirow[t]{2}{*}{ Total } & & Count & 40 & 40 & 80 \\
\hline & & $\%$ of Total & $50.0 \%$ & $50.0 \%$ & $100.0 \%$ \\
\hline
\end{tabular}

When the respondents were asked if the last school they attended had a guidance programme, $62 \%$ (31\% males and 31\% females) indicated "yes" while $38 \%$ (19\% males and $19 \%$ females) responded with a "no". 
Table 5.25 Influence of previous high school career guidance pregramme on career choices

\begin{tabular}{|c|r|r|r|}
\hline Responses & Frequency & Valid Percent & \multicolumn{1}{c|}{ Cumulative Percent } \\
\hline Yes & 30 & 37.5 & 37.5 \\
No & 23 & 28.8 & 66.3 \\
NA & 27 & 33.8 & 100.0 \\
Total & 80 & 100.0 & \\
\hline
\end{tabular}

Table 5.26 School's career guidance programme influence by gender

3.3b : If yes, did it influence your choice of career. 1.2 Respondent Gender

Crosstabulation

\begin{tabular}{|c|c|c|c|c|c|}
\hline \multirow{2}{*}{\multicolumn{3}{|c|}{$\begin{array}{l}\text { Responses on whether the school } \\
\text { guidance programme hadan influence }\end{array}$}} & \multicolumn{2}{|c|}{$\begin{array}{l}1.2 \text { Respondent } \\
\text { Gender }\end{array}$} & \multirow[b]{2}{*}{ Total } \\
\hline & & & Male & Female & \\
\hline \multirow{6}{*}{$\begin{array}{l}3.3 \mathrm{~b}: \text { If yes, did it } \\
\text { influence your choice } \\
\text { of career. }\end{array}$} & Yes & Count & 14 & 16 & 30 \\
\hline & & $\%$ of Total & $17.5 \%$ & $20.0 \%$ & $37.5 \%$ \\
\hline & No & Count & 14 & 9 & 23 \\
\hline & & $\%$ of Total & $17.5 \%$ & $11.3 \%$ & $28.8 \%$ \\
\hline & NA & Count & 12 & 15 & 27 \\
\hline & & $\%$ of Total & $15.0 \%$ & $18.8 \%$ & $33.8 \%$ \\
\hline \multirow[t]{2}{*}{ Total } & & Count & 40 & 40 & 80 \\
\hline & & $\%$ of Total & $50.0 \%$ & $50.0 \%$ & $100.0 \%$ \\
\hline
\end{tabular}

When the respondents were asked if their school guidance programme influenced them, $37 \%$ (20\% females and 17\% males) indicated that "yes" it influenced them, and $29 \%$ (18\% males and $11 \%$ females) indicated "no".

Table 5.27 Rate of performance level of career programmes in the previously disadvantaged high schools

\begin{tabular}{|l|r|r|r|}
\hline $\begin{array}{c}\text { Respondents Rating of performance } \\
\text { level of programme in their previous } \\
\text { high schools }\end{array}$ & Frequency & Valid Percent & Cumulative Percent \\
\hline Very effective & 21 & 26.3 & 26.3 \\
Somewhat effective & 18 & 22.5 & 48.8 \\
Not effective & 4 & 5.0 & 53.8 \\
NA & 37 & 46.3 & 100.0 \\
Total & 80 & 100.0 & \\
\hline
\end{tabular}


'Table 5.28 Respondents' rating of previous high school guidance programme by gender

3.3c:If yes, where would you rate the programme in the following ratings. * 1.2 Respondent Gender Crosstabulation

\begin{tabular}{|c|c|c|c|c|c|}
\hline \multicolumn{3}{|c|}{$\begin{array}{l}\text { Respondents Rating of performance level of } \\
\text { proqramme in their previous hiqh schools }\end{array}$} & \multicolumn{2}{|c|}{$\begin{array}{l}1.2 \text { Respondent } \\
\text { Gender }\end{array}$} & \multirow[b]{2}{*}{ Total } \\
\hline \multirow{9}{*}{$\begin{array}{l}3.3 \text { cif yes, where would } \\
\text { you rate the programme } \\
\text { in the following ratings. }\end{array}$} & & & Male & Female & \\
\hline & Very effective & Count & 12 & 9 & 21 \\
\hline & & $\%$ of Total & $15.0 \%$ & $11.3 \%$ & $26.3 \%$ \\
\hline & Somewhat effective & Count & 7 & 11 & 18 \\
\hline & & $\%$ of Total & $8.8 \%$ & $13.8 \%$ & $22.5 \%$ \\
\hline & Not effective & Count & 2 & 2 & 4 \\
\hline & & $\%$ of Total & $2.5 \%$ & $2.5 \%$ & $5.0 \%$ \\
\hline & NA & Count & 19 & 18 & 37 \\
\hline & & $\%$ of Total & $23.8 \%$ & $22.5 \%$ & $46.3 \%$ \\
\hline \multirow[t]{2}{*}{ Total } & & Count & 40 & 40 & 80 \\
\hline & & $\%$ of Total & $50.0 \%$ & $50.0 \%$ & $100.0 \%$ \\
\hline
\end{tabular}

Tables 5.27 and 5.28 point out that $26 \%$ ( $15 \%$ males and $11 \%$ females) indicated that their school guidance progrmme was very effective, while 23\% ( $9 \%$ females and $14 \%$ males) indicated the programme was somewhat effective, and $5 \%$ (2.5\% males and $2.5 \%$ females) indicated the programme was not effective.

Table 5.29 Subjects' responses with regard to career counseling received from current institution

\begin{tabular}{|c|r|r|r|}
\hline & & & \\
Responses & Frequency & Valid Percent & Cumulative Percent \\
\hline Yes & 23 & 28.8 & 28.8 \\
No & 57 & 71.3 & 100.0 \\
Total & 80 & 100.0 & \\
\hline
\end{tabular}

Table 5.29 points out that $71 \%$ (36\% males and 35\% females) of the respondents responded with "no", and 29\% (15\% females and 14\% males) indicated "yes" they received carcer counseling from the current institution before enrolling with them.

Table 5.30 Influence of career counseling of current institution on career choices

\begin{tabular}{|c|r|r|r|}
\hline & & & Cumulative Percent \\
\hline Responses & Frequency & Valid Percent & 25.0 \\
Yes & 20 & 25.0 & 31.3 \\
No & 5 & 6.3 & 100.0 \\
NA & 55 & 68.8 & \\
Total & 80 & 100.0 & \\
\hline
\end{tabular}


Table 5.30 points out that $25 \%$ ( $14 \%$ males and $11 \%$ females) indicated "yes " the carcer counseling from the technikon influenced their decision, while $6 \%$ (5\% females and $1 \%$ males) indicated "no".

\subsubsection{Individual and Psycho-Social Factors}

From table 5.31 up to table 4.43, personal/ indiridual and psychosocial factors that influenced the respondents in their choice of career are reflected.

Table 5.31 Certainty of respondents about their chosen careers

\begin{tabular}{|l|r|r|r|}
\hline & & & \\
Respondents' level of certainty & Frequency & Valid Percent & Cumulative Percent \\
\hline Missing & 1 & 1.3 & 1.3 \\
Very certain & 34 & 42.5 & 43.8 \\
Certain & 34 & 42.5 & 86.3 \\
A little uncertain & 7 & 8.8 & 95.0 \\
Not at all certain & 4 & 5.0 & 100.0 \\
Total & 80 & 100.0 & \\
\hline
\end{tabular}

Tables 5.31 points out that $43 \%$ ( $23 \%$ females and $20 \%$ males) indicated that they were "very certain" about their chosen careers, while a further $43 \%$ ( $24 \%$ males and 19\% females) indicated were "certain", $9 \%$ (5\% females and 4\% males) responded as "a little uncertain", and $5 \%(2.5 \%$ males and $2.5 \%$ females $)$ indicated that they were "not at all certain" about their chosen careers.

Table 5.32 Gender influence on career choices

\begin{tabular}{|l|r|r|r|}
\hline & Frequency & Valid Percent & Curmulative Percent \\
\hline Missing & 1 & 1.3 & 1.3 \\
Yes & 18 & 22.5 & 23.8 \\
No & 61 & 76.3 & 100.0 \\
Total & 80 & 100.0 & \\
& & & \\
\hline
\end{tabular}

Tables 5.32 points out that When the respondents were asked if their gender influenced their choice of career, $76 \%$ (39\% females and 37\% males) responded with a "no", while $23 \%(13 \%$ males and $10 \%$ females) responded with a "yes". 
Table 5.33 Other factors indicated by respondents to have influenced theirr career choices

\begin{tabular}{|c|c|c|c|c|}
\hline \multicolumn{2}{|c|}{ Possible Influential Factors } & Frequency & per Response & Valid Percent \\
\hline 0 & Missing & & 1 & 1.3 \\
\hline 1 & $\begin{array}{l}\text { Finance ie low family } \\
\text { income }\end{array}$ & & 33 & 41.3 \\
\hline 2 & $\begin{array}{l}\text { Parent guardians } \\
\text { occupation }\end{array}$ & & 21 & 26.3 \\
\hline 3 & Teacher's influence & & 20 & 25.0 \\
\hline 4 & Influence of friends & & 16 & 20.0 \\
\hline 5 & Your matric results & & 33 & 41.3 \\
\hline 6 & Community's influence & & 13 & 16.3 \\
\hline 7 & $\begin{array}{l}\text { Your school subjects } \\
\text { and experience at school }\end{array}$ & & 28 & 35.0 \\
\hline 8 & $\begin{array}{l}\text { Your interests and } \\
\text { hobbies }\end{array}$ & & 25 & 31.3 \\
\hline 9 & Part-time job experience & & 13 & 16.3 \\
\hline 10 & $\begin{array}{l}\text { Research into the } \\
\text { occupation }\end{array}$ & & 22 & 27.5 \\
\hline 11 & Career pays well & & 30 & 37.5 \\
\hline 12 & $\begin{array}{l}\text { Counseling by current } \\
\text { institution }\end{array}$ & & 6 & 7.5 \\
\hline 13 & $\begin{array}{l}\text { Media: as in } \\
\text { radio,television,newspap } \\
\text { er or magazine }\end{array}$ & & 29 & 36.3 \\
\hline 14 & Other factors & & 2 & 2.3 \\
\hline
\end{tabular}

When the respondents were asked to indicate as many factors as possible from the given possible factors that influenced their career choices, the following emerged from Table 5.33: Fourty-one percent (41\%) indicated "funance" was an influential factor, a further $41 \%$ responded to "matric results", $38 \%$ indicated that the y were influenced by "careers that pay well", $36 \%$ indicated that they were influenced by "media", $35 \%$ pointed towards "school subjects" as influential factors, while $31 \%$ responded to "interests and hobbies", $28 \%$ indicated it was "research into the occupation", $26 \%$ indicated it was "parent/guardian's occupation", $25 \%$ pointed to the "teacher's influence", $20 \%$ responded to "influence of friends", $16 \%$ for "community's influence", a further $16 \%$ for "part-rime job experience" and $8 \%$ for "counseling by current institution". 
Table 5.34 The single most influential factor on respondents' choice of career

\begin{tabular}{|c|c|c|c|c|}
\hline $\begin{array}{l}\text { Mo } \\
\mathrm{Re}\end{array}$ & Respondents & Frequency & Valid Percent & \multirow{2}{*}{$\frac{\text { Cumulative Percent }}{6.3}$} \\
\hline 0 & Missing & 5 & 6.3 & \\
\hline 1 & Finance: eg, low family income & 11 & 13.8 & 20.0 \\
\hline 2 & Parent Guardians occupation & 3 & 3.8 & 23.8 \\
\hline 3 & Teacher's Influence & 5 & 6.3 & 30.0 \\
\hline 4 & Influence of friends & 4 & 5.0 & 35.0 \\
\hline 5 & Matric results & 7 & 8.8 & 43.8 \\
\hline 6 & Community's influence & 3 & 3.8 & 47.5 \\
\hline 7 & Shool: subjects \& experience & 8 & 10.0 & 57.5 \\
\hline 8 & Interest and hobbies & 8 & 10.0 & 67.5 \\
\hline 9 & Part-time job experience & 4 & 5.0 & 72.5 \\
\hline 10 & Research into the occupation & 11 & 13.8 & 86.3 \\
\hline 11 & Career pays well & 2 & 2.5 & 88.8 \\
\hline 12 & Media, as in radio, television etc. & 8 & 10.0 & 98.8 \\
\hline 13 & Counselling by current institution & 1 & 1.3 & 100.0 \\
\hline & Total & 80 & 100.0 & \\
\hline
\end{tabular}

When asked what was the single most influential factor, Table 5.34 shows us that $14 \%$ of the respondents indicated "finance", while another 14\% indicated it was "carecr pays well", $10 \%$ indicated "school subjects and experience at school", a further $10 \%$ indicated "interests and hobbies", and another $10 \%$ indicated media. $9 \%$ indicated that it was the matric points.

Table 5.35 Problems respondents associated with their career choices

\begin{tabular}{|l|r|r|}
\hline Possible Problematic Factors & Frequency & Valid Percent \\
\hline $0 \quad$ Missing & 9 & 11.3 \\
$1 \quad$ Enough information to make a decision & 16 & 20.0 \\
$2 \quad$ Many possibilities & 23 & 28.8 \\
3 Confusion as to what to do & 15 & 18.8 \\
4 Admission to various institutions & 10 & 12.5 \\
5 Pressure from friends & 11 & 13.8 \\
6 Your results were not good enough & 11 & 13.8 \\
7 Uncertainty about financial support & 15 & 18.8 \\
8 Other reasons & 2 & 2.5 \\
\hline
\end{tabular}

When the respondents were asked to indicate (from the given possible problematic factors) what were the contributing factors towards their difficulties in choosing their careers before they did, Table 5.35 indicates that $29 \%$ of the respondents indicated that they had many possibilities, while $20 \%$ indicated they did not have enough information, $19 \%$ pointed out that they were confused as to what to de, a further $19 \%$ indicated they were uncertain about 
financial support, while $14 \%$ indicated there was pressure from friends, a further $14 \%$ pointed out that their academic performance were not good enough, and $13 \%$ indicated that they had difficulties in deciding which instrution to go to as they were accepted at various institutions (decision making).

'Table 5.36 Respondents' rate of the importance of persenal information on career choices

\begin{tabular}{|l|r|r|r|}
\hline Rating by respondents & Frequency & Valid Percent & Cumulative Percent \\
\hline Missing & 4 & 5.0 & 5.0 \\
Very Important & 52 & 65.0 & 70.0 \\
Important & 16 & 20.0 & 90.0 \\
Not so Important & 8 & 10.0 & 100.0 \\
Total & 80 & 100.0 & \\
\hline
\end{tabular}

According to Table 5.36 when the respondents were asked to respond to a scale asking them how important is the information about themselves in career decision-making, $65 \%(34 \%$ females and $31 \%$ males $)$ of the respondents indicated it was very important, while $20 \%(10 \%$ males and $10 \%$ females $)$ indicated it was important, and $10 \%$ ( $6 \%$ males and $4 \%$ females $)$ indicated it was not so important.

Table 5.37 Respondents' rate of the importance of information about careers on their career choices

\begin{tabular}{|l|r|r|r|}
\hline & & & \\
Rating by respondents & Frequency & Valid Percent & Cumulative Percent \\
\hline Missing & 4 & 5.0 & 5.0 \\
Very Important & 64 & 80.0 & 85.0 \\
Important & 9 & 11.3 & 96.3 \\
Not so Important & 3 & 3.8 & 100.0 \\
Total & 80 & 100.0 & \\
\hline
\end{tabular}

According to Table 5.37 when the respondents were asked to respond to a scale asking them how important is the information about careers in career decision-making, $80 \% \quad(42.5 \%$ females and $37.5 \%$ males) of the respondents indicated it was very important, while $11 \%(6 \%$ males and 5\% females) indicated it was important, and 4\% (all male) indicated it was not so important. 
Table 5.38 Respondents' rate of the importance of information about employers on their career decision-making

\begin{tabular}{|l|r|r|r|}
\hline & & & \\
Rating by respondents & Frequency & Valid Percent & Cumulative Percent \\
\hline Missing & 5 & 6.3 & 6.3 \\
Very Important & 34 & 42.5 & 48.8 \\
Important & 32 & 40.0 & 88.8 \\
Not so Important & 9 & 11.3 & 100.0 \\
Total & 80 & 100.0 & \\
\hline
\end{tabular}

According to Table 5.38 when the respondents were asked to respond to a scale asking them how important is the information about employers in carecr decision-making, $43 \%$ (24\% males and $19 \%$ females) of the respondents indicated it was very important, while $40 \%$ (25\% females and $15 \%$ males $)$ indicated it was important, and $11 \%$ (9\% males and $2 \%$ females) indicated it was not so important.

Table 5.39 Respondents' indication of the importance of information on admission criteria requirements on their career decision-making

\begin{tabular}{|l|r|r|r|}
\hline & & & \\
Rating by respondents & Frequency & Valid Percent & Cumulative Percent \\
\hline Missing & 4 & 5.0 & 5.0 \\
Very important & 48 & 60.0 & 65.0 \\
Important & 23 & 28.8 & 93.8 \\
Not so Important & 5 & 6.3 & 100.0 \\
Total & 80 & 100.0 & \\
\hline
\end{tabular}

According to Table 5.39 when the respondents were asked to respond to a scale asking them how important is the information about admission criteria in career decision-making, $60 \%$ (30\% males and $30 \%$ females) of the respondents indicated it was very important, while $29 \%$ (16\% males and 13\% females) indicated it was important, and $6 \%(1 \%$ females and $5 \%$ males) indicated it was not so important. 
Table 5.40 Respondents' indication of the importance of information on job opportunities on their career decision-making.

\begin{tabular}{|l|r|r|r|}
\hline & & & \\
Rating by respondents & Frequency & Valid Percent & Cumulative Percent \\
\hline Missing & 4 & 5.0 & 5.0 \\
Very Important & 65 & 81.3 & 86.3 \\
Important & 9 & 11.3 & 97.5 \\
Not so Important & 2 & 2.5 & 100.0 \\
Total & 80 & 100.0 & \\
\hline
\end{tabular}

Table 5.40 shows us that when the respondents were asked to respond to a scale asking them how important is the information about job opportunities in carcer decision-making, 81\% ( $41 \%$ males and $40 \%$ females) of the respondents indicated it was very important, while $11 \%$ $(6 \%$ males and $5 \%$ females) indicated it was important, and 3\% (all females) indicated it was not so important.

Table 5.41 Importance of information about financial sustainability on career choices

\begin{tabular}{|l|r|r|r|}
\hline & & & \\
Rating by respondents & Frequency & Valid Percent & Cumulative Percent \\
\hline Missing & 4 & 5.0 & 5.0 \\
Very Important & 60 & 75.0 & 80.0 \\
Important & 15 & 18.8 & 98.8 \\
Not so Important & 1 & 1.3 & 100.0 \\
Total & 80 & 100.0 & \\
\hline
\end{tabular}

Table 5.41 revealed that when the respondents were asked to respond to a scale asking them how important is the information about finance in career decision-making, 75\% (3)\% females and $36 \%$ males) of the respondents indicated it was very important, while $19 \%$ (11\% males and $8 \%$ females) indicated it was important, and $1 \%$ (all females) indicated it was not so important.

Table 5.42 Respondents indication on whether the careers they are currently pursuing are the ones that they originally wanted to follow.

\begin{tabular}{|l|r|r|r|}
\hline & & & \\
Responses & Frequency & Valid Percent & Cumulative Percent \\
\hline Missing & 3 & 3.8 & 3.8 \\
Yes & 41 & 51.3 & 55.0 \\
No & 36 & 45.0 & 100.0 \\
Total & 80 & 100.0 & \\
\hline
\end{tabular}


Table 5.42 revealed that when the respondents were asked if their current careers were the ones they oniginally wanted; $51 \%$ (26\% males and 25\% females) responded with "yes", whilc $45 \%$ (25\% females and $20 \%$ males) responded with "no".

Table 5.43 Respondents indication on whether the careets they are currently pursuing were chosen by chance

\begin{tabular}{|c|r|r|r|}
\hline & & & \\
Responses & Frequency & Valid Percent & Cumulative Percent \\
\hline Missing & 12 & 15.0 & 15.0 \\
Yes & 16 & 20.0 & 35.0 \\
No & 52 & 65.0 & 100.0 \\
Total & 80 & 100.0 & \\
\hline
\end{tabular}

Table 5.43 indicates that when the respondents were asked if they chose their careers by chance; $65 \%$ (34\% females and 31\% males) responded with "no", while $20 \%$ (11\% females and $9 \%$ males) responded with "yes".

\subsection{SECTION 3: QUALITATIVE DATA PRESENTATION}

The researcher also used a qualitative data analyses technique in this study, for the interviews and the open-ended questions in the questionnaire. In the analysis of qualitative data the researcher looked for recurrent themes and concepts. The researcher had to record information accurately, divide from important details, and draw appropnate conclusions from information.

\subsubsection{Analysis of open-ended questions by students (sections in questionnaire)}

Approximately $35 \%$ of the respondents answered the open-ended sections of the questionnaire. A brief analysis of comments, which are regarded as pertinent to this study follows. The majority of responses had elements of commonality and hence it was considered prudent to group them into themes. The following themes emerged as the most prominent:

The need for financial support was reiterated by the respondents

The need for effective school guidance progtammes from the early school years was echoed by many respondents

A strong need for resource centers in townships and rural settings was aired by many respondents

A need for modern technology in township and rural schools was also cited 


\subsubsection{Analysis of interview questions by the Psychologist and Careers Librarian}

The majority of the responses from both interviewees also had some common elements. The themes that emerged as the most prominent were as follows:

\section{a) The most common presenting problem by students are,}

- Poor English (both marks and comprehension)- making selection into tertiary institution, in which the medium of instruction is English, difficult

- Not being able to articulate clear career options

- Lack of knowledge about different careers and career options

- Difficulty in integrating personal information and occupational information, in order to make a carecr decision

- Applying for courses very late

- Financial difficulties

b) Factors contributing to the above problems were indicated as,

- Lack of adequate career guidance in high schools, particularly the previously disadvantaged high schools

- Employment opportunitics, where students may select a career that they are otherwise not suited to

- Family's opinions

The next chapter discusses the results, proposes recommendations, and presents conclusion, as well as discusses the limitations to the study. 
C H A P T E R 6

\section{DISDCUSSION OF RESULTS, CONCLUSION, RECOMMENDATIONS, AND LIMITATIONS}

\section{DISCUSSION OF RESULTS}

\subsection{ORIENTATION TO CHAPTER SIX}

The primary aim of this study was to identify factors that impact on career choices of first year technikon students from previously disadvantaged high schools.

The critical questions that provided the framework to guide the research and to achicve the purpose of the study were:

1. What are the social, educational and personal factors that influence the career choices of technikon students from previously disadvantaged high schools?

2. Do the respondents consider they had effective guidance programme in their previous high schools?

3. What role does the student counseling and development center in their current institutions play, in aiding the first year students (from previously disadvantaged high schools), regarding career choice difficulties.

\subsection{SUMMARY OF FINDINGS}

This section presents the summary of findings in accordance with what the data analysis in chapter five revealed.

Different factors were identified as having influenced the career choices of the participants under study, the most dominant being finance, parent/guardians education level, mothers, subject choice, matric points/ results, poor English, and, media. It was further revealed by the sample in this research that factors such as insufficient information, many possibilities to choose from, confusion as to what to do, admission at various institutions, pressure from friends, results not being good enough, and uncertainty about sponsor for studies /or lack of 
financial support, attributed to be some of the major obstacles or batriets that these students are faced with when making a career choice. Lack of or poor guidance and counselling programme at the previously disadvantaged high schools were also found to be among the factors impacting on career choice of the subjects under this study.

\subsection{DISCUSSION OF RESULTS:}

\subsubsection{Total Sample}

Eighty students were profiled -in Tables 5.1- 5.7- according to various descriptors, incorporating biographical details and careers/ courses chosen by respondents during this study. Noteworthy aspects will be elucidated in this discussion.

Tables $5.1-5.2$ shows that the majority of the respondents fell in the above 20 years age group, with more males falling in this age group than females. This age group, according to Gottfredson (1981), is the age of compromise, a stage where aspirations are modified to adapt to reality conswaints.

The respondents were equally distributed in terms of gender. There were 40 females and 40 males who were subjects of this study. In Table 5.4 it is noted that $50 \%$ of the respondents were female and $50 \%$ were male.

Table 5.5 indicates that the majority of the sample population is from the African population group. The higher number of African students in the sample is due to the fact that they were the targeted group since they mostly attended the previously disadvantaged high schools, especially those in townships and rural areas.

Table 5.6 and 5.7 shows that the majority (35\% males and $30 \%$ females) of the sample population are Zulu speaking, while the Xhosa speaking form the second largest language group (11\% females and 5\% males) in the sample. Only $6 \%$ (5\% males and $1 \%$ fermales) are English speaking, 4\% (all females) are Afrikaans speaking, 3\% for both the seSøtho and Ndebele speaking, and $1 \%$ shared by Venda, Tswana, and Shangaan speaking language groups. 


\subsubsection{Social, educational and personal factors}

The two most influential factors as indicated by this study's sample were finance, and careers that pay well:

\section{$\therefore$ Finance}

When the respondents were asked what was the single most influential factor, (Table 5.34) the majority of the respondents indicated it was "tinance". Table 5.10 shows that, the majority (39\%) of respondents come from the lower-income family growp (21\% earn below R 1000 , and $18 \%$ earn between R 1000 and R 3000). The classification of income groups (in terms of lower, middle and upper income group classifications) was constructed for the purpose of this study only and it was agreed on between the respondents and the researcher during the piloting and administration of the questionnaire. Fifty-three percent of the respondents from the total sample said that the family income level influenced their career choice. They elucidated by pointing out that low family income has led them to choose cheaper and shorter courses and some even having to rely entirely on the financial assistance provided by the tertiary institution fund. 'This is in line with Gottfredson's developmental model, where it is mentioned that people also compromise with anticipated barriers. In this study, the respondents showed that their financial barriers have caused them to compromise potential career fields (careers that appeared to be expensive to them) for those career fields that are cheaper and more affordable for their families. Some respondents also added that they had no idea that there was financial assistance for the students who are financially disadvantaged until they were enrolled at the institution. Some indicated that they had to find just enough money for registration, and thereafter, rely entirely on the financial assistance provided by their current institution. Some respondents also indicated that due to insufficient family income, some of their siblings had to wait for them to finish so that they could in tum provide financial support for them, after they had finished their studies. As far as Gottfredson (1981) is concemed, selfconcept compromises many elements including, social class background - which is determined by the family financial status and affordability.

\section{- Career pays well}

The respondents described "careers that pay well" as very influential in choosing a career. The respondents said that they wanted to have jobs that would pay them well, so that they could be 
able to live good lives, lives that would afford them cars and a houses in upper class residential areas. The range of acceptable occupations is termed the social space, which reflects where peple want to fit in society (Greenhaus, 1996; Patton and McMahon, 1999). Some said that they wanted to live better lives than those of their parents. This is contrary to findings by Rojewski and Young (1997) and Furlong and Cartmel (1995), who found that, lower economic status was associated with lowered expectations. The majority of the respondents in this study are from lower to middle income families and therefore it can be arguably inferred that a similar development was unlikely in this case.

\section{$\underline{\text { Parent's educational level }}$}

Parent's educational levels were investigated as a contributory factor in career decision-making. Young and Friesen (1992) found that parents have a strong and acrive role in influencing children's career choices. Major factors in parental influence were responsibility, autonomy, support, communication, encouragement, direcrion and guidance. It is shown in Table 5.14, that the majority of respondents' $\{40 \%$ (24\% males and $16 \%$ females) $\}$ fathers have standard ten and above. Table 5.15 reflects that the majority $\{46 \%$ (25\% males and $21 \%$ females $)\}$ of the respondents' mothers have standard ten and above. Tables 5.16 points out that $32 \%$ of the respondents have guardians where $12 \%$ ( $8 \%$ females and $5 \%$ males $)$ of respondents indicated that their guardians had standard ten and above, and $10 \%$ (6\% males and $4 \%$ females) indicated their guardians have standard six and below. The majority $54 \%$ (33\% being male) of respondents said their parent/guardian level of education influenced their career choice. Most of the respondents expressed their desire to achieve higher education than their parents. The respondents also said that, the higher the education of parents, the more open-minded they are likely to be regarding the career development and career needs of their children.

\section{$\underline{\text { Mother's influence }}$}

Table 5.19 and 5.20: When the respondents were asked, who had the most influence in their choice of carcer between their parents, the majority said that their mothers had the most influence. Although the majority of the respondents live with both parents, it is noted that a large number of them are from the single parent homes where mothers are the heads of the household. Most respondents indicated that their mothers showed interest and were more actively involved in their career development and in suggesting to them which careers were 
more suitable for them. The majority also said that they feel more comfortable discussing career choice issues with their mothers than their fathers (those from families with both parents.

\section{Subject choice}

The subjects chosen at high school were also regarded as influencial factors in the career choices of the majority of the respondents in this study. The respondents felt that it was very important to know at an early stage what career a student wants to follow so that they can choose subjects accordingly during their high school years. Some said that they were disappointed when they discovered that the careers that they had always wanted to do during their school years, required certain subjects that they did not choose at high school, which resulted in them doing second choice courses and in some cases, totally different careers than what they had in mind.

\section{Matric points}

Another factor that was investigated was the influence of matric points on the career decisionmaking process. Matric points were an important influencing factor in the career choice process. The majority of students said that the number of matric points obtained determined which course they were to follow. Some of the respondents said that they had to change from their first choice courses to second choice courses because they did not meet the required points for their first choice courses. Others indicated that they could have attended university had it not been for their low points received in matric.

\section{Important information influencing carcer choice}

A significant number (see Table 5.36-5.41) of respondents in this study felt that it was very important to have information regarding the following:

$\checkmark$ information about yourself

$\checkmark$ information about careers

$\checkmark$ information about admission criteria 


\section{$\checkmark \quad$ information about job opportunities}

\section{$\checkmark$ information about finance}

The respondents said that if they had sufficient information regarding all of the factors above, at an carlier stage and time than they did in their lives, they would have chosen their careers with more enthusiasm and confidence. The above influencers, according to I.indhard (1987), could be prevented provided adequate career counseling and guidance programmes are implemented in schools.

\section{Problematic factors experienced}

The respondents indicate that they experienced some difficulties when they were making their career choices. Some of the contributing factors towards their difficulies in choosing their careers were described as follows:

\footnotetext{
$\checkmark$ Having many possibilities from which to choose (acceptance at various institutions)

$\checkmark$ Lack of or insufficient information (regarding careers, admission, courses)

$\checkmark \quad$ Uncertainty about financial support

$\checkmark$ Pressure from friends (wanting to do same courses and attend same institution)

$\checkmark$ Poor results than those required for admission and possibility of failure

$\checkmark$ Admission by many different institution and not knowing which one to choose
}

Summary of influential factors by total sample (from most to least influential)

The majority of respondents in this study indicated that the two most influential factors in their choice of careers were "finance" and "matric results". Second was "careers that pay well", Third was "media", Fourth was "school subjects", Fifth was "interests and hobbies", sixth was "research into the occupation", Seventh was "parent/guardian's occupation", Eigth was "teacher's influence", Nineth was "influence of friends", Tenth for "community's influence", Eleventh was "part-time job experience" and $8 \%$ twelfth "counseling by current institution".

In view of the above influencers it can be concluded, as Patton and MacMahon (1999) have indicated, that influences representing the social system include peers, family, media, the work place and education system; and that each of these social structures is also the source of values beliefs, and atritudes that may be conveyed to the individual in different ways. Other environmental/socictal influencers which include socioeconomic status and the employment 
market, have featured in this section and clearly their influences can be profound, and, many of them have been highlighted in the work of a number of career theorists (for example: lent, Brown \& Hackett, 1994; Mitchell and Krumboltz, 1990; Roe \& Lunneborg, 1990).

\subsubsection{Influence of guidance at high school}

When the respondents were asked whether their last high school that they attended, had a guidance programme, $62 \%$ (31\% males and 31\% females) indicated that their schools had guidance programmes. This was a great shift from what many studies had found in the past, for example, a number of studies in the last decade indicated a need for career guidance (e.g. Mtolo, 1996; Ntshangase, 1995; Skuy, Hoar, Oakley-Smith \& Westaway, 1985). When the respondents (those who had guidance at school) were asked if their school guidance programme influenced them, the majority said that their school guidance indeed influenced them. Tables 5.27 and 5.28 show us that a significant percentage of the respondents felt that their school guidance prograrmmes were very effective.

On the other hand $38 \%$ (19\% males and 19\% females) said their schools did not have guidance programmes. The respondents that did not have guidance at their high schools were represented by a significant number of respondents from the total sample, even though they did not constitute the views of the majority of the sample population. This reflection has been underlined by a number of studies in the last decade (e.g. Mtolo, 1996; Ntshangase, 1995; Skuy, Hoar, Oakley-Smith \& Westaway, 1985), where learners have pleaded for career education in secondary schools. Unfortunately, as Akhurst and Mkhize (Stead \& Watson, p. 161) attest, factors pertaining to financial constraints in education have severely hindered the provision of carecr education in South Africa. This will be further elucidated in section 6.2.5 (See 6.2.5.2).

\subsubsection{Influence of guidance by current institution}

The majority of the respondents indicated that they did not receive any career counseling from the current institution before enrolling. Some of the reasons the respondents gave, for not getting any career counseling, included statements such as "1 did not know about student counseling, I thought we had to pay". Some suggested that they did not want to seem stupid in a tertiary environment and therefore to ask for help would have made them seem stupid. Others felt that they had sufficient knowledge of what they wanted to do. According to 
Kekana (2003, p.2), lack of career guidance and counseling has resulted in a number of problems that include: poor academic performance; wrong career choices; high failure and drop-out rates; and, moving from one course to the other at tertiary institutions.

For those that received counseling from the technikon, the majority $\{25 \%$ (14\% males and $11 \%$ females) $\}$ indicated that indeed the career counseling from the technikon influenced their decision, while $6 \%$ (5\% females and 1\% males) indicated "no". See 6.2.5.3 for further information.

\subsubsection{Summary of the answers to the study's critical questions:}

\subsubsection{Critical Questions One: What are the social, educational and personal factors that influenced their career choices?}

Although several factors influenced the career choices of this subject sample, the main factors (dominant factors) were: finance, parent/guardians education level, mothers, subject choice, maric points and media.

Other factors - even though these factors did not reflect the views of the majority from the total sample, they however, represented many of the respondents views, these included: ineffective or lack of guidance programme at school, whom you live with, who pays for your studies, parent/guardians, gender, career pays well, interests and hobbies, teacher's influence, influence of friends, research into the occupation and media.

Self-awareness is the cornerstone of effective career decision-making. The majority of the participants in this study were in total agreement that information about themselves, careers, employers, admission criteria (requirements), job opportunities, and information about finance was necessary in order to implement career decisions.

A significant percentage of the subject sample attributed factors such as insufficient information, many possibilities to choose from, confusion as to what to do, admission at various institutions, pressure from friends, results not being good enough, and uncertainty about sponsor for studies / or lack of financial support, to be some of the major obstacles or 
barriers they faced when they were contemplating or at the time they were making a career decision.

Analysis from the interviews and open-ended questions revealed that different learners are influenced by different factors, however, learners from previously disadvantaged schools appear to have less defined career goals. It was also revealed that many respondents experienced some difficulties in integrating their personal information with the occupational information, often resulting in a poor match between their values, interests, personality, and abilities and also with regards to their choice of careers. It was also noted that learners from previously disadvantaged schools seemed to have less occupational information at their disposal, and also appeared to have insufficient information about specific careers of interest to make adequate choices.

Having said the above, it could be that all learners are influenced by all these factors (not only leamers from previously disadvantaged schools) - making it more a factor of their developmental stage and perceived economic precariousness of the South African labour market, than where they were educated. It is, however, the view of the researcher of this study, that these factors are more common factors with learners from previously disadvantaged schools than in any other schools.

\subsubsection{Critical Questions Two: Do they consider the guidance programme of their previous high school as effective?}

Most $(62 \%)$ of the schools from which the respondents were studying, had some forn of guidance programme. Only about thirty-eight percent of respondents came from schools that did not have a career guidance programme at all. It is still a significant number of individuals to go without guidance, especially when considering the fact that it is regulated as a right for them to have such a programme in their schools.

From the $62 \%$ (those from schools that had guidance programme) of the total sample, the majority of about fourty-nine percent, felt that the guidance programme at their schools were effective, while only five percent felt that the programmes at their schools were not 
effective. The rest, which is about eight percent, did not respond to whether or not their school's programme were effective.

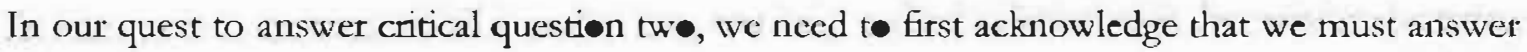
this question in a tw $\bullet$-fold manner:

1. with reference to the total sample, including those that did not have guidance programme in their schools - in this regard, those that did not bave guidancve programme in their schools will automatically fall with those that found guidance in their schools not effective

2. with reference to only those that had guidance programme in their schools - in this regard, those that did not have guidance programme in their school will not be considered

In terms of the above two regards, it can be concluded from the findings in this research, that the answer to critical question two in terms of regard one, the answer is: yes the majority of respondents considered the guidance programme at their previous high school to be effective.

In terms of regard two, the answer is: yes the majority of respondents considered the guidance programme at their previous high school to be effective.

Contrary to the above two regards, the open-ended responses and the interviews, revealed that the primary factors that impact on the difficulties of students from previously disadvantaged schools are the lack of adequate career guidance in high schools. It appears as though there is a severe shortage of career guidance taking place in most schools, but particularly the previously disadvantaged schøols.

6.2.5.3 Critical Questions Three: What role does the student counseling and development centre in their current institution play, in aiding the first year students and prospective students?

The Durban Institute of Technology has a Student Counselling and Development Cence and Career Resource Centre, both commited to assisting prospecrive students (learners) in successfully negotiating their carcer decisions. This is done in a number of ways, including: 
- free individual carecr counseling to all prospective students (learners)

- free access to a fully developed and stocked Career Resource Centre, which offers critical career information, as well as information on the courses offered by DIT and other tertiary institutions.

- conducting of free career presentations at schools, career exhibitions, and career fairs

- formal career assessments at a small fee

Registered students at DIT are given support in a number of ways. These include:

ongoing career counseling

$>$ ongoing academic support, both via Student Counseling and Development Centre (i.e. Study Skills programmes)

$\checkmark$ ongoing therapy and personal support via Student Counseling and Development Centre - where appropriate.

> bridging courses for learners who do not meet the English requirements, in which they are given additional English tuition (known as the NCC)

ongoing financial advise and financial assistance

Upon exploring the degree to which students utilized these resources it was noted from the sample in this research that the majority $(71 \%)$ did not utilize these crucial resources that were set up to accommodate them. Among their reasons were, lack of knowledge about such resources, lack of finance to travel to these institutions, perceptions related to status of those acceptable within these institutions premises etc. It was also reflected, however, that from the twenty-nine percent who received counseling $86 \%$ indicated that the counseling they received influenced their choices. The indication as it appears from the interviews analysis, were that the effort by the institution appeared to be extremely effective, judging by the regularity with which the CRC is booked for presentations, and the feedback received from various activities.

\subsection{CONCLUSION}

The purpose of this study was to explore the factors impacting on career choices of first year technikon students from previously disadvantaged high schools. Various factors were found to have influenced the career choices of the participants under this study, where the most dominant factors were identified to be finance and parent/guardians education level; other factors such as mother's influence, subject choice, matric points/ results, poor English and media were also identified as having an influence in their career choices. It was further revealed 
by the sample in this research that factors such as insufficient information, many possibilities to choose from, confusion as to what to do, admission at various institutions, pressure from friends, results not being good enough, and uncertainty about sponsor for studies /or lack of financial support, attributed to be some of the major obstacles or barriers that these students ate faced with when making a career choice.

Some of these factors may appear to be insignificant, resulting in them being taken lightly, however, they have very negative implications for the students, parents and tertiary institutions. For example, a factor such as poor English can have the following implications: those students who are accepted into the course, but still battle with English comprehension, have greater difficulty understanding the academic matcrial, and mastering written assignments and verbal presentations. This results in an increased failure rate, which adversely impact both the student and the institution.

The poorly articulated career goals result in students failing te succeed in their chosen courses, either because they don't enjoy the course or don't have an aptitude for it (or both). This also results in high failure rates and, depending on the extent of the failure, can result in students being excluded from re-enrolling. This has potentially devastating effects, particularly on the affected students. Poorly articulated goals may also result in unnecessary changes of courses. Since cach course is specialized to that career, such changes can result in students essentially starting a ncw course from scratch - which results in an additional financial burden being on the student and their family. With adequate guidance programmes in schools (not just at Grade 12), such problems could be prevented.

It ought to be reiterated also, that guidance and counseling is important for African pupils, particularly Søuth Africans, as an integral component of quality education. The limited extent to which guidance and counseling are included in the school curriculum of some of the African schools, clearly indicates the deprivation of our pupils on oppornunities of becoming better men and women in their future life. The school counselor's interests are in the development of the whole person. For this reason, the focus of guidance goes beyond addressing educational problems that pupils experience and includes personal, social and vocational issues. Such an approach conkibutes to pupils' personality development and their potential to experience a more meaningful, fulfilling and prosperous life. 
This rescarch acknowledges the view that, it will take a while before guidance and counseling is made available and accessible in all African schools. But, we need not wait until this happens. Teachers who have had access to psychology, educational psychology and other behavioural science courses can play the role of counselor in addition to their teaching responsibilities. This may serve as short-term solution while the problem is addressed more thoroughly" (Mwamwenda, 1996: 473 - 474).

Having identified the factors that influenced students from the previously disadvantaged sector, Africans in particular, one cannot help but wonder if all leamers are influenced by these factors - making it more a factor of their developmental stage and perceived economic precariousness of the South $\Lambda$ frican labour market, than where they were educated. Still, it is the researcher's view, that these factors are more common with learners from previously disadvantaged schools. Perhaps the difference between learners from previously disadvantaged schools and other learners is the degtee to which these factors influence their decisions (far more prevalent in the former than the latter).

The results of this research, however, indicate a slight shift in the dissatisfaction about the availability and effectiveness of the guidance programmes in the previously disadvantaged, when compared to other studies conducted in the earlier parts of South Africa's post apartheid era, this area however, is still a cause of great concern, as reflected in this chapter's section 1 that thirty-eight percent of respondents came from schools that did not have career guidance at all. There is also a seemingly greater shift in terms of gender being the influencial factor in choosing a career, there appears to be a greater awareness that more opportunities exist in all facets of the labour market for females, an indication of a slight shift from traditional career choices in the South A frican labour market.

The results of this particular investigation may conwibute to the literature in several ways. This information can be used to improve theoretical explanations, guidance and counseling activities, the development and sequencing of academic and career courses and programmes and ransition planning efforts for adolescents and young adults. These results may also conwibute to the pootly researched area of career development in the South African context, and perhaps add to the emerging data contributed by other researchers in this area. 


\subsection{RECOMMENDATION}

This section deals with the recommendations that are suggested at two levels, for further research and, career counseling and development in schools and tertiary institutions.

For further research:

1. Further research, of a comparative nature, is required in order to determine the extent to which differences exist between the learners from previously disadvantaged schools and those from other schools with regards to career choice problems in South African Schools.

2. An intense study of careers resource availability in the previously disadvantaged schools could provide useful information regarding the extent to which these schools lack resourceful materials and centers.

3. A potentially useful and resourceful research area for local career theories would be to test the appropriateness of specific theoretical models to the South African context, especially the previously disadvantaged sector.

For under-resourced previously disadvantaged schools and communities:

4. The schools need to develop Career Resource Centres, no matter how modest, and have dedicated programmes catening to the career development of leamers at critical stages of career development (not just at Grade 12). Leamers should be exposed to different types of careers through literature, and presentations, etc. The schools could make use of the skills of the community for such presentations - which therefore do not have to be costly (i.e. parents talking about their occupations).

5. One way that some disadvantaged communities have successfully addressed this issue is by getting committed and interested members of the community to assist in setting up Career Resource Cenres (i.e. previous leamers). Also these Career Resource Centres do not necessarily have to be attached to individual schools, but can be shared amongst schools located close to one another. The school can also seek sponsorship (from local businessman and prominent community figures) to assist in the costs of setting up such a centre. The schools can also access the resources that are freely available, such as the 
Community Liaison Activities of tertiary institutions, in which career-related presentations are conducted for learners.

6. Assistance in respect of career guidance, information on admission policies, registration procedures, financial assistance, academic support, and availability of other support services should be provided for individuals in the previously disadvantaged schools. All growing individuals need ongoing assistance from parents, teachers, and guidance personnel to develop their understanding of the world of work, differences between the work and school environment, individual strengths and weaknesses, ways to maximize strengths and minimize weaknesses and short and long-term goals.

For career guidance educators:

7. Career counselors/ guidance teachers need to move away from the individualistic perspective toward career development. A narrow focus on personal attributes should be broadened to an awareness of the external constraints that impact on career development. The holistic approach will assist leamers in tailoning their career choices to labour market and circumstantial realities.

For Department of Education and Culture:

8. Policy makers must take into account the extent to which financial constraints impact on career choices of youth in the counry, and take measures to address this issue.

9. The DEC necds to put more pressure on principals, teachers and career educators in schools, especially those in the previously disadvantaged sector of the South African population, to develop more effective means of addressing career related problems faced by learners, more especially in the township and rural schools. 'They could arrange to meet and visit other school that have effective and programmes and learn from them.

For learners at schools:

10. Students nced to play an active role in their own career development. They should be encouraged to seek information independently, without the teachers pushing them all the 
time. They can also benefit greatly from the resources such as the internet and, from visiting tertiary institutions and utilizing the resources that are available.

For tertiary inswitutions:

11. The Student Counseling and Development Centres and Career Resource Centres in tertiany instutions need to market themselves much more rigorously.

12. Tertiary institutions need to ensure that they conduct pre-registration (departmental) orientation programmes, where students are given a much more realistic view of what they should expect from their chosen courses, for all those who are accepted as furst year students.

13. The purpose of the Cental Applications Office (CAO) needs to be clearly articulated as it often confuses students.

\subsection{LIMITATIONS TO THE STUDY}

This section focuses its attention on possible limitations. The limitaions were perceived to be lying in the following areas:

1. The findings of this study are limited to a particular sample which has some common characteristics. Caution should therefore be exercised when attempting to generalize the findings to the greater $1^{\text {st }}$ year technikon students from previously disadvantaged schools in the country. The total sample population in this study consisted of a targeted sample, in which the majority were Africans, the majority of which were Zulu speaking

2. The questionnaire yielded more data than was necessary to answer the crivical questions of the study.

3. The majority of the sample population were second English language speakers. The questionnaire was constructed and administered in the English language. Some questions appeared to have posed problems for the mostly $2^{\text {nd }}$ language speakers and may have impacted on the expressions of their responses to questions regarding factors impacting on their career choices. 
4. The questionnaire seemed to be long, even though the necessary modifications were made before the final instrument was thoroughly validated.

5. Although it was desirable, it was not possible to explore all the factors that influenced career choice of individuals from previously disadvantaged high schools, given the scope and depth of this study. 


\section{REFERENCES:}

Akhurst, J., \& Mkhizc, N.J. (1999). Career Education in South Africa. In G.B. Stead \& Watson (Eds.), Career Psychology in the South African Context (pp. 163-179). Pretoria: J.L. van Schaik.

Arthur, M.B., Hall, D.T., \& Lawrence, B.S. (1989). Handbook of Career Theory. Cambridge, U.K: Cambridge University Press.

Baijnath, P. (2003). Med Dissertation: The Occupational Choices Of Ex-Grade 12 Learners At a Special Needs School Between 1996-2001. Unpublished Masters 'Thesis: UDW, Durban.

Bandura, A. (1977). Self-Efficacy: Towards a Unifying Theory of Behavioural change. Psychological Rerriew, 84, 191-215.

Beerlall, S. (1997). Career Decision Making: The Relationship Between Educational Indecision and vocational Indecision. Unpublished Masters Thesis: UDW, Durban.

Behr, A.L. (1973). Methods and Techniques in Educational and Psychological Research. Prctoria: J. L. Van Schaik Ltd.

Bhamjee, E.M. (2001). Med Dissertation: Career Aspirations of Grade Eleven Learners. Unpublished Masters 'Thesis: UDW, Durban.

Bojuwoye, O. (2002). Stressful experiences of first year students of selected Universities in South Africa. Counselling Psychology Quartely, 2002, Vol. 15, No. 3, pp. 277-290. BrunnerRoutledge.

Booysen, L. (1999). Male and Female Managers: Gender influences on South African Managers in Retail Banhing. South. African Journal on Labour Relations, 23(2), 25-54. 
Brown, D. (1990). Summary, comparison and Critique of the major theories. In D. Brown \& L. Brooks (Eds.), Career choice and development: Applying contemporary theories to practice, (2 $2^{\text {nd }}$ ed., pp. 338-363). San Fransisco: Jossey-Bass.

Brown, D., \& Brooks, L. (1996). In D. Brown \& L. Brooks (Eds.), Career Choice and Development. ( $3^{\text {rd }}$ ed.). San Fransisco: Jossey-Bass.

Brown, D. \& Brooks, L. (1996b). Introduction to theories of career development and choice. In D. Brown \& L. Brooks (Eds.), Career choice and development: Applying contemporary theories to practice, ( ${ }^{\text {rd }}$ ed., pp. 337-372). San Fransisco: Jossey-Bass.

Cloete, N. (1981). Occupational Orientation of Black Youth in Southem Africa. Psychologia Africana, 20, 53-79.

Cohen, L., \& Manion, L. (1980). Research Methods in Education. London: Groom Helm Ltd.

Corey, G. (1991). Theory and Practice of Counselling and psychotherapy. (4 $4^{\text {th }}$ ed.). Pacific Grove, CA; Brooks/ Cole.

Cozby, P.C. (1981). Methods in Behavioral Research. $2^{\text {nd }}$ ed. Mayfield Press: Carlifornia.

Collin, A., \& Watts, A.G. (1996). The death and transfiguration of career - and of career guidance? British Journal of Guidance and Counselling. 24, 385-398.

Crites, J.O. (1969). Vecational Psycholøgy. New York: McGraw-Hill.

De Bruin, G.P. (1999). Social Cognitive career theory as an explanatory model for career counseling in South Africa. In G. B. Stead and M. B. Watson (Eds.), Career Psychology in the south African Context (pp. 91-102). Pretoria: J. L van Schaik.

Faqua, D.R., \& Harman, B.W. (1983a). Differential Diagnosis and Treatment of Career Indecision. Personnel and Guidance Journal, 62, 27-30. 
Faqua, D.R., \& Hartman, B.W. (1983b). A Behavioural Index of Career Indecision for College Students. Journal of College Student Personnel, 24, 507-512

Figler, H., \& Bolles, R.N. (1999). The Career Counselor's Handbook. Canada: Ten Speed Press.

Freeman, S. (1993). Donald Super: A perspective of career development. Journal of Career Development. 19, 255-264.

Furlong, A., \& Cartmel, F. (1995). Aspirations and Opportunity Structures: 13-year-olds in areas with restricted opportunities. British Jounal of Guidance and Counselling, 23(3), 361-375.

Gibson, I. (2000). Career Indecision - A fact of life for those choosing "non-vocational" degrees? Careers 2000. Pietermaritzburg, KZN, SA: The Natal Witness Prining and publishing Company (Pty) Ltd.

Gottfredson, L.S. (1981). Circumscription and Compromise: A developmental Theory of occupational aspirations (Monograph). Journal of Counselling Psychology, 28, 545-579.

Gottfredson, I..S. (1996). Gottfredson's Theory of Circumscription and Compromise. In D. Brown, L. Brooks, and Associates (Eds.), Career choice and Development (3 ${ }^{\text {rd }}$ ed., pp.179-232). San Fransisco, CA: Josey-Bass.

Greenhaus, J.H. (1996). Career Management. Philadelphia: Harcourt Brace.

Human Sciences Research Council. (1999). Skills Needs of The South African Labour Market: 1998 - 2003, Pretoria: Human Sciences Research Council.

Holland, J.L. (1985). Making Vocational Choices. (2 $2^{\text {nd }}$ ed.). Engelwood Cliffs, N. J. : Prentice-Hall.

Kekana, E. (2003). Med Dissertation: Career Choices of Leamers in Township Schools. Unpublished Masters Thesis: UDW, Durban. 
Ikuenobe, (1998), cited in Kekana, E. (2003). Med Dissertation: Career Choices of Learners in Township Schools. Unpublished Masters Thesis: UDW, Durban.

Krumboltz, J. D. (1992). The Wisdom of Indecision. Journal of Vocational Behaviour, 41, 239-244.

Lincoln, Y.S., \& Guba, E.A. (1985). Naturalistic Inquiry. USA: Sage Publishers.

Lindhard, N. (1987). Guidance in the Classroom. $2^{\text {nd }}$ ed. Maskew Miller Iongman: Cape Town.

Lunneborg, P. W' (1978). Sex and career decision-making styles. Journal of Counselling Psychology, 25, $299-305$.

Maree, K, \& Ebersohn, L. (2002). Life Skills and Career Counselling 2002. Heineman Publishers (Pty) Ltd: Cape Town.

McDaniels, C., \& Gysbers, N. C. (1992). Counselling for career development: Theories, resources and practice. San Fransisco: Josse-Bass.

Miller, M. J. (1983). The role of happenstance in career choice. The Vocational Guidance Quartely. 32, 16-20.

Mitchell, L. K. \& Krumbolts, J. D. (1990). Social Learning approach to career decision-making: Krumboltz's theory. In D. Brown \& L. Brooks (Eds.), Career choice and development: Applying contemporary theories to practice, (2 ${ }^{\text {nd }}$ ed., pp. 145-196). San Fransisco: JosseyBass.

Mwamwenda, T. S. (1995). Educational Psychology: An African Perspective. (2 $2^{\text {nd }}$ Ed.). Durban: Butterwerth Publishers.

Naidoo, R. (2000). A study of the Occupational Choices of Women in South Africa. Paper Presented at the $21^{\text {st }}$ Annual Conference of the Society for Student Counselling of South Africa, Durban, 3 - 6 October 2000 . 
Papalia, D.E., \& Olds, S.W. (1988). Psychology: International Student Edition. $2^{\text {nd }}$ ed. McGraw-Hill, Inc: USA.

Patton, M.Q. (1990). Qualitative evaluation and research methods. $2^{\text {nd }}$ ed. Newbury Park: Sage Publications.

Patton, W., \& McMahon, M. (1999). Career Development and Systems Theory. A New Relationship. Johannesburg: Brøoks/ Cole Publishing Company.

Polkinghorne, D. E. (1990). Action theory approaches to career research. In R. A. Young \& W. A. Borgen (Eds.), Methodological approaches to career Research (pp. 87-105). New York: Pracger.

Pretorius, C. (2003). A hunch of F's will get you through matric. Sunday Times. Gauteng, South A frica: Argus Press.

Pryor, R.G.L, \& Taylor, N.B. (1989). Circumscription and Compromise: Some problems and some possibilities. Austrulian Psychologist, 24 (1), 101 - 113

Punch, F.K. (2000)). Developing Effective Research Proposals. SAGE Publications: Londen.

Richardson, M. S. (1996). From career counseling to counseling/ psychotherapyand work, jobs and career. In M. L. Savickas \& W. B. Walsh (E.ds.), Handbook of Career counseling, theory and practice (pp. 347-360). Pale Alto, CA: Davies Black.

Richardson, M. S. (1993). Work in people's lives: A location for Counselling Psychologists. Journal of Counselling Psyibology. 40, 425-433.

Rojewski, J. W., \& Yang, B. (1997). Longitudinal Analysis of Select Influences on Adolescents' Occupational Aspirations. Joumal of Vocational Behainour, 51, 375-410.

Salomone, P. R. (1982). Difficult Cases in Career Counselling: II The Indecisive Client. The Personnel and Guidance Journal, 60, 496-500. 
Sdorow, L.M. (1993). Psychology. $2^{\text {nd }}$ ed. Brown \& Benchmark, Publishers: U.S.A.

Sekeran, U. (1992). Research Methods for Business: A Skill Building Approach. $2^{\text {nd }}$ ed. John Willey \& Sons Inc: New York.

Singh, (1991). Cited in Kekane, E. (2003). Med Dissertation: Career Choices of Learners in Township Schools. Unpublished Masters 'Thesis: UDW, Durban.

South Africa (Republic). National Education Policy Act, of 1967, Pretoria, Govemment Printer.

Spokane, A. R. (1996). Holland's 'Theory. In D. Brown \& L. Brooks (Eds.), Career Choice and Development. ( $3^{\text {rd }}$ ed., pp. 33-74). San Fransisco: Jossey-Bass.

Statistics South Africa (2000). Stats in Brief 2000. Pretoria: Statistics South $\Lambda$ frica.

Stead, G.B., Foxcroft, C.D., \& Watson, M.B. (1991). Factor Analysis of the Career Decision Scale on South African high school students. Psychological Reports, 69, 1083 - 1088.

Stead, G.B., \& Watson, M.B. (1998). Career Psychology: in Søuth African Context. J.I .. van Schaik Publishers: P'retoria.

Stead, G.B., \& Watson, M.B. (1999). Career Psychology: in the South African Context. J.L. van Schaik Publishers: Pretoria.

Stevens, G., \& Lockhat, R. (1997). "Coca Cola kids" - reflections on black adolescent identity development in post apartheid South Africa. South African Joumal of Psychology, 27 (4), 250-255.

Supcr, D. E. (1992). Towards a comprehensive theory of career development. In D.H. Monmoss \& C.J. Shrinkman (Eds.), Career development: Theory and practice (pp. 35-64). Springficld, I.L.; Charles C. Thomas. 
Super, D. E., Savickas, M. L., \& Super C. M. (1996). The life span, life-space approach to careers. In D. Brown \& L. Brooks (Eds.), Career Choice and Development. ( $3^{\text {rl }}$ ed., pp. 121-178). San Fransisco: Jossey-Bass.

'Tiedeman, D.V., \& O'Hara, R. P. (1963). Career Development: Choice and Adjustment. New York: College Entrance Examination Board.

Vaughan, (1970). Cited in Kekane's Med Dissertation: Career Choices of Learners in Township Schools. Unpublished Masters 'Thesis: UIDW, Durban.

Van Vuuren, S. J. (1991). An educational case study assisting a technikon student with Career Decision Making Skills. Unpublished master's thesis, University of Natal.

Watson, M.B., \& Allan, M.M. (1989). Work Role Salience: comparison of students in career-directed and general degree courses. Psychological Reponts, 64, 699-704.

Watson, S. B., Foxcroft, C. D., \& Stead, G. B. (1991). Factor Analysis of the Career Decision Scale on the South African high school students. Psychological Reports, 69, 1083 1088 .

Young, R. A., \& Friesen, J. D. (1992). The intentions of parents in influencing the career development of their children. Career Development Quartely, 40, 198-207

Zunkcr, V. G. (1994). Using assessment results for carcer development.(4 ${ }^{\text {th }}$ ed.). Pacific Grove, CA: Brooks/ Cole.

Zunker, V. G. (1998). Carcer $5^{\text {th }}$ Counselling: Applied concepts of life planning. (5 $5^{\text {th }}$ ed.). Pacific Grove, CA: Brooks/ Cole. 


\section{SURVEY ON CAREER CHOICES}

\begin{tabular}{|l|l|}
\hline RESEARCHER & MR S. N. MBANJWA \\
& Reg. NO. 200201899 \\
\hline SUPERVISOR & \begin{tabular}{l} 
PROF. O. BOJUWOYE \\
\hline PURPOSE
\end{tabular} \\
$\begin{array}{l}\text { TO INVESTIGATE THE EACTORS } \\
\text { IMPACTING ON CAREER CHOICES } \\
\text { OE DIT 1 ST YEAR TECHNIKON } \\
\text { STUDENTS FROM PREVIOUSLY } \\
\text { DISADVANTAGED HIGH SCHOOLS. }\end{array}$ \\
\hline
\end{tabular}

I understand that:

- Participation in this study is voluntary

- I may withdraw from this sludy at any time

- I may refuse to answer any of the questions

- There will be a maximum of two interviews

- The interviews will be tape recorded and transcribed for ease of analysis

- Confidentiality will be strictly respected

I consent to participate in this study.

Signature

Date 


\section{SURVEY ON CAREER CHOICES}

The purpose of this survey is to determine the factors impacting on career choices of $1^{\text {th }}$ year technikon students from previously disadvantaged high schools. The information will be used solely for the purpose of this research and information from this survey will be used to help schools and policy-makers to consider these factors and therefore identify more effective programmes for their learners.

PLEASE CROSS (X) APPROPRIATE BOXES WHERE APPLICABLE.

1. BIOGRAPHICAL DETAILS

\subsection{Age (at last birthday)}

\begin{tabular}{|l|l|l|l|l|l|l|l|}
\hline 19 urs. & 20 vrs. \\
\hline
\end{tabular}

1.2 Sex/ Gender

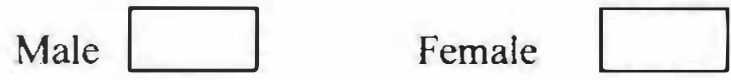

1.3 Population Group

\begin{tabular}{|l|l|}
\hline African & Indian \\
\hline
\end{tabular}

1.4 Marital Status
Sinale
Married
Other:

1.5 Mother Tongue

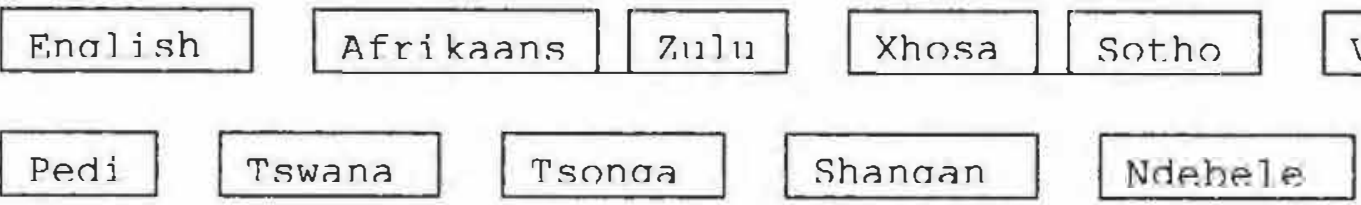




\section{FAMILIAL FACTORS}

2.1 a) Whom do you live with?

\begin{tabular}{|c|c|c|c|c|}
\hline Both & mother & father & aluardian & Other (pleas \\
\hline
\end{tabular}

b) Does who you live with influence your career choice?

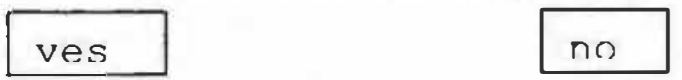

2.2 a) What is the approximate family income?

\begin{tabular}{|c|c|c|c|c|}
\hline$<\mathrm{R} 1000$ & $\mathrm{R} 1-3000$ & $R 3-5000$ & $R 5-7000$ & $R 7000 \&>$ \\
\hline
\end{tabular}

b) Did your family income influence your career choice?

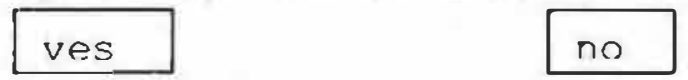

2.3 a) Who is paying for your studies?

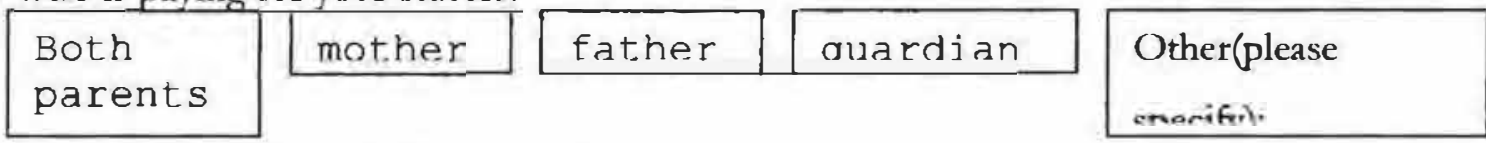

b) Did that influence your career choice?

ves

\section{no}

2.4 Parent/Guardian's age profile

\begin{tabular}{|l|l|l|l|}
\hline$A G E$ & FATHER & MOTHER & GUARDIAN \\
\hline $30-40$ yrs & & & \\
\hline $40-50 y \mathrm{rs}$ & & & \\
\hline $50-60$ yrs & & & \\
\hline $60+$ & & & \\
\hline
\end{tabular}

2.5 a) Parent/Guardian's level of education:

FATHER:

$$
\text { St.d. } 10 \text { \& above }
$$

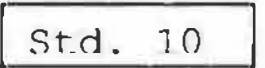

$$
\text { Std. } 6
$$

Below st.d. 6

MOTHER: Std. 10 \& above

std. 10

$$
\text { st.d. } 6
$$

Below st.d. 6

GUARDIAN:

$$
\text { Std. } 10 \text { \& above }
$$

\section{std. 10}

\section{St.d. 6}

Below std. 6

b) Did your parents level of education influence your choice?

$$
\text { ves }
$$

$$
\text { no }
$$

2.6 What is the occupation of your,

Father: Mother: Guardian:

2.7 Did your parents/guardian have any influence in the choice of your career?

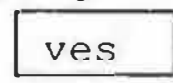

$$
\text { no }
$$

2.8 Who influenced your career choice the most?

\begin{tabular}{|l|l|l|l|}
\hline father & mother & ouardian \\
\hline
\end{tabular}




\section{EDUCATIONAL FACTORS}

3.1 Did the subjects you studied for the Senior Certificate influence your career choicc? [ves]

no

3.2 Did the number of matric points you obrained determine which course you were to follow?

ves

no

3.3 a) Did the school where you did your grade 12 have a career guidance programme?

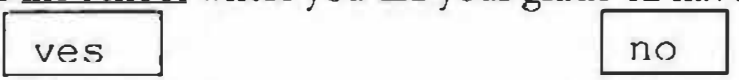

b) If yes, did it influence your choice of career?

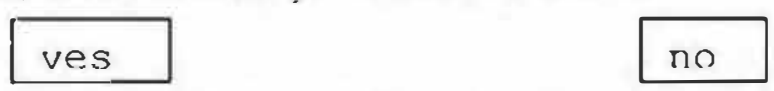

c) If yes, how would you rate the program using the following ratings:

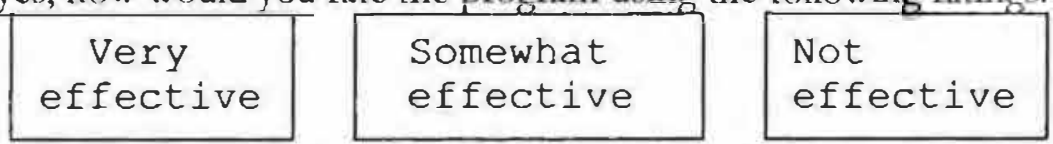

3.4 a) Did you get any career counseling from the technikon's student counseling centre before choosing your current course?

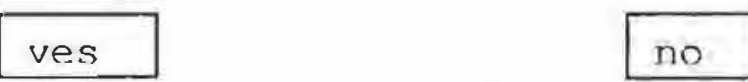

b) If yes, did it influence your career choice decision?

$$
\text { ves }
$$

no

3.5 What career did you choose?

\section{INDIVIDUAL AND PSYCHO-SOCIAL FACTORS}

4.1 How certain are you that your career choice is the correct one?

\begin{tabular}{|l|l|l|l|}
\hline Very certain & $\begin{array}{l}\text { A little } \\
\text { uncertain }\end{array}$ \\
\hline
\end{tabular}

Not at all certain

4.2 Did your gender influence the choice of your career?

ves

$$
\text { no }
$$

4.3 Have any of the factors (a-m) below influenced your career choice? (PIease circle each one)
a) Finance i.e low family income
b) Parent/Guardian's occupation
c) 'Teacher's influence
d) Influence of friends
e) Your matric results 
f) Your community's influence

g) Your school subjects and experience at school

h) Your interests and hobbies

i) Part-time job experiences

i) Research into the occupation

k) Career pays well

1) Counseling by current institution

m) Media, as in radio, television, newspaper or magazine

n) Other factor (please specify)

$4.3 \mathrm{~b}$ ) What was the single most influential factor in choosing your carcer? Choose enly one between a) and $\mathrm{m}$ ) above (Please put a cross on one letter only)

\begin{tabular}{|l|l|l|l|l|l|l|l|l|l|l|l|l|}
\hline a) & b) & c) & d) & e) & f) & g) & h) & i) & i) & k) & l) & m) \\
\hline
\end{tabular}

4.4 When contemplating on your career choice did you have: (please circle those applicable to you)

a) enough information

b) many possibilities to choese from

c) confusion as to what to do

d) admission at various institutions

e) pressure from friends

f) results were not good enough

g) Unsure about sponsor for studies/ lack financial support

h) Other reasons (please specify)

4.5 In your opinion, how important are the following influencers (a-f) in career decisionmaking? (please tick the appropriate column)

\begin{tabular}{|l|l|l|l|}
\hline & (1)Very Important & $\begin{array}{l}\text { (2) } \\
\text { Important }\end{array}$ & $\begin{array}{l}\text { (3)Not } \\
\text { important }\end{array}$ \\
\hline a)information about yourself & & & \\
\hline b)information about careers & & & \\
\hline c)imformation about employers & & & \\
\hline d)admission criteria (requirements) & & & \\
\hline e)information about job opportunities & & & \\
\hline f)information about finance & & & \\
\hline
\end{tabular}

4.6 Did the choice of subjects at school determine totally or partially what you were going to study at the technikon. (Please explain)

4.7 a) Is you current career, the one you originally wanted to follow?

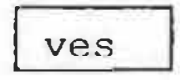

$$
\text { no }
$$

b) If no, what prevented you from choosing the career you wanted to follow originally? 
4.8 What steps did you take to come to your decision and who are the people you consulted along the way?

4.9) Did your cultural background or values influence your choice of career? Please describe how?

4.10 Did the expectations of your community influence the choice of your career? Please explain how?

4.11 a) Do you think that factors such as cultural group, gender, and physical characteristics (such as physical handicaps) have an influence on career choice?

b) How did it influence you?

4.12 Did you choose your career by chance? Chance, meaning by accident or good luck.

$$
\text { ves }
$$

4.13 What were the problems you encountered in making your career choice? (Please explain)

1.

2.

3.

4.14 Is there any other additional information you would like to share?

\section{Thank you for your co-operation!}

